\title{
ACCOUNTABILITY FINANCEIRA E ORÇAMENTÁRIA NO BRASIL
}

\author{
O conceito e a instituiçãa da auditoria são inerentes à \\ administração financeira do Estado, pois a gestão de recursos \\ públicos envolve uma relação de confiança. A auditoria não é \\ um fim em si mesma, mas um elemento indispensável de \\ um sistema cujo objetivo é revelar desvios dos padróes aceitos \\ e violaçôes dos principios de legalidade, eficiência, \\ eficácia, efetividade e economicidade na gestão \\ financeira e orçamentária [...]. \\ (Declaração de Lima, 1977) ${ }^{191}$
}

Em qualquer país democrático e republicano, é de se esperar que os governantes, todos eles, sejam obrigados a conduzir os negócios do Estado com a finalidade de atender às necessidades públicas ${ }^{192}$. Para satisfazê-las, como explicam António L. de Sousa Franco ${ }^{193}$ e João Ricardo Catarino ${ }^{194}$, as entidades públicas precisam afetar bens e recursos ${ }^{195}$. Para os obter, os entes públicos exploram seu patrimônio, impõem tributos

191 INTERNATIONAL ORGANIZATION OF SUPREME AUDIT INSTITUTIONS (INTOSAI). INTOSAI Principles. INTOSAI Founding Principles. INTOSAI-P 1: The Lima declaration. Lima: INTOSAI, 1977. Disponível em: https://www.issai.org/pronouncements/intosai-p-1-the-lima-declaration/. Acesso em: 17 out. 2019. p. 7 (tradução nossa).

192 A decisão a respeito de quais necessidades devem ser satisfeitas pelo Estado deve ser tomada coletivamente pela sociedade, cf. STIGLITZ, Joseph E. Economics of the public sector. 3. ed. New York: W.W. Norton \& Company, 2000. p. 15. Nos estados democráticos de direito, tal decisão coletiva se dá na constituição, cf. TORRES, Heleno Taveira. Direito constitucional financeiro: teoria da constituição financeira. São Paulo: Revista dos Tribunais, 2014. p. 416.

193 FRANCO, António L. de Sousa. Finanças públicas e direito financeiro. 4. ed., 5. reimpr. Coimbra: Almedina, 1997. p. 3.

194 CATARINO, João Ricardo. Para uma teoria política do tributo. 2. ed. Lisboa: Centro de Estudos Fiscais, 2009. (Cadernos de Ciência e Técnica Fiscal n. 184). p. 187.

195 Como mostram Stephen Holmes e Cass R. Sunstein, todos os direitos, inclusive aqueles tradicionalmente ditos negativos, demandam algum tipo de prestação estatal e, portanto, têm custos. É que, como destaca 


\section{-• Contas dos governantes}

e se endividam, enquanto aplicam os recursos auferidos na consecução das finalidades públicas, na forma definida no orçamento aprovado pelo parlamento. Por isso é que, como adverte Fernando Facury Scaff ${ }^{196}$, é impensável a existência de um Estado sem a correspondente atividade financeira ${ }^{197}$.

Assim, considerando que a atuação governamental envolve tão intensa atividade financeira e que os governantes, como justifica o capítulo 1 (p. 39) deste trabalho, devem se sujeitar à accountability em todos os ramos em que atuem, conclui-se que esta deve se estender à atuação deles na gestão financeira e orçamentária da Administração Pública. Por conseguinte, o conjunto normativo deve obrigar os governantes a apresentar todas as informaçóes e argumentos que evidenciem a correção de suas ações e omissões referentes à imposição de tributos e ao endividamento público, à administração dos recursos auferidos, do patrimônio público e da dívida pública, bem como à realização das despesas públicas, tanto aos eleitores e à sociedade de maneira geral como perante as agências estatais encarregadas de exercer, como sujeitos ativos, a accountability financeira e orçamentária.

No Brasil, o legislador constituinte consagrou a accountability financeira e orçamentária como fundamental, na medida em que exigiu que todo aquele - inclusive os governantes - que, de qualquer modo, manejar recursos públicos, ou equiparados deverá prestar contas de suas açóes e omissóes, como se pode observar no parágrafo único do artigo 70 da CRFB/1988, assim redigido:

CRFB/1988, Art. 70. [...]

Parágrafo único. Prestará contas qualquer pessoa física ou jurídica, pública ou privada, que utilize, arrecade, guarde, gerencie ou administre dinheiros, bens e valores públicos ou pelos quais a União responda, ou que, em nome desta, assuma obrigações de natureza pecuniária ${ }^{198}$.

Observe-se que, por um lado, as contas prestadas atendem à demanda por transparência das decisóes políticas, decorrente das expectativas democráticas, com impacto substancial na eficácia da accountability vertical. Como se vê na subseção 1.5.1 (p. 58)

Flávio Galdino, não há prestação pública gratuita, cf. HOLMES, Stephen; SUNSTEIN, Cass R. The cost of rights: why liberty depends on taxes. New York: W. W. Norton \& Company, 1999. p. 13-83; e GALDINO, Flávio. Introdução à teoria dos custos dos direitos: direitos não nascem em árvores. Rio de Janeiro: Lumen Juris, 2005. p. 346.

196 SCAFF, Fernando Facury. Orçamento republicano e liberdade igual: ensaio sobre direito financeiro, república e direitos fundamentais no Brasil. Belo Horizonte: Fórum, 2018. p. 41.

197 A atividade financeira do Estado compreende "[...] a arrecadação de receitas, orçamento, despesas, controle, partilha federativa e responsabilidade fiscal”, cf. CONTI, José Mauricio. O planejamento orçamentário da Administração Pública no Brasil. 2017. 556 p. Tese (Professor Titular) - Faculdade de Direito, Universidade de São Paulo, São Paulo, 2017. p. 45.

198 BRASIL. Constituição (1988). Constituição da República Federativa do Brasil. Disponível em: http:// www.planalto.gov.br/ccivil_03/Constituicao/Constituicao.htm. Acesso em: 2 dez. 2019. 
deste trabalho, quanto maior o conhecimento sobre a conduta dos representantes, maior a possibilidade de que eles sejam efetivamente responsabilizados pelos eleitores nas urnas, com a manutenção ou retirada de apoio. Por outro lado, ao trazer à luz informações sobre as ações e omissões dos governantes na gestão financeira e orçamentária da Administração Pública, a prestação de contas limita a sua discricionariedade e os inibe de praticar atos que atentem contra o interesse público - inclusive a corrupção -, atendendo agora às exigências republicanas.

O caput do referido artigo $70 \mathrm{da} C R F B / 1988$ deixa expresso que, quando o constituinte se referiu à União, abarcou tanto a administração direta quanto a indireta, e incluiu não somente o Poder Executivo, mas cada poder ou órgão público. Segundo Régis Fernandes de Oliveira ${ }^{199}$, o alcance à administração indireta, além da direta, teria sido uma grande alteração em relação à constituição anterior. Todavia, conquanto a clareza constitucional constitua efetivamente uma novidade, na realidade, como destaca José Mauricio Conti ${ }^{200}$, ainda no ordenamento anterior, a jurisprudência do TCU já incluía entre os obrigados a prestar contas os responsáveis pelos órgãos da administração indireta ${ }^{201}$.

Além disso, embora o dispositivo constitucional se refira especificamente à União, na verdade, ele tem obrigatória aplicação em todas as esferas da Federação. Inclusive, a CRFB/1988 elevou a prestação de contas à categoria de princípio constitucional sensível, conforme se depreende de seus artigos 34, inciso VII, alínea "d" que permite à União tomar a gravíssima medida de intervenção em estado ou no DF, para assegurar a observância do princípio constitucional da prestação de contas da Administração Pública, direta e indireta -, e 35, inciso II - que permite aos estados intervirem nos seus municípios, quando não forem prestadas as contas devidas. Desse modo, tinha razão Hely Lopes Meirelles ${ }^{202}$ ao defender que a obrigação de prestar contas é indeclinável, múnus público inescusável dos gestores de bens, valores ou recursos públicos, exigível, em virtude da origem pública do bem administrado, seja qual for a natureza do órgão ou da pessoa que os administra.

199 OLIVEIRA, Regis Fernandes de. Curso de direito financeiro. 7. ed. São Paulo: Revista dos Tribunais, 2015. p. 719.

${ }^{200}$ CONTI, José Mauricio. Direito financeiro na Constituição de 1988. São Paulo: Editora Oliveira Mendes, 1998. p. 11.

201 A respeito da exigência de prestação de contas dos responsáveis por empresas públicas, sociedades de economia mista, fundaçóes, fundos contábeis, subsidiárias e holdings das empresas públicas e sociedades de economia mista, vejam-se os enunciados de número 6, 7, 8, 73, 75 e 80 da Súmula de jurisprudência do TCU, emitidos entre 1973 e 1976, cf. BRASIL. Tribunal de Contas da União. Súmulas n. 001 a 289. Brasília: Tribunal de Contas da União, 2016. Disponível em: http://portal.tcu.gov.br/main.jsp?lu mPageId $=8$ A 8182A15753C07D015 7679FA075237C \& previewItemId $=8$ A8182A25753C20F0157679 AA5617070\&lumItemId=8A8182A25753C20F0157679AA5677074. Acesso em: 30 mar. 2017. p. 211; $216 ; 218 ; 283-285$.

${ }^{202}$ MEIRELLES, Hely Lopes. A administração pública e seus controles. Revista de Direito Administrativo, Rio de Janeiro, n. 114, p. 23-33, out./dez. 1973. p. 30-31. 


\section{•. Contas dos governantes}

Veja-se que o manejo de dinheiros, bens e valores públicos, cujas diversas facetas foram abarcadas no transcrito parágrafo único do artigo 70 da CRFB/1988, segundo Emerson Cesar da Silva Gomes, é "[...] atividade estatal mais ampla que a atividade financeira [...]" ${ }^{203}$, compreendendo, além do manejo de recursos financeiros, atos de gestão patrimonial, atos de gestão de recursos humanos e atos referentes a renúncias de receita - como exemplifica -, ainda que não envolvam diretamente recursos financeiros. Nesse aspecto, os constituintes atenderam às lições de Geraldo Ataliba, segundo quem as exigências do princípio republicano forçam o intérprete a ampliar os conceitos de bens, responsabilidade, administração e prestação de contas, de modo que abranjam "[...] todos os agentes e todos os bens que de qualquer modo sejam relacionados com o interesse público, independentemente do regime a que a lei os submeta"204.

Logo, o sujeito passivo de accountability pública no âmbito contábil, financeiro, orçamentário, operacional e patrimonial da União, dos estados, do Distrito Federal e dos municípios é todo aquele - inclusive os chefes de Poder Executivo - que, de qualquer modo, manejar recursos públicos - entendendo-se tanto o verbo manejar como a expressão recursos públicos de forma ampla -, tanto da administração direta quanto da indireta, abarcando os poderes Executivo, Legislativo e Judiciário, os ministérios públicos, as defensorias públicas e os tribunais de contas.

Se há, por um lado, necessidade de ampla prestação de contas, por outro deve haver fiscalização e controle 205 . É que, como observa Luiz Fernando Rodrigues Pinto Junior, “[...] o dever de prestar contas e a necessidade de fiscalização e controle dos atos da administração pública estão intimamente ligados”206. Assim, como defende José Mauricio Conti ${ }^{207}$, o controle da administração deve ser tão amplo quanto possível, pois, como assevera João Ricardo Catarino, "Não há [nem pode haver] receita nem gasto público sem controlo" 208 .

203 GOMES, Emerson Cesar da Silva. Responsabilidade financeira: uma teoria sobre a responsabilidade no âmbito dos tribunais de contas. 2009. 379 f. Dissertação (Mestrado em Direito) - Departamento de Direito Econômico, Financeiro e Tributário, Faculdade de Direito, Universidade de São Paulo, São Paulo, 2009. f. 44.

204 ATALIBA, Geraldo. Extensão do conceito de bem público para efeito de controle financeiro interno e externo. Revista de Informação Legislativa, Brasília, v. 22, n. 86, p. 283-300, abr./jun. 1985. p. 300.

205 A respeito das origens do controle da administração pública, cf. SCLIAR, Wremyr. Tribunal de contas: do controle na antiguidade à instituição independente do estado democrático de direito. 2014. 294 f. Tese (Doutorado em Direito) - Faculdade de Direito, Pontifícia Universidade Católica do Rio Grande do Sul, Porto Alegre, 2014.

206 PINTO JUNIOR, Luiz Fernando Rodrigues. Fiscalização patrimonial da administração pública. 2013. 303 f. Dissertação (Mestrado em Direito) - Departamento de Direito Econômico, Financeiro e Tributário, Faculdade de Direito, Universidade de São Paulo, São Paulo, 2013. f. 94.

207 CONTI, José Mauricio. Direito financeiro na Constituição de 1988. São Paulo: Oliveira Mendes, 1998. p. 2.

${ }^{208}$ CATARINO, João Ricardo. Finanças públicas e direito financeiro. 4. ed. Coimbra: Almedina, 2018. p. 398. 
Hely Lopes Meirelles ensinava que "Controle, em tema de administração pública, é a faculdade de vigilância, orientação e correção que um Poder, órgão ou autoridade exerce sobre a conduta funcional de outro" ${ }^{209}$. José dos Santos Carvalho Filho, por seu turno, em conceito que aborda aspecto complementar àquele, denomina de "[...] controle da Administração Pública o conjunto de mecanismos jurídicos e administrativos por meio dos quais se exerce o poder de fiscalização e de revisão da atividade administrativa em qualquer das esferas de Poder"210.

O controle, segundo Massimo Severo Giannini ${ }^{211}$, invariavelmente, envolve três elementos, quais sejam: (i) uma verificação, que é um exame sobre uma conduta do agente controlado, tendo como critério uma norma; (ii) um juízo, decorrente da verificação, que pode ser positivo, negativo ou parcial; e (iii) uma providência, adotada pelo controlador ou proposta para adoção por outra autoridade. Trata-se, como resume Thiago Marrara ${ }^{212}$, de conhecer para corrigir. Para Odete Medauar, porém, entre os elementos expostos por Massimo Severo Giannini, a providência parece ser supérflua, pois assevera que "[...] o controle significa a verificação da conformidade da atuação da Administração Pública a certos parâmetros, independentemente de ser adotada, pelo controlador, medida que afete, do ponto de vista jurídico, a decisão ou o agente" 213 .

Essa concepção de controle como verificação ou exame, segundo José Mauricio Conti e André Castro Carvalho, é característica dos países de origem latina. Eles destacam, contudo, que a influência dos países anglo-saxões - e sua proatividade - contribui para a transformação dessa visão, de forma que, "[...] mesmo nos países latinos, como o Brasil, a verificação dos atos tem evoluído para um controle com base na prevenção, orientação e correção" ${ }^{214}$. Tal evolução é condizente com o que se observa na esfera da Organização para a Cooperação e Desenvolvimento Econômico (OCDE), onde, de acordo com Michael Ruffner e Joaquin Sevilla, "O controle é amplamente definido como um processo projetado para fornecer razoável segurança quanto à efi-

${ }^{209}$ MEIRELLES, Hely Lopes. Direito administrativo brasileiro. 43. ed. São Paulo: Malheiros, 2018. p. 830.

210 CARVALHO FILHO, José dos Santos. Manual de direito administrativo. 33. ed. São Paulo: Atlas, 2019. p. 1005.

211 GIANNINI, Massimo Severo. Istituzioni di diritto amministrativo. Milão: Giuffrè, 1981. p. 48-49.

${ }^{212}$ MARRARA, Thiago. Controle interno da administração pública: suas facetas e seus inimigos. In: MARRARA, Thiago; AGUDO GONZÁLEZ, Jorge. Controles da administração e judicialização de políticas públicas. São Paulo: Almedina, 2016. p. 49.

213 MEDAUAR, Odete. Controle da administração pública. 3. ed. São Paulo: Revista dos Tribunais, 2014. p. 32.

214 CONTI, José Mauricio; CARVALHO, André Castro. O controle interno na administração pública brasileira: qualidade do gasto público e responsabilidade fiscal. Direito Público, n. 37, p. 201-220, jan./ fev. 2011. p. 203. 


\section{-• Contas dos governantes}

cácia e eficiência das operações, confiabilidade de relatórios e conformidade com as leis e regulamentos aplicáveis" ${ }^{215}$.

Segundo Michel Bouvier, Marie-Christine Esclassan e Jean-Pierre Lassale ${ }^{216}$, se inicialmente, no âmbito financeiro e orçamentário, a preocupação focava-se exclusivamente no controle da regularidade, contemporaneamente, ela se volta também para a necessidade de avaliação da qualidade da gestão financeira e orçamentária da Administração Pública. Tal preocupação com o controle dos resultados da atuação estatal, como destaca Rodrigo Pagani de Souza ${ }^{217}$, torna-se cada vez mais acentuada no direito brasileiro.

Tendo em conta os conceitos apresentados, conclui-se que o controle, realizado no âmbito da accountability financeira e orçamentária da Administração Pública brasileira, deve ser projetado tanto para assegurar a conformidade estrita com as normas e a confiabilidade das informaçôes disponibilizadas ao público como para contribuir com a obtenção de resultados satisfatórios na prestação de serviços públicos.

Com o objetivo de atender a tal expectativa, como ensina Celso Antônio Bandeira de $\mathrm{Mello}^{218}$, a Administração Pública se submete a múltiplos controles ${ }^{219}$. Deve-se ter em mente que essa multiplicidade e amplitude dos controles é decorrente, especialmente, da influência do princípio republicano nas democracias representativas contemporâneas, como meio para controlar o poder e desencorajar a corrupção. Para atender a essa ampla expectativa, o caput do artigo 70 da CRFB/1988 estabelece que:

Art. 70. A fiscalização contábil, financeira, orçamentária, operacional e patrimonial da União e das entidades da administração direta e indireta, quanto à legalidade, legitimidade, economicidade, aplicação das subvenções e renúncia de receitas, será exercida pelo Congresso Nacional, mediante controle externo, e pelo sistema de controle interno de cada Poder ${ }^{220}$.

215 RUFFNER, Michael; SEVILLA, Joaquin. Public sector modernisation: modernising accountability and control. OECD Journal on Budgeting, Paris, v. 4, n. 2, p. 123-141, 2004. p. 126 (tradução nossa).

216 BOUVIER, Michel; ESCLASSAN, Marie-Christine; LASSALE, Jean-Pierre. Finances publiques. 17. ed. Paris: LDGJ, 2018. p. 509.

217 SOUZA, Rodrigo Pagani de. Em busca de uma administração pública de resultados. In: PEREZ, Marcos Augusto. SOUZA, Rodrigo Pagani de (Coord.). Controle da administraçáo pública. Belo Horizonte: Fórum, 2017. p. 52.

218 MELLO, Celso Antônio Bandeira de. Curso de direito administrativo. 33. ed. São Paulo: Malheiros, 2016. p. 965.

219 Para uma visão crítica a respeito da ampliação, com sobreposições, do controle sobre a Administração Pública, cf. MARQUES NETO, Floriano de Azevedo. Os grandes desafios do controle da administração pública. Fórum de Contratação e Gestão Pública - FCGP, Belo Horizonte, a. 9, n. 100, abr. 2010. Disponível em: https://www.forumconhecimento.com.br/periodico/138/21419/52192. Acesso em: 21 out. 2019; e MARQUES NETO, Floriano de Azevedo; PALMA, Juliana Bonacorsi de. Os sete impasses do controle da administração pública no Brasil. In: PEREZ, Marcos Augusto. SOUZA, Rodrigo Pagani de (Coord.). Controle da administração pública. Belo Horizonte: Fórum, 2017. p. 21-38.

220 BRASIL. Constituição (1988). Constituição da República Federativa do Brasil. Disponível em: http:// www.planalto.gov.br/ccivil_03/Constituicao/Constituicao.htm. Acesso em: 2 dez. 2019. 
O rico dispositivo constitucional determina, em relação à accountability financeira e orçamentária da Administração Pública brasileira, os tipos de fiscalização que podem ser exercidos, os aspectos a serem controlados, o modelo de controle e quais os agentes - sujeitos ativos - de accountability. Esses pontos são objetos das seçôes a seguir.

\subsection{FISCALIZAÇÃO CONTÁBIL, FINANCEIRA, ORÇAMENTÁRIA, OPERACIONAL E PATRIMONIAL}

No artigo 70, caput, da CRFB/1988, transcrito acima, foram previstos, como tipos ou modalidades de fiscalização, (i) a contábil, (ii) a financeira, (iii) a orçamentária, (iv) a operacional e (v) a patrimonial.

Ao tratar especificamente da fiscalização contábil, Luiz Fernando Rodrigues Pinto Junior explica que "O objetivo da contabilidade é captar, registrar, acumular, resumir e interpretar fenômenos que afetam as situações orçamentárias, financeiras e patrimoniais das entidades do Direito Público Interno", de modo que as "Demonstraçôes contábeis são preparadas e apresentadas para auxiliar os usuários das informações na avaliação das posiçóes financeira e patrimonial assim como as perspectivas futuras"221. José Mauricio Conti ensina que a "A fiscalização contábil é realizada por meio da verificação e análise das peças e registros contábeis da Administração Pública e seus órgãos, com a finalidade de apurar a correção dos atos desta natureza"222.

Por correção, quer-se dizer que as informações contábeis devem ser tempestivas, integrais e confiáveis. Devem ser tempestivas para que, como leciona Luiz Fernando Rodrigues Pinto Junior, “[...] o tomador de decisões possa extrair o máximo de utilidade da informação para os propósitos a que se destina" ${ }^{223}$. Devem ser integrais, de forma que compreendam "[...] todos os elementos relevantes e significativos sobre o que se pretende revelar ou divulgar $[. .].]^{\prime 224}$. Por fim, como ensina ${ }^{225}$, devem observar os postulados, princípios e convenções fundamentais de contabilidade e os preceitos da

221 PINTO JUNIOR, Luiz Fernando Rodrigues. Fiscalização patrimonial da administração pública. 2013. 303 f. Dissertação (Mestrado em Direito) - Departamento de Direito Econômico, Financeiro e Tributário, Faculdade de Direito, Universidade de São Paulo, São Paulo, 2013. f. 145-146; 149.

222 CONTI, José Mauricio. Direito financeiro na Constituição de 1988. São Paulo: Oliveira Mendes, 1998. p. 3.

${ }^{223}$ PINTO JUNIOR, Luiz Fernando Rodrigues. Fiscalização patrimonial da administração pública. 2013. 303 f. Dissertação (Mestrado em Direito) - Departamento de Direito Econômico, Financeiro e Tributário, Faculdade de Direito, Universidade de São Paulo, São Paulo, 2013. f. 155-156.

${ }^{224}$ PINTO JUNIOR, Luiz Fernando Rodrigues. Fiscalização patrimonial da administração pública. 2013. 303 f. Dissertação (Mestrado em Direito) - Departamento de Direito Econômico, Financeiro e Tributário, Faculdade de Direito, Universidade de São Paulo, São Paulo, 2013. f. 156.

225 PINTO JUNIOR, Luiz Fernando Rodrigues. Fiscalização patrimonial da administração pública. 2013. 303 f. Dissertação (Mestrado em Direito) - Departamento de Direito Econômico, Financeiro e Tributário, Faculdade de Direito, Universidade de São Paulo, São Paulo, 2013. f. 156. 


\section{•. Contas dos governantes}

doutrina contábil, de modo que sejam confiáveis e possam ser utilizadas pelos usuários como fundamento para a tomada de decisões.

Logo, a fiscalização contábil deve apurar se as informações contábeis apresentadas pelos poderes e órgãos da Administração Pública são tempestivas, integrais e confiáveis. Nesse sentido, Luiz Fernando Rodrigues Pinto Junior assevera que

[...] "Fiscalização Contábil" é aquela que se efetua por meio do controle realizado sobre os registros contábeis determinados legalmente, objetivando examinar e verificar a regularidade e a correção técnica da escrituração, a legitimidade dos atos e fatos que deram origem aos lançamentos e a formalização da documentação comprobatória, medindo e avaliando a segurança e a eficiência do sistema de controle interno, próprias do sistema contábil ${ }^{226}$.

Edson Simões ${ }^{227}$ destaca que a fiscalização contábil serve de base para os demais tipos de fiscalização. Entre os demais tipos, tem-se a fiscalização financeira, que, nos termos utilizados por Regis Fernandes de Oliveira, "[...] diz respeito ao ingresso e à saída de dinheiro" 228 , portanto, à arrecadação de receitas e à realização de despesas, como explica Marcus Abraham ${ }^{229}$.

Nesse sentido, a respeito da fiscalização financeira, Luiz Fernando Rodrigues Pinto Junior afirma que "É a fiscalização que indica diretamente a movimentação de recursos financeiros no caixa do Poder Público, isto é, a entrada e saída de dinheiro público em todos os aspectos, seja patrimonial, seja operacional”230. Segundo ele, seu objetivo é "[...] verificar se as contas públicas representam a efetiva situação financeira da administração, envolvendo controle sobre a arrecadação da receita e a realização da despesa, tendo em conta a legalidade e a regularidade das suas operações" ${ }^{\prime 31}$.

Ricardo Lobo Torres ${ }^{232}$ diferenciava a fiscalização financeira da orçamentária em razão de seu objeto, sendo esta a exercida sobre o orçamento e aquela sobre a realização

226 PINTO JUNIOR, Luiz Fernando Rodrigues. Fiscalização patrimonial da administração pública. 2013. 303 f. Dissertação (Mestrado em Direito) - Departamento de Direito Econômico, Financeiro e Tributário, Faculdade de Direito, Universidade de São Paulo, São Paulo, 2013. f. 156.

227 SIMŌES, Edson. Tribunais de contas. In: MARTINS, Ives Gandra; MENDES, Gilmar; NASCIMENTO, Carlos Valder do. Tratado de direito financeiro. v. 2. São Paulo: Saraiva, 2013. p. 236-237.

228 OLIVEIRA, Regis Fernandes de. Curso de direito financeiro. 7. ed. São Paulo: Revista dos Tribunais, 2015. p. 719.

229 ABRAHAM, Marcus. Curso de direito financeiro brasileiro. 3. ed. Rio de Janeiro: Forense, 2015. p. 312.

230 PINTO JUNIOR, Luiz Fernando Rodrigues. Fiscalização patrimonial da administração pública. 2013. 303 f. Dissertação (Mestrado em Direito) - Departamento de Direito Econômico, Financeiro e Tributário, Faculdade de Direito, Universidade de São Paulo, São Paulo, 2013. f. 157.

231 PINTO JUNIOR, Luiz Fernando Rodrigues. Fiscalização patrimonial da administração pública. 2013. 303 f. Dissertação (Mestrado em Direito) - Departamento de Direito Econômico, Financeiro e Tributário, Faculdade de Direito, Universidade de São Paulo, São Paulo, 2013. f. 156.

232 TORRES, Ricardo Lobo. Curso de direito financeiro e tributário. 20. ed. Rio de Janeiro: Renovar, 2018. p. 198. 
de receitas e despesas. Regis Fernandes de Oliveira afirma que a fiscalização "[...] orçamentária incide sobre a correta aplicação da lei orçamentária, isto é, as verbas apenas podem ter a destinação prevista no texto da lei especial aprovada"233. Outrossim, segundo Luiz Fernando Rodrigues Pinto Junior,

[...] a fiscalização orçamentária visa proceder a um acompanhamento de verificação de execução orçamentária propriamente dita, com exame sobre a execução dos programas, projetos e atividades determinados pela lei orçamentária, com observância de fiel cumprimento das normas, procedimentos e dispositivos legais que envolvem todo o ciclo orçamentário, desde a elaboração do Plano de Governo, a Lei de Diretrizes Orçamentárias e o Orçamento Anual, incluindo métodos de controle dos créditos orçamentários ou adicionais até o registro dos fatos pela contabilidade.

Possibilita a verificação dos planos de governo no sentido de impedir o desvio de finalidade dos recursos financeiros, evitando que recurso reservado para determinado projeto ou atividade seja aplicado em outra despesa sem autorização da lei de orçamento ${ }^{234}$.

A fiscalização operacional, por sua vez, incide sobre os processos e projetos, operacionais e gerenciais, da Administração Pública, tanto os referentes à obtenção de recursos quanto os destinados à execução de políticas públicas e prestação de serviços públicos.

Regis Fernandes de Oliveira destaca que "A operacionalidade significa que deve haver rigoroso controle sobre as formas de procedimento da despesa, atendendo-se ao atingimento dos objetivos traçados" ${ }^{235}$. Desse modo, o tipo de fiscalização operacional, combinado com a fiscalização quanto ao aspecto da economicidade e com o princípio da eficiência da administração pública - previsto no artigo $37 \mathrm{da}$ CRFB/1988 - é o fundamento da realização das auditorias de desempenho - também denominadas de operacionais -, das quais se trata adiante, na subseção 2.6.7.2 (p. 148) deste trabalho.

Por fim, a fiscalização patrimonial, como ensina José Mauricio Conti ${ }^{236}$, envolve os bens integrantes do patrimônio público. Para Luiz Fernando Rodrigues Pinto

233 OLIVEIRA, Regis Fernandes de. Curso de direito financeiro. 7. ed. São Paulo: Revista dos Tribunais, 2015. p. 719.

234 PINTO JUNIOR, Luiz Fernando Rodrigues. Fiscalização patrimonial da administração pública. 2013. 303 f. Dissertação (Mestrado em Direito) - Departamento de Direito Econômico, Financeiro e Tributário, Faculdade de Direito, Universidade de São Paulo, São Paulo, 2013. f. 157-158.

235 OLIVEIRA, Regis Fernandes de. Curso de direito financeiro. 7. ed. São Paulo: Revista dos Tribunais, 2015. p. 719.

236 CONTI, José Mauricio. Direito financeiro na Constituição de 1988. São Paulo: Oliveira Mendes, 1998. p. 3-4. 


\section{•. Contas dos governantes}

Junior, "[...] é aquela que diz respeito a alterações ou modificações dos bens patrimoniais cuja titularidade pertence ao Estado ou assemelhado [...], com escopo principal de proteção e conservação do patrimônio físico" ${ }^{237}$. Regis Fernandes de Oliveira também destaca as alterações patrimoniais como objeto da fiscalização patrimonial da Administração Pública, que deve ser exercida “[...] em benefício da preservação dos bens que integram o patrimônio público"238.

Segundo José Mauricio Conti, "Integra o patrimônio público [...] todo e qualquer bem, material e imaterial, que tenha valor econômico e pertença, direta ou indiretamente, ao Poder Público" ${ }^{239}$. Luiz Fernando Rodrigues Pinto Junior ${ }^{240}$ classifica o patrimônio público em próprio e impróprio. Em sua classificação, aquele engloba os bens imobiliários e mobiliários e está inteiramente sujeito à fiscalização patrimonial - e, também, contábil, financeira, orçamentária e operacional - exercida pelos agentes de accountability.

O patrimônio público impróprio, por outro lado, abrange o conjunto de bens jurídicos sociais - como os direitos fundamentais previstos na CRFB/1988 - e o patrimônio público diferido - formado por “[...] bens jurídicos sob tutela de entidade de que o Estado não participe e que exerça atividade própria ou imprópria do Poder Público, mas de interesse da sociedade, e sem integrar o Estado [...]"241. De acordo com Luiz Fernando Rodrigues Pinto Junior ${ }^{242}$, o patrimônio público impróprio, inclusive o meio ambiente, não seria objeto da fiscalização patrimonial exercida pelos agentes de accountability. Para o autor, seu controle deve ocorrer " [...] por meio de procedimentos administrativos [...], de ações civis públicas, ações populares, mandados de segurança etc. [...] e também pelas agências reguladoras" 243 .

237 PINTO JUNIOR, Luiz Fernando Rodrigues. Fiscalização patrimonial da administração pública. 2013. 303 f. Dissertação (Mestrado em Direito) - Departamento de Direito Econômico, Financeiro e Tributário, Faculdade de Direito, Universidade de São Paulo, São Paulo, 2013. f. 163.

238 OLIVEIRA, Regis Fernandes de. Curso de direito financeiro. 7. ed. São Paulo: Revista dos Tribunais, 2015. p. 719.

239 CONTI, José Mauricio. Direito financeiro na Constituição de 1988. São Paulo: Oliveira Mendes, 1998. p. 3-4.

240 PINTO JUNIOR, Luiz Fernando Rodrigues. Fiscalização patrimonial da administração pública. 2013. 303 f. Dissertação (Mestrado em Direito) - Departamento de Direito Econômico, Financeiro e Tributário, Faculdade de Direito, Universidade de São Paulo, São Paulo, 2013. f. 266-267.

241 PINTO JUNIOR, Luiz Fernando Rodrigues. Fiscalização patrimonial da administração pública. 2013. 303 f. Dissertação (Mestrado em Direito) - Departamento de Direito Econômico, Financeiro e Tributário, Faculdade de Direito, Universidade de São Paulo, São Paulo, 2013. f. 267.

242 PINTO JUNIOR, Luiz Fernando Rodrigues. Fiscalização patrimonial da administração pública. 2013. 303 f. Dissertação (Mestrado em Direito) - Departamento de Direito Econômico, Financeiro e Tributário, Faculdade de Direito, Universidade de São Paulo, São Paulo, 2013. f. 267.

243 PINTO JUNIOR, Luiz Fernando Rodrigues. Fiscalização patrimonial da administração pública. 2013. 303 f. Dissertação (Mestrado em Direito) - Departamento de Direito Econômico, Financeiro e Tributário, Faculdade de Direito, Universidade de São Paulo, São Paulo, 2013. f. 267. 
Nesse sentido, Emerson Cesar da Silva Gomes ${ }^{244}$ entende que a atuação dos tribunais de contas deve restringir-se aos bens e valores de natureza patrimonial. Tanto que, para ele, “[...] a responsabilidade financeira reintegratória não é o instrumento jurídico adequado para o ressarcimento dos danos de natureza moral, ambiental, histórica ou cultural" 245 , cabendo, porém, outras modalidades de responsabilidade.

Contudo, os tribunais de contas - em consonância com as diretrizes consensadas no âmbito da International Organization of Supreme Audit Institutions (INTOSAI) ${ }^{246}$, instituição que congrega as instituiçôes superiores responsáveis pelo controle externo em cento e noventa e três países e na União Europeia, inclusive o TCU pelo Brasil -, reunidos no I Simpósio Internacional sobre Gestão Ambiental e Controle de Contas Públicas, em 2010, firmaram a Carta da Amazônia, comprometendo-se a incluir as questôes ambientais em suas fiscalizações, do seguinte modo:

2. O controle das contas públicas das diversas esferas governamentais deve considerar a competência comum relacionada à proteção do meio ambiente, o que leva à necessária colaboração entre os Tribunais de Contas, nos vários níveis de organização do Estado brasileiro, com intercâmbio contínuo de conhecimento e atuação conjunta, quando indicada.

[...]

4. Para que os Tribunais de Contas cumpram seu papel constitucional em relação à proteção do meio ambiente é imperativo que incluam as questôes ambientais em todas as dimensões das auditorias de sua competência, capacitando continuamente os profissionais e proporcionando-lhes meios adequados para sua atuação ${ }^{247}$.

244 GOMES, Emerson Cesar da Silva. Responsabilidade financeira: uma teoria sobre a responsabilidade no âmbito dos tribunais de contas. 2009. 379 f. Dissertação (Mestrado em Direito) - Departamento de Direito Econômico, Financeiro e Tributário, Faculdade de Direito, Universidade de São Paulo, São Paulo, 2009. f. 44.

245 GOMES, Emerson Cesar da Silva. Responsabilidade financeira: uma teoria sobre a responsabilidade no âmbito dos tribunais de contas. 2009. 379 f. Dissertação (Mestrado em Direito) - Departamento de Direito Econômico, Financeiro e Tributário, Faculdade de Direito, Universidade de São Paulo, São Paulo, 2009. f. 44.

246 Cf. INTERNATIONAL ORGANIZATION OF SUPREME AUDIT INSTITUTIONS (INTOSAI). Working Group on Environmental Auditing. Susteinable development: the role of supreme audit institutions. Budapest: INTOSAI, 2004. Disponível em: https://www.environmental-auditing.org/media/2892/eng04pu_guidesusdevsairole.pdf. Acesso em: 21 out. 2019; INTERNATIONAL ORGANIZATION OF SUPREME AUDIT INSTITUTIONS (INTOSAI). Working Group on Environmental Auditing. Greening SAIs. Jacarta: INTOSAI, 2016. Disponível em: https:/www.environmental-auditing.org/media/5369/wgea-greening-sais_isbn-ok.pdf. Acesso em: 21 out. 2019; e CONGRESS OF INTOSAI, XXIII, 2019, Moscow. Moscow declaration. Moscow: 2019. Disponível em: https://www. intosai.org/fileadmin/downloads/news_centre/events/congress/accords_declarations/EN_ 23_Moscow_Decl_300919.pdf. Acesso em: 21 out. 2019. p. 9.

247 SIMPÓSIO INTERNACIONAL SOBRE GESTÃO AMBIENTAL E CONTROLE DE CONTAS PÚBLICAS, I, 2010, Manaus. Carta da Amazônia. Manaus: 2010. Disponível em: http://cpsustentaveis.planejamento.gov.br/assets/conteudo/uploads/carta-da-amazoniaagendatribunais-de-contas.pdf. Acesso em: 4 abr. 2017. 


\section{•. Contas dos governantes}

Logo, o entendimento prevalecente no âmbito das cortes de contas parece acompanhar Ricardo Lobo Torres ${ }^{248}$, segundo quem o meio ambiente não só está incluído no patrimônio público como deve ser objeto da fiscalização patrimonial ${ }^{249}$.

Vale destacar que, embora a CRFB/1988 tenha previsto cinco tipos de fiscalização, e nesta seção eles tenham sido tratados em sequência, na realidade, como observa Luiz Fernando Rodrigues Pinto Junior, “[...] há, em diversos momentos, mescla das distintas fiscalizações, ao mesmo tempo em que se interpenetram auxiliando-se mutuamente. Embora distintos os conceitos, atuam sobrepostas [...]"250.

Desse modo, os tipos ou modalidades de fiscalização contábil, financeira, orçamentária, operacional e patrimonial tratam de um leque de opções conferidas às agências de accountability financeira e orçamentária da Administração Pública, que diversificam suas ações, selecionando, em cada caso, os tipos mais adequados para manter os administradores públicos responsáveis - accountable.

Tratando-se, nesta seção, dos tipos de fiscalização previstos no caput do artigo 70 da CRFB/1988, as seções seguintes deste trabalho se dedicam aos aspectos a serem controlados, ao sistema de controle e sujeitos ativos de accountability, em sua vertente financeira e orçamentária.

\subsection{CONTROLE QUANTO À LEGALIDADE, LEGITIMIDADE E ECONOMICIDADE}

Além dos tipos ou modalidades de fiscalização, dos quais trata a seção anterior, o caput do artigo 70 da CRFB/1988 prevê que a fiscalização financeira e orçamentária da Administração Pública se dará quanto aos aspectos da (i) legalidade, (ii) legitimidade, (iii) economicidade, (iv) aplicação das subvenções e (v) renúncia de receitas.

248 TORRES, Ricardo Lobo. Curso de direito financeiro e tributário. 20. ed. Rio de Janeiro: Renovar, 2018. p. 198-199.

249 A respeito do controle de sustentabilidade ecológica e ambiental pelos tribunais de contas, incluindo a destinação de resíduos sólidos, o saneamento ambiental, o controle de qualidade das águas, os índices de poluição, os impactos ambientais e a priorização à utilização de energias renováveis e à aquisição de produtos e serviços sustentáveis, cf. CUNDA, Daniela Zago Gonçalves da. Controle de sustentabilidade pelos tribunais de contas. 2016. $321 \mathrm{f}$. Tese (Doutorado em Direito) - Faculdade de Direito, Pontifícia Universidade Católica do Rio Grande do Sul, Porto Alegre, 2016; CUNDA, Daniela Zago Gonçalves da. Controle de sustentabilidade pelos Tribunais de Contas: proposta de marco legal a ser utilizado no controle externo concretizador da sustentabilidade ambiental. Interesse Público - IP, Belo Horizonte, a. 18, n. 96, p. 187-218, mar./abr. 2016; COSTA, Paulo Nogueira da. O tribunal de contas e a boa governança. 2. ed. Lisboa: Petrony Editora, 2017. p. 368-381; e ALVES, Benedito Antonio. A governança da sustentabilidade ambiental a cargo dos tribunais de contas no século XXI. In: LIMA, Edilberto Carlos Pontes (Coord.). Tribunal de Contas do século XXI. Belo Horizonte: Fórum, 2020. p. 19-47. (Coleção Fórum IRB, v. 3).

250 PINTO JUNIOR, Luiz Fernando Rodrigues. Fiscalização patrimonial da administração pública. 2013. 303 f. Dissertação (Mestrado em Direito) - Departamento de Direito Econômico, Financeiro e Tributário, Faculdade de Direito, Universidade de São Paulo, São Paulo, 2013. f. 163. 
Vitor Rolf Laubé251, já nos primeiros anos após a promulgação da Constituição, percebeu o alargamento das possibilidades e do alcance da accountability financeira e orçamentária no Brasil.

Regis Fernandes de Oliveira ensina que, no âmbito orçamentário e financeiro, fiscalizar a legalidade significa verificar a “[...] obediência aos requisitos necessários para que pudesse ter ocorrido a despesa, bem como da previsão para que ela pudesse realizar-se" 252 . Desse modo, de acordo com Ricardo Lobo Torres, tal controle deve se concentrar “[...] sobre a legalidade dos atos e operaçôes necessárias à execução do orçamento. Mas não se esgota na legalidade estrita, na mera adequação do ato à lei formal [...]”, abarcando, ainda, o "[...] exame da adequação da gestão financeira ao orçamento e às leis materiais dos tributos e da despesa pública [...]. Abrange, também, o exame formal das contas, seus aspectos de certeza, exatidão e correção de números e cálculos”253.

Pelo controle de legalidade, no entender de Lucas Rocha Furtado, se "[...] verifica a adequação ou conformidade do ato ao ordenamento jurídico" 254 , que compreende não somente a lei. Portanto, a adequação pode se dar perante atos legais, infralegais por exemplo, decretos e portarias - e, até mesmo, diante da CRFB/1988. Aliás, a fiscalização financeira e orçamentária quanto ao aspecto da legalidade é o fundamento para aqueles que defendem que os agentes de accountability financeira e orçamentária - neste caso, especificamente, os tribunais de contas -, no exercício de sua atividade, podem negar, com fundamento em suposta inconstitucionalidade, aplicação a leis e atos administrativos ${ }^{255}$.

251 LAUBÉ, Vitor Rolf. Considerações acerca da conformação constitucional do tribunal de contas. Revista de Informação Legislativa, Brasília, v. 29, n. 113, p. 307-326, jan./mar. 1992. p. 315.

252 OLIVEIRA, Regis Fernandes de. Curso de direito financeiro. 7. ed. São Paulo: Revista dos Tribunais, 2015. p. 719.

253 TORRES, Ricardo Lobo. A legitimidade democrática e o tribunal de contas. Revista de Direito Administrativo, Rio de Janeiro, n. 194, p. 31-45, out./dez. 1993. p. 35-36.

${ }^{254}$ FURTADO, Lucas Rocha. Curso de direito administrativo. 5. ed. Belo Horizonte: Fórum, 2016. p. 916.

255 A respeito da possibilidade de os tribunais de contas negarem aplicação a norma que entenderem inconstitucional, cf. BRASIL. Supremo Tribunal Federal. Recurso em mandado de segurança n. 8.372 Ceará. Relator: Ministro Pedro Chaves. Tribunal Pleno, Brasília, 11 de dezembro de 1961. Diário da Justiça, Brasília, 25 abr. 1962. Disponível em: http://redir.stf.jus.br/paginadorpub/paginador.jsp?docTP=AC\&docID=108082. Acesso em: 4 abr. 2017; BRASIL. Supremo Tribunal Federal. Enunciado n. 347. In: Súmulas do STF. Atual. em 13 de fevereiro de 2017. Brasília: Supremo Tribunal Federal, 2017. Disponível em: http://www. stf.jus.br/arquivo/cms/jurisprudenciaSumula/anexo/Enunciados_Sumulas_STF_1_a_736_Completo. pdf. Acesso em: 4 abr. 2017. p. 226; TORRES, Ricardo Lobo. A legitimidade democrática e o tribunal de contas. Revista de Direito Administrativo, Rio de Janeiro, n. 194, p. 31-45, out./dez. 1993. p. 35-36; MENDES, Gilmar Ferreira. O Poder Executivo e o Poder Legislativo no controle de constitucionalidade. Revista de Informação Legislativa, Brasília, a. 34, n. 134, p. 11-39, abr./jun. 1997; CONTI, José Mauricio. Direito financeiro na Constituição de 1988. São Paulo: Oliveira Mendes, 1998. p. 3-4; BÚRGIO, Vandré Augusto. Controle de constitucionalidade dos atos normativos pelos tribunais de contas. Revista de direito administrativo, Rio de Janeiro, Fundação Getúlio Vargas, v. 228, p. 67-75, abr./jun. 2002. p. 73 74; FIGUEIREDO, Lúcia Valle. Competência dos tribunais administrativos para controle da constitucionalidade. Interesse Público - IP, Belo Horizonte, a. 6, n. 24, mar./abr. 2004. Disponível em: https://www. 
Marcus Abraham destaca que, enquanto o controle da legalidade confirma "[...] o atendimento formal das condições previstas na legislação financeira [...]", a fiscalização financeira e orçamentária quanto ao aspecto da legitimidade “[...] diz respeito à consideração das condições materiais e valorativas decorrentes das necessidades públicas que envolvem os atos administrativo-financeiros (demonstração da motivação dos atos e dos fins que se busca atingir)" 256 .

Nesse sentido, de acordo com Bruno Mitsuo Nagata ${ }^{257}$, no âmbito da accountability financeira e orçamentária da Administração Pública, a noção de legitimidade se confunde com a ideia de justiça material. Semelhantemente, para Régis Fernandes de Oliveira $^{258}$, a legitimidade vai além da legalidade, avalia se os recursos públicos são aplicados onde eles são necessários e se as necessidades públicas eleitas no planejamento financeiro e orçamentário foram atendidas.

forumconhecimento.com.br/periodico/172/21152/41129. Acesso em: 21 out. 2019; SCHMITT, Rosane Heineck. Tribunais de contas no Brasil e controle de constitucionalidade. 2006. $271 \mathrm{f}$. Tese (Doutorado em Direito) - Faculdade de Direito, Universidade Federal do Rio Grande do Sul, Porto Alegre, 2006; FREITAS, Juarez. O controle de constitucionalidade pelo Estado-administração. A\&C - Revista de Direito Administrativo \& Constitucional, Belo Horizonte, a. 10, n. 40, p. 217-238, abr./jun. 2010; WILLEMAN, Marianna Montebello. Controle de constitucionalidade por órgãos não jurisdicionais: a interpretação constitucional fora das cortes de justiça. Revista da Procuradoria Geral do Estado do Espírito Santo, Vitória, v. 12, n. 12, p. 283-326, 2012. Disponível em: https://pge.es.gov.br/Media/pge/Publicações/Revista\%20PGE/PGE_12_editado.pdf. Acesso em: 21 out. 2019; PINTO JUNIOR, Luiz Fernando Rodrigues. Fiscalização patrimonial da administração pública. 2013. 303 f. Dissertação (Mestrado em Direito) Departamento de Direito Econômico, Financeiro e Tributário, Faculdade de Direito, Universidade de São Paulo, São Paulo, 2013. f. 184; ROSILHO, André Janjácomo. Controle da administração pública pelo Tribunal de Contas da Uniáo. 2016. 358 f. Tese (Doutorado em Direito) - Departamento de Direito do Estado, Faculdade de Direito, Universidade de São Paulo, São Paulo, 2016. f. 136-142; FALCÃO, Valdirene Ribeiro de Souza. O Tribunal de Contas e o controle de constitucionalidade: uma releitura da Súmula 347 do Supremo Tribunal Federal. In: PEREZ, Marcos Augusto; SOUZA, Rodrigo Pagani de. Controle da administração pública. Belo Horizonte: Fórum, 2017. p. 197-213; MORAES, Alexandre de. Direito constitucional. 35. ed. São Paulo: Atlas, 2019. p. 479-480; BRASIL. Supremo Tribunal Federal. Medida cautelar no mandado de segurança n. 35.410 Distrito Federal. Relator: Ministro Alexandre de Moraes. Decisão monocrática, Brasília, 15 de dezembro de 2017. Diário da Justiça Eletrônico, Brasília, n. 18, 1 fev. 2018. Disponível em: http://stf.jus.br/portal/jurisprudencia/listarJurisprudenciaDetalhe.asp?s1=00008320 $6 \&$ base $=$ baseMonocraticas. Acesso em: 21 out. 2019; BRASIL. Supremo Tribunal Federal. Medida cautelar no mandado de segurança n. 34.987 Distrito Federal. Relator: Ministro Edson Fachin. Decisão monocrática, Brasília, 18 de dezembro de 2017. Diário da Justiça Eletrônico, Brasília, n. 18, 1 fev. 2018. Disponível em: http://stf.jus.br/portal/jurisprudencia/listarJurisprudenciaDetalhe.asp?s1=000115087\&base=bas eMonocraticas. Acesso em: 21 out. 2019; MADUREIRA, Cláudio Penedo. Legalidade é juridicidade: notas sobre a (i)legitimidade da aplicação de leis inconstitucionais pela Administração Pública. A\&C - Revista de Direito Administrativo \& Constitucional, Belo Horizonte, a. 19, v. 75, p. 217-240, jan./mar. 2019. DOI: 10.21056/aec.v20i75.1098; e WILLEMAN, Marianna Montebello. A accountability democrática e o desenho institucional dos tribunais de contas no Brasil. 2. ed. Belo Horizonte: Fórum, 2020. p. 293-302.

256 ABRAHAM, Marcus. Curso de direito financeiro brasileiro. 3. ed. Rio de Janeiro: Forense, 2015. p. 312.

257 NAGATA, Bruno Mitsuo. Fiscalização financeira quanto à legitimidade. 2012. 237 f. Dissertação (Mestrado em Direito) - Departamento de Direito Econômico, Financeiro e Tributário, Faculdade de Direito, Universidade de São Paulo, São Paulo, 2012. p. 225.

258 OLIVEIRA, Regis Fernandes de. Curso de direito financeiro. 7. ed. São Paulo: Revista dos Tribunais, 2015. p. 720. 
Para José Mauricio Conti, o próprio mérito do objeto fiscalizado está no escopo na fiscalização quanto ao aspecto da legitimidade. Segundo ele, "[...] determinado ato, ainda que realizado em consonância com as leis, pode não ser legítimo, por afrontar princípios jurídicos outros, como o da moralidade administrativa, tornando-se ilegítimo e passível de impugnação [...]"259. Nesse sentido, o controle da legitimidade é relacionado ao controle da moralidade - por Ricardo Lobo Torres ${ }^{260}$-, da impessoalidade e da boa administração - conforme Luiz Fernando Rodrigues Pinto Junior ${ }^{261}$. Outrossim, para Bruno Mitsuo Nagata, "A legitimidade liga-se, ainda, à moralidade, à legalidade e à economicidade"262.

Em geral, relaciona-se a fiscalização financeira e orçamentária quanto ao aspecto da economicidade à avaliação da relação custo-benefício e à eficiência das ações administrativas, no tocante tanto às despesas públicas como à arrecadação.

Assim, José Mauricio Conti ${ }^{263}$ ensina que, nesse aspecto de controle, se verifica se a Administração Pública empregou os recursos públicos de maneira eficiente, especialmente sob o prisma da relação custo-benefício. Marcus Abraham apresenta a economicidade como "[...] a verificação da concretização da máxima eficiência da atividade financeira, no sentido de obter o maior aproveitamento das verbas públicas com o menor ônus possível, tudo dentro de um custo-benefício razoável”264.

Trata-se de analisar se o "[...] o caminho perseguido foi o melhor e mais amplo para chegar à despesa e se ela fez-se com modicidade, dentro da equação custo benefício" 265 , como leciona Regis Fernandes de Oliveira. Caio Tácito, antes mesmo da previsão constitucional da fiscalização quanto à economicidade, destacava que o controle sobre a Administração Pública deve ter duplo enfoque, por um lado atento à legalidade, por outro atento à eficiência, “[...] que tem em mira o aperfeiçoamento das instituições administrativas, cuidando de sua melhor produtividade" ${ }^{266}$. Ricardo Lobo

259 CONTI, José Mauricio. Direito financeiro na Constituição de 1988. São Paulo: Oliveira Mendes, 1998. p. 5.

260 TORRES, Ricardo Lobo. A legitimidade democrática e o tribunal de contas. Revista de Direito Administrativo, Rio de Janeiro, n. 194, p. 31-45, out./dez. 1993. p. 39.

261 PINTO JUNIOR, Luiz Fernando Rodrigues. Fiscalização patrimonial da administração pública. 2013. 303 f. Dissertação (Mestrado em Direito) - Departamento de Direito Econômico, Financeiro e Tributário, Faculdade de Direito, Universidade de São Paulo, São Paulo, 2013. p. 187.

262 NAGATA, Bruno Mitsuo. Fiscalização financeira quanto à legitimidade. 2012. 237 f. Dissertação (Mestrado em Direito) - Departamento de Direito Econômico, Financeiro e Tributário, Faculdade de Direito, Universidade de São Paulo, São Paulo, 2012. p. 225.

263 CONTI, José Mauricio. Direito financeiro na Constituição de 1988. São Paulo: Oliveira Mendes, 1998. p. 5.

264 ABRAHAM, Marcus. Curso de direito financeiro brasileiro. 3. ed. Rio de Janeiro: Forense, 2015. p. 312.

265 OLIVEIRA, Regis Fernandes de. Curso de direito financeiro. 7. ed. São Paulo: Revista dos Tribunais, 2015. p. 720.

266 TÁCITO, Caio. O controle da administração e a nova constituição do Brasil. Revista de Direito Administrativo, Rio de Janeiro, v. 90, p. 23-29, 1967. p. 24. 


\section{•- Contas dos governantes}

Torres $^{267}$, admitindo que o controle de economicidade se inspira na relação custo-benefício, subordinava-o à ideia de justiça, que para ele é o correspondente jurídico de um termo eminentemente econômico. Como explica,

Controle da economicidade significa controle da eficiência na gestão financeira e na execução orçamentária, consubstanciada na minimização de custos e gastos públicos e na maximização da receita e da arrecadação. Transcende o mero controle da economia de gastos, entendida como aperto ou diminuição de despesa, pois abrange também a receita, na qual aparece como efetividade na realização das entradas orçamentárias. É sobretudo, a justa adequação e equilíbrio entre as duas vertentes das finanças públicas ${ }^{268}$.

Eduardo Lobo Botelho Gualazzi ${ }^{269}$ elenca o controle de economicidade como uma das expressóes do controle de mérito, ao lado do controle de oportunidade, do controle de gestão e do controle de eficiência. De fato, a fiscalização financeira e orçamentária da Administração Pública quanto ao aspecto da economicidade, e o controle de eficiência daí resultante, é a porta de entrada para o controle dos resultados da atuação estatal.

Nesse sentido, Ricardo Lobo Torres assevera que "As finanças públicas no Estado Social de Direito [...] exigem também o controle de gestão, a análise de resultados e a apreciação da justiça e do custo/benefício, a ver se o cidadão realmente obtém a contrapartida do seu sacrifício econômico" ${ }^{270}$. Essa fiscalização de resultados, segundo Eduardo Lobo Botelho Gualazzi, vai além do controle de mérito. Como explica:

[...] o de mérito conecta-se apenas aos primeiros momentos de execução da atividade administrativa (assim permanecendo a nível hipotético, quanto aos resultados finais), ao passo que o de resultados abrange a totalidade dos frutos finais e definitivo da execução administrativa, já caracterizada e encerrada. Em termos lógico-formais de extensão, pois, o controle de legitimidade apresenta extensão mínima, o de mérito extensão média e o de resultados extensão máxima ${ }^{271}$.

267 TORRES, Ricardo Lobo. A legitimidade democrática e o tribunal de contas. Revista de Direito Administrativo, Rio de Janeiro, n. 194, p. 31-45, out./dez. 1993. p. 36-37.

268 TORRES, Ricardo Lobo. A legitimidade democrática e o tribunal de contas. Revista de Direito Administrativo, Rio de Janeiro, n. 194, p. 31-45, out./dez. 1993. p. 36-37.

269 GUALAZZI, Eduardo Lobo Botelho. Regime jurídico dos tribunais de contas. São Paulo: Revista dos Tribunais, 1992. p. 51.

270 TORRES, Ricardo Lobo. A legitimidade democrática e o tribunal de contas. Revista de Direito Administrativo, Rio de Janeiro, n. 194, p. 31-45, out./dez. 1993. p. 39.

271 GUALAZZI, Eduardo Lobo Botelho. Regime jurídico dos tribunais de contas. São Paulo: Revista dos Tribunais, 1992. p. 55. 
Pelo exposto, conclui-se, com André Janjácomo Rosilho ${ }^{272}$, que, no exercício da accountability financeira e orçamentária da Administração Pública, os agentes de accountability podem averiguar se os dispêndios realizados atenderam aos ditames legais, se os gastos foram legítimos e se os recursos públicos foram utilizados de forma a maximizar os resultados da atuação governamental.

Quanto às subvenções e renúncias de receitas, apesar de terem sido elencadas ao lado da legalidade, legitimidade e eficiência, elas não são propriamente aspectos quanto aos quais a fiscalização financeira e orçamentária deve ser realizada, mas são objetos de fiscalização.

Seu destaque no caput do artigo 70 da CRFB/1988, entre tantos objetos passíveis de fiscalização, segundo Ricardo Lobo Torres, teve o objetivo de coibir “[...] as manipulações e o encobrimento de incentivos fiscais, tão comuns na prática constitucional anterior [...]"273. Logo, os sujeitos ativos de accountability financeira e orçamentária não estão autorizados a descuidar de tais objetos ao exercerem o controle sobre a Administração.

As subvenções, conforme o artigo $12, \$ 3^{\circ}$, da Lei n. 4.320/1964, são transferências destinadas a cobrir despesas de custeio das beneficiadas, classificando-se em subvençôes sociais - que se destinam "[...] a instituiçôes públicas ou privadas de caráter assistencial ou cultural, sem finalidade lucrativa” - e subvenções econômicas - direcionadas a "[...] emprêsas públicas ou privadas de caráter industrial, comercial, agrícola ou pastoril" 274 . Como destaca Luiz Fernando Rodrigues Pinto Junior, as subvençôes “[...] constituem meios de cooperação financeira entre a União e entidades públicas ou privadas. A transferência é feita a fundo perdido, pretendendo atingir objetivos de interesse público, especialmente na área social, por intermédio de terceiros [...]"275.

Por outro lado, como ensina Celso de Barros Correia $\mathrm{Neto}^{276}$, a expressão renúncia de receitas está conectada aos incentivos fiscais em sentido estrito, designação atribuída a qualquer disposição especial de direito tributário que reduza a carga tributária, mediante alteração da obrigação principal, a fim de favorecer atividades privadas consentâneas com

${ }^{272}$ ROSILHO, André Janjácomo. Controle da administração pública pelo Tribunal de Contas da Uniáo. 2016. 358 f. Tese (Doutorado em Direito) - Departamento de Direito do Estado, Faculdade de Direito, Universidade de São Paulo, São Paulo, 2016. f. 156.

273 TORRES, Ricardo Lobo. Curso de direito financeiro e tributário. 20. ed. Rio de Janeiro: Renovar, 2018. p. 200

274 BRASIL. Lei n. 4.320, de 17 de março de 1964. Estatui Normas Gerais de Direito Financeiro para elaboração e contrôle dos orçamentos e balanços da União, dos Estados, dos Municípios e do Distrito Federal. Diário Oficial da União, Brasília, 23 mar. 1964. Disponível em: http://www.planalto.gov.br/ ccivil_03/leis/L4320.htm. Acesso em: 21 out. 2019.

275 PINTO JUNIOR, Luiz Fernando Rodrigues. Fiscalização patrimonial da administração pública. 2013. 303 f. Dissertação (Mestrado em Direito) - Departamento de Direito Econômico, Financeiro e Tributário, Faculdade de Direito, Universidade de São Paulo, São Paulo, 2013. p. 191.

276 CORREIA NETO, Celso de Barros. O avesso do tributo: incentivos e renúncias fiscais no direito brasileiro. 2. ed. São Paulo: Almedina, 2016. p. 132. 


\section{-• Contas dos governantes}

o interesse público. Trata-se, conforme Francisco Carlos Ribeiro de Almeida ${ }^{277}$, da utilização de tributo com finalidade extrafiscal, com o objetivo de (i) incentivar o desenvolvimento de determinadas regióes ou ativos financeiros; (ii) desenvolver segmentos econômicos estratégicos; (iii) estimular determinado comportamento do contribuinte; ou (iv) proporcionar alívio financeiro a determinados grupos sociais carentes.

Embora as subvenções e as renúncias de receita sejam institutos jurídicos distintos, de acordo com Elcio Fiori Henriques, “[...] economicamente, o resultado financeiro para o Estado e para o particular dessas duas figuras são semelhantes" ${ }^{278}$, na medida em que ambos representam uma vantagem financeira ao particular, sem exigência de contraprestação. A diferença principal, defende ele, é que na subvenção há "[...] efetiva transferência de recursos das contas do Tesouro, enquanto na segunda [renúncia de receita] os valores apenas deixam de ser recolhidos ao Erário" 279 , exigindo, portanto, diferentes formas de accountability financeira e orçamentária para cada modalidade.

O controle é diferente, também, porque, como destaca Elcio Fiori Henriques ${ }^{280}$, enquanto as subvenções passam por escrutínio anual do parlamento, via processo de elaboração do orçamento - momento adequado para juízos sobre a necessidade e a conveniência de sua prorrogação -, os benefícios fiscais que acarretam renúncia de receitas são aprovados por leis tributárias, sem custo aparente, tantas vezes sem prazo definido e sem revisão periódica orçamentária.

Desse modo, os agentes de accountability devem realizar a fiscalização orçamentária e financeira sobre as subvenções e as renúncias de receita ${ }^{281}$, com o intuito de averiguar se cumprem as finalidades legítimas para as quais tenham sido instituídas. Portanto, para verificar se permanecem atendendo ao interesse público, de modo a evitar que se transformem em benesses eternas, simples forma de transferência de renda do Estado para grupos privilegiados.

277 ALMEIDA, Francisco Carlos Ribeiro de. Uma abordagem estruturada da renúncia de receita pública federal. Revista do Tribunal de Contas da União, Brasília, v. 31, n. 84, p. 19-62, abr./jun. 2000. p. 23.

278 HENRIQUES, Elcio Fiori. O regime jurídico do gasto tributário no direito brasileiro. 2009. $221 \mathrm{f}$. Dissertação (Mestrado em Direito) - Departamento de Direito Econômico, Financeiro e Tributário, Faculdade de Direito, Universidade de São Paulo, 2009. p. 19.

279 HENRIQUES, Elcio Fiori. O regime jurídico do gasto tributário no direito brasileiro. 2009. $221 \mathrm{f}$. Dissertação (Mestrado em Direito) - Departamento de Direito Econômico, Financeiro e Tributário, Faculdade de Direito, Universidade de São Paulo, 2009. p. 21.

280 HENRIQUES, Elcio Fiori. O regime jurídico do gasto tributário no direito brasileiro. 2009. $221 \mathrm{f}$. Dissertação (Mestrado em Direito) - Departamento de Direito Econômico, Financeiro e Tributário, Faculdade de Direito, Universidade de São Paulo, 2009. p. 21-23.

281 A respeito dos mecanismos de controle dos incentivos fiscais, cf. CORREIA NETO, Celso de Barros. O avesso do tributo: incentivos e renúncias fiscais no direito brasileiro. 2. ed. São Paulo: Almedina, 2016. p. 215-283; e FERNANDES, Andressa Guimarães Torquato. Limitações ao controle interno para a fiscalização de benefícios fiscais em face do sigilo fiscal. In: BLIACHERIENE, Ana Carla; BRAGA, Marcus Vinicius de Azevedo; RIBEIRO, Renato Jorge Brown (Coord.). Controladoria no setor público. 2. ed. Belo Horizonte: Fórum, 2019. p. 350-353. 
Por conseguinte, conclui-se que a fiscalização financeira e orçamentária da Administração Pública deve ser efetuada, pelos agentes de accountability financeira e orçamentária, tendo em conta os aspectos da legalidade, da legitimidade e da economicidade, na forma apresentada nesta seção. As seções seguintes, deste trabalho, dedicam-se ao modelo do sistema de accountability financeira e orçamentária, instituído na CRFB/1988, e aos seus sujeitos ativos.

\subsection{CONTROLE INTERNO E CONTROLE EXTERNO}

O sistema de accountability financeira e orçamentária adotado por uma comunidade - que pode ser nacional, subnacional ou supranacional - define o modo e a quem os representantes, inclusive os governantes, devem prestar contas a respeito da gestão financeira e orçamentária dos recursos públicos a seu encargo. Tal sistema, nos termos utilizados por Heloisa Tartarotti Camargo, engloba “[...] os procedimentos legais e burocráticos que permitem ao Parlamento, aos partidos políticos e a outros grupos organizados, representativos da sociedade, saber como e porque o dinheiro público está sendo gasto" ${ }^{282}$.

No Brasil, a fiscalização financeira e orçamentária da Administração Pública, como estabelece o caput do artigo 70 da CRFB/1988, deve ser exercida, concomitantemente, mediante controle interno e controle externo.

Dessa maneira, o legislador constituinte optou pelo que Eduardo Lobo Botelho Gualazzi $^{283}$ denominou sistema de controles mistos. Segundo ele, tal sistema reúne os controles de legitimidade - incluindo, em sua visão, o controle de legalidade e de constitucionalidade - e os controles de supervisão político-administrativa - incluindo os controles técnico, contábil, de gestão de planejamento e de coordenação, que atuam sob o mérito -, mas com destaque às questões programático-orçamentárias, sendo exercido em duas instâncias, a saber, controle interno e controle externo.

Nesse sistema, como explica, o controle interno é definido "[...] como aquele que a administração de cada um dos Poderes efetua interna corporis, tendo por objeto a autotutela permanente de legitimidade e mérito" ${ }^{284}$. Como assevera Hugo de Brito Machado, "o controle é interno quando realizado pelo próprio órgão gestor do recurso [...]"285.

282 CAMARGO, Heloisa Tartarotti. O aprimoramento da prestação de contas do governo através da fiscalização e avaliação: um estudo comparativo entre Canadá, Estados Unidos e Brasil. Revista de Informação Legislativa, Brasília, v. 29, n. 114, p. 503-548, abr./jun. 1992. p. 535.

283 GUALAZZI, Eduardo Lobo Botelho. Regime jurídico dos tribunais de contas. São Paulo: Revista dos Tribunais, 1992. p. 31.

284 GUALAZZI, Eduardo Lobo Botelho. Regime jurídico dos tribunais de contas. São Paulo: Revista dos Tribunais, 1992. p. 33.

285 MACHADO, Hugo de Brito. Finanças públicas: fiscalização financeira e orçamentária. In: MARTINS, Ives Gandra; MENDES, Gilmar; NASCIMENTO, Carlos Valder do. Tratado de direito financeiro. v. 2. São Paulo: Saraiva, 2013. p. 198. 


\section{•. Contas dos governantes}

Nesse sentido, Themístocles Brandão Cavalcanti observou que "Interno é aquele controle exercido pelos próprios órgãos superiores da administração, por meio de suas auditorias" 286 .

No Brasil ${ }^{287}$, atualmente ${ }^{288}$, por força do caput do artigo 70 da CRFB/1988, a fiscalização financeira e orçamentária da Administração Pública deve ser realizada pelo sistema de controle interno de cada poder. Por isso, Vitor Rolf Laubé explica que o controle interno "[...] se desenvolve no bojo de cada um dos poderes constituídos, por seus próprios órgãos técnicos [...]"289.

Assim, conforme adverte Regis Fernandes de Oliveira, cada um dos poderes Executivo, Legislativo e Judiciário, “[...] deve manter um sistema de controle individual, de acordo com suas características próprias e, ao mesmo tempo, integrar o sistema com o dos outros órgãos, a fim de que haja coordenação e uniformização [...]" ${ }^{\prime 290}$. Na verdade, em cada esfera federativa, não somente os poderes devem manter uma unidade encarregada pelo seu controle interno, mas também o ministério público, a defensoria pública e o tribunal de contas, onde houver.

Bem andou o constituinte ao exigir o controle interno independente em cada poder e órgão autônomo, pois, na verdade, se determinada unidade ou órgão, estando subordinada a um dos poderes, fosse encarregada do controle interno de todos eles, haveria considerável risco de interferência de um nos outros. Aliás, nesse caso, o controle seria externo em relação aos demais, não interno.

A CRFB/1988, em seu artigo 74, caput e incisos, dispôs sobre as finalidades do controle interno, do seguinte modo:

Art. 74. Os Poderes Legislativo, Executivo e Judiciário manterão, de forma integrada, sistema de controle interno com a finalidade de:

I - avaliar o cumprimento das metas previstas no plano plurianual, a execução dos programas de governo e dos orçamentos da União;

286 CAVALCANTI, Themístocles Brandão. O tribunal de contas - órgão constitucional - funções próprias e funçôes delegadas. Revista de Direito Administrativo, Rio de Janeiro, v. 109, p. 1-10, 1972. p. 6-7.

287 A respeito do sistema de controle interno exigido pela União Europeia, cf. LOCHAGIN, Gabriel Loretto. O controle financeiro interno no direito comunitário europeu. In: BLIACHERIENE, Ana Carla; BRAGA, Marcus Vinicius de Azevedo; RIBEIRO, Renato Jorge Brown (Coord.). Controladoria no setor público. 2. ed. Belo Horizonte: Fórum, 2019. p. 151-164.

288 A respeito da transformação histórica do controle interno da administração pública no Brasil, cf. BAL$\mathrm{BE}$, Ronald da Silva. Controle interno no Brasil: uma visão histórica. In: BLIACHERIENE, Ana Carla; BRAGA, Marcus Vinicius de Azevedo; RIBEIRO, Renato Jorge Brown (Coord.). Controladoria no setor público. 2. ed. Belo Horizonte: Fórum, 2019. p. 41-65.

289 LAUBÉ, Vitor Rolf. Considerações acerca da conformação constitucional do tribunal de contas. Revista de Informação Legislativa, Brasília, v. 29, n. 113, p. 307-326, jan./mar. 1992. p. 311.

290 OLIVEIRA, Regis Fernandes de. Curso de direito financeiro. 7. ed. São Paulo: Revista dos Tribunais, 2015. p. 721. 
II - comprovar a legalidade e avaliar os resultados, quanto à eficácia e eficiência, da gestão orçamentária, financeira e patrimonial nos órgãos e entidades da administração federal, bem como da aplicação de recursos públicos por entidades de direito privado;

III - exercer o controle das operações de crédito, avais e garantias, bem como dos direitos e haveres da União;

IV - apoiar o controle externo no exercício de sua missão institucional291.

Portanto, a fiscalização financeira e orçamentária realizada pelas unidades responsáveis pelo controle interno envolve o controle de legalidade, mas também o controle de resultados, devendo avaliar a eficiência, a eficácia e a efetividade das ações administrativas frente às metas definidas, especialmente aquelas definidas pelo parlamento, no processo legislativo-orçamentário.

Nesse sentido, Hely Lopes Meirelles defendia que o controle interno "[...] visa assegurar a regularidade da realização da receita e da despesa, possibilitando o acompanhamento da execução do orçamento, dos programas de trabalho, dos contratos, e a avaliação dos respectivos resultados" 292 , envolvendo o controle de legalidade, oportunidade e eficiência. Odete Medauar ${ }^{293}$ também indica o controle de legalidade e de resultados como finalidades do controle interno.

Renato Jorge Brown Ribeiro, Ana Carla Bliacheriene e José Lima Santana destacam a proximidade do controle interno com a gestão e o aspecto educativo de suas ações de controle. Segundo eles, "Toda política pública obedece a um ciclo, que tem no momento do controle uma oportunidade ímpar de qualificação e melhoria tanto de processos e fluxos quantos dos resultados palpáveis e entregues à sociedade" 294 .

De acordo com a INTOSAI ${ }^{295}$, o controle interno destina-se a fornecer uma garantia razoável de que o respectivo poder ou órgão (i) executa suas operações de forma ordenada, ética, econômica, eficiente e efetiva; (ii) cumpre suas obrigações de prestação de contas e accountability; (iii) cumpre as leis e os regulamentos aplicáveis às suas

291 BRASIL. Constituição (1988). Constituição da República Federativa do Brasil. Disponível em: http:// www.planalto.gov.br/ccivil_03/Constituicao/Constituicao.htm. Acesso em: 2 dez. 2019.

${ }^{292}$ MEIRELLES, Hely Lopes. A administração pública e seus controles. Revista de Direito Administrativo, Rio de Janeiro, n. 114, p. 23-33, out./dez. 1973. p. 31.

${ }^{293}$ MEDAUAR, Odete. Direito administrativo moderno. 20. ed. São Paulo: Revista dos Tribunais, 2016. p. 454 .

${ }^{294}$ RIBEIRO, Renato Jorge Brown; BLIACHERIENE, Ana Carla; SANTANA, José Lima. Considerações sobre formas, processos e isoformismo nas estruturas de controle interno da federação brasileira. In: BLIACHERIENE, Ana Carla; BRAGA, Marcus Vinicius de Azevedo; RIBEIRO, Renato Jorge Brown (Coord.). Controladoria no setor público. 2. ed. Belo Horizonte: Fórum, 2019. p. 30.

295 INTERNATIONAL ORGANIZATION OF SUPREME AUDIT INSTITUTIONS (INTOSAI). INTOSAI GOV 9100: guidelines for internal control standards for the public sector. Budapest: INTOSAI, 2004. Disponível em: https://www.issai.org/wp-content/uploads/2019/08/intosai_gov_9100_e. pdf. Acesso em: 22 out. 2019. p. 6. 


\section{•. Contas dos governantes}

atividades; e (iv) mantêm os recursos à sua disposição salvaguardados de perdas, má utilização e danos. Semelhantemente, para o United States Government Accountability Office - instituição responsável pelo controle externo da gestão financeira e orçamentária da Administração Pública federal nos Estados Unidos da América, ao lado do Congresso - "O controle interno [...] fornece uma garantia razoável de que os objetivos de uma entidade serão alcançados, [...] ajuda os gestores a alcançar os resultados desejados através da administração eficaz dos recursos públicos” ${ }^{296}$. Leonardo Rodrigues Albernaz e Marcelo Barros Gomes ${ }^{297}$ concluem no mesmo sentido.

José Mauricio Conti e André Castro Carvalho advertem, porém, que a função do controle interno "[...] não se confunde com as funções de controle administrativo do tipo 'autocontrole' ou mesmo de 'controle hierárquico' [...], sendo muito mais um instrumento de controle financeiro do que administrativo" 298 . Sobre sua necessidade e finalidades, manifestam-se do seguinte modo:

O controle interno é necessário para avaliar, medir e controlar as atividades do órgão da Administração Pública, de forma independente, prestando assessoria à alta administração. Tem a finalidade de constatar a eficiência, efetividade, eficácia, legalidade e legitimidade das atividades administrativas e financeiras exercidas pelos diversos componentes do órgão em questão, realizando o acompanhamento das políticas traçadas pelo gestor, e dar subsídios para correções, ajustes e aperfeiçoamentos voltados a atingir as metas, além de fornecer informações úteis e necessárias para a tomada de decisões ${ }^{299}$.

Para que possam prestar, como indicam, essa assessoria à alta administração de forma independente, eles defendem que "[...] a unidade de controle interno somente pode estar subordinada ao dirigente máximo do órgão, não sendo possível que integre a administração de forma que fique vinculada a qualquer outro órgão ou dirigente" ${ }^{300}$.

296 UNITED STATES GOVERNMENT ACCOUNTABILITY OFFICE (GAO). GAO 14-704G: The Green Book. Standards for Internal Control in the Federal Government. Washington: GAO, 2014. Disponível em: http://www.gao.gov/products/GAO-14-704G. Acesso em: 7 abr. 2017. p. 5 (tradução nossa).

297 ALBERNAZ, Leonardo Rodrigues; GOMES, Marcelo Barros. Governança pública e controle. In: BLIACHERIENE, Ana Carla; BRAGA, Marcus Vinicius de Azevedo; RIBEIRO, Renato Jorge Brown (Coord.). Controladoria no setor público. 2. ed. Belo Horizonte: Fórum, 2019. p. 125-126.

298 CONTI, José Mauricio; CARVALHO, André Castro. O controle interno na administração pública brasileira: qualidade do gasto público e responsabilidade fiscal. Direito Público, n. 37, p. 201-220, jan./ fev. 2011. p. 204-205.

299 CONTI, José Mauricio; CARVALHO, André Castro. O controle interno na administração pública brasileira: qualidade do gasto público e responsabilidade fiscal. Direito Público, n. 37, p. 201-220, jan./ fev. 2011. p. 207.

300 CONTI, José Mauricio; CARVALHO, André Castro. O controle interno na administração pública brasileira: qualidade do gasto público e responsabilidade fiscal. Direito Público, n. 37, p. 201-220, jan./ fev. 2011. p. 210 
Nesse sentido, na histórica Declaração de Lima de 1977, a INTOSAI firmou que "Os serviços de auditoria interna estão necessariamente subordinados ao chefe do departamento no qual foram estabelecidos. No entanto, devem ser funcionalmente e organizacionalmente independentes [...]"301.

A atividade de controle interno, segundo José Mauricio Conti e André Castro Carvalho, tem "[...] um caráter de accountability horizontal [...]"302. Com tal afirmação, quiseram dizer os autores que as unidades de controle interno funcionam como sujeitos ativos de accountability horizontal.

Deve-se ter em mente, contudo, considerando o conceito de accountability apresentado na seção 1.4 (p. 51) deste trabalho, que tal relação de accountability não seria decorrente da relação de agência existente entre a população e o governante, mas de uma relação de agência secundária formada entre este e os agentes públicos aos quais o governante, considerando a impossibilidade de sozinho dar conta de todas as atribuiçôes que lhe são outorgadas, delega a execução das atividades administrativas.

Nesse sentido, os agentes públicos, aos quais os chefes de poder ou órgão autônomo delegaram parte de suas atribuições, devem prestar contas às unidades de controle interno. Estas, por sua vez, identificando eventual situação punível, têm a capacidade de apresentá-la ao titular do poder ou órgão, que detém a capacidade direta de punição, como a demissão.

Como o sujeito ativo da relação de accountability descrita pertence à estrutura estatal, na classificação de Guillermo O’Donnell, apresentada na seção 1.5 (p. 57) deste trabalho, ela enquadra-se como accountability horizontal.

Entre as finalidades do controle interno, como previsto no artigo 74, inciso IV, da CRFB/1988, está o apoio ao controle externo. Conforme se depreende do $\$ 1^{\circ}$ do artigo 74 da Constituição, tal apoio envolve, mas não se limita, a obrigação, que os responsáveis pelo controle interno têm, de informar ao tribunal de contas competente a respeito de qualquer irregularidade ou ilegalidade de que tomem conhecimento, sob pena de serem considerados solidários na responsabilidade pelo evento punível. Fernando Bessa de Almeida ${ }^{303}$ e Hely Lopes Meirelles ${ }^{304}$ destacaram a importância do

301 INTERNATIONAL ORGANIZATION OF SUPREME AUDIT INSTITUTIONS (INTOSAI). INTOSAI Principles. INTOSAI Founding Principles. INTOSAI-P 1: The Lima declaration. Lima: INTOSAI, 1977. Disponível em: https://www.issai.org/pronouncements/intosai-p-1-the-lima-declaration/. Acesso em: 17 out. 2019. p. 8 (tradução nossa).

302 CONTI, José Mauricio; CARVALHO, André Castro. O controle interno na administração pública brasileira: qualidade do gasto público e responsabilidade fiscal. Direito Público, n. 37, p. 201-220, jan./ fev. 2011. p. 205.

303 ALMEIDA, Fernando Bessa de. A fiscalização financeira e orçamentária na Constituição de 1967. Revista de Administração Pública, Rio de Janeiro, n. 1, p. 103-143, 1967. p. 126.

304 MEIRELLES, Hely Lopes. A administração pública e seus controles. Revista de Direito Administrativo, Rio de Janeiro, n. 114, p. 23-33, out./dez. 1973. p. 31. 


\section{•. Contas dos governantes}

salutar apoio do controle interno ao controle externo, e a integração daí resultante. Como registram Antonio Alves de Carvalho Neto et al. ${ }^{305}$, a complementariedade entre suas atividades é um consenso.

Esse canal de comunicação, mais que uma obrigação, reforça a capacidade indireta da unidade de controle interno para a punição dos sujeitos passivos de accountability, uma vez que os tribunais de contas detêm capacidade - direta ou indireta, conforme o caso - de aplicar sanções àqueles que lhe devem prestar contas. Tal capacidade, vale relembrar, é essencial para a configuração da relação de accountability, conforme conceito adotado neste trabalho, apresentado na seção 1.4 (p. 51).

Enquanto o controle interno é realizado por órgão ou unidade topograficamente localizado na mesma estrutura do agente controlado, o controle externo é aquele exercido por outros órgãos, que não integram a estrutura do próprio sujeito passivo da accountability.

Nesse sentido, Celso Antônio Bandeira de Mello identifica o controle externo como aqueles "[...] controles de legitimidade que devem ser efetuados por outros braços do Estado: Legislativo, por si próprio ou com auxílio do Tribunal de Contas, e Judiciário, este atuando sob provocação dos interessados ou do Ministério Público"306. Sob a égide da constituição anterior, Caio Tácito ${ }^{307}$ e Hely Lopes Meirelles ${ }^{308}$ destacaram, como manutenção da tradição constitucional, a previsão dos controles administrativo, parlamentar e judicial.

Sob a égide da CRFB/1988, como leciona Odete Medauar, o controle externo, segundo a sua titularidade, pode ser "[...] realizado por instituiçôes políticas, por instituiçôes técnicas e por instituiçôes precipuamente jurídicas”309. Na ótica de Cláudio Ferreira ${ }^{310}$, o controle externo realizado por instituições políticas seria o controle parlamentar, o efetuado por instituições técnicas seria aquele a cargo dos tribunais de contas e efetivado por instituições precipuamente jurídicas seria o da alçada do Poder Judiciário.

Este último, o controle externo a cargo do Poder Judiciário - denominado ainda como controle jurisdicional da Administração Pública, controle judiciário ou controle

305 CARVALHO NETO, Antonio Alves de et al. Sistema de Controle Interno da Administração Pública na Uniáo Europeia e no Brasil. Belo Horizonte: Fórum, 2019. p. 95.

306 MELLO, Celso Antônio Bandeira de. Curso de direito administrativo. 33. ed. São Paulo: Malheiros, 2016. p. 965.

307 TÁCITO, Caio. O controle da administração e a nova constituição do Brasil. Revista de Direito Administrativo, Rio de Janeiro, v. 90, p. 23-29, 1967. p. 25.

308 MEIRELLES, Hely Lopes. A administração pública e seus controles. Revista de Direito Administrativo, Rio de Janeiro, n. 114, p. 23-33, out./dez. 1973. p. 23.

309 MEDAUAR, Odete. Direito administrativo moderno. 20. ed. São Paulo: Revista dos Tribunais, 2016. p. 444.

310 FERREIRA, Cláudio. O julgamento das contas públicas e o sistema de controle parlamentar do Governo na Constituição brasileira de 1988. 2011. 161 f. Dissertação (Mestrado em Direito) - Departamento de Direito do Estado, Faculdade de Direito, Universidade de São Paulo, São Paulo, 2011. f. 50-51. 
judicial -, segundo Odete Medauar, “[...] abrange a apreciação, efetuada pelo Poder Judiciário, sobre atos, processos e contratos administrativos ou operações materiais e mesmo a omissão ou inércia da Administração"311. Segundo ela,

O controle jurisdicional caracteriza-se como controle externo, de regra a posteriori, repressivo ou corretivo, podendo apresentar conotação preventiva. É desencadeado por provocação (não existe jurisdição sem autor) e efetuado por juízes dotados de independência. Esse controle se realiza pelo ajuizamento de açóes, que observam procedimentos formais, com garantias às partes, tais como juiz natural, imparcialidade, contraditório, ampla defesa, dentre outras. O processo se encerra por sentença, obrigatoriamente motivada e dotada da autoridade da coisa julgada, impondo-se, portanto, à Administração, que deve acatá-la ${ }^{312}$.

Seus instrumentos, previstos na CRFB/1988, conforme Celso Antônio Bandeira de Mello ${ }^{313}$, Hely Lopes Meirelles ${ }^{314}$, Odete Medauar ${ }^{315}$ e José dos Santos Carvalho Filho ${ }^{316}$, incluem: a) o habeas corpus: artigo $5^{\circ}$, inciso LXVIII; b) o mandado de segurança individual e coletivo: incisos LXIX e LXX do artigo $5^{\circ}$; c) o habeas data: o artigo 5º inciso LXXII; d) o mandado de injunção: artigo 5º, inciso LXXI; e) a ação popular: inciso LXXIII do artigo 5; f) a ação civil pública: artigo 129, inciso I; g) a ação de improbidade administrativa: artigo $37, \$ 4^{\circ}$; e h) a ação direta de inconstitucionalidade (ADI), a ação declaratória de constitucionalidade (ADC), a arguição de descumprimento de preceito fundamental (ADPF) e a ação de inconstitucionalidade por omissão: artigos 102, inciso I, alínea “a”, 103, 102, $\$ 1$ o, e 103, $\$ 2$ o.

A provocação ocorre, segundo Luiz Fernando Rodrigues Pinto Junior, pelo “[...] Ministério Público nas questões coletivas e referentes à Administração Pública, por entidades de caráter coletivo e social ou ainda outros órgãos como Defensoria Pública, Advocacia Geral da União e similares"317. Hely Lopes Meirelles destacava que tal controle externo, a cargo do Judiciário, “[...] visa à defesa dos administrados e à manuten-

311 MEDAUAR, Odete. Direito administrativo moderno. 20. ed. São Paulo: Revista dos Tribunais, 2016. p. 460 .

312 MEDAUAR, Odete. Direito administrativo moderno. 20. ed. São Paulo: Revista dos Tribunais, 2016. p. 460

313 MELLO, Celso Antônio Bandeira de. Curso de direito administrativo. 33. ed. São Paulo: Malheiros, 2016. p. 985-989.

314 MEIRELLES, Hely Lopes. Direito administrativo brasileiro. 43. ed. São Paulo: Malheiros, 2018. p. 889-903.

315 MEDAUAR, Odete. Direito administrativo moderno. 20. ed. São Paulo: Revista dos Tribunais, 2016. p. 473-488.

316 CARVAlHO FILHO, José dos Santos. Manual de direito administrativo. 33. ed. São Paulo: Atlas, 2019. p. 1102-1187.

317 PINTO JUNIOR, Luiz Fernando Rodrigues. Fiscalização patrimonial da administração pública. 2013. 303 f. Dissertação (Mestrado em Direito) - Departamento de Direito Econômico, Financeiro e Tributário, Faculdade de Direito, Universidade de São Paulo, São Paulo, 2013. p. 108-109. 


\section{•. Contas dos governantes}

ção da Administração dentro das normas legais [...]"318. Para tanto, sua competência abrangeria "[...] não só a conformação do ato com a lei, como também com a moral administrativa e com o interesse coletivo, indissociável de toda atividade pública"319.

Embora seja uma espécie de controle externo, como bem destacam os administrativistas citados, e se posicione entre os instrumentos de accountability elencados por Fernando Luiz Abrucio e Maria Rita Loureiro ${ }^{320}$, o controle judicial visa precipuamente à manutenção do império da lei, e não especificamente à accountability financeira e orçamentária da Administração Pública. Por isso, embora disponha dos instrumentos de controle elencados nesta seção, o Poder Judiciário não foi previsto como um dos atores do controle externo previsto na Seção IX - Da fiscalização contábil, financeira e orçamentária - do Capítulo I - Do Poder Legislativo - do Título IV - Da organização dos poderes - da CRFB/1988 ${ }^{321}$.

Da leitura conjunta das cabeças dos artigos 70 e 71 da CRFB/1988, percebe-se que, no que se refere à fiscalização financeira e orçamentária da Administração Pública brasileira, o controle externo deve ser exercido pelo parlamento, seu titular histórico, com o auxílio de um tribunal de contas.

Considerando que tanto o Poder Legislativo como as cortes de contas são órgãos pertencentes à estrutura estatal, a fiscalização financeira e orçamentária realizada por eles, mediante controle externo, também se enquadra como accountability horizontal, na classificação de Guillermo O’Donnell, apresentada na seção 1.5 (p. 57) deste trabalho.

Nesse âmbito, para José Afonso da Silva, o controle externo tem como objetivos "[...] verificar da legalidade, da legitimidade e da economicidade dos atos contábeis, financeiros, orçamentários, operacionais e patrimoniais da administração direta e indireta da Uniāo" 322 . Ao tratar do controle externo da execução orçamentária realizado pelo Poder Legislativo, a Lei n. 4.320/1964, em seu artigo 81, estabeleceu que sua fi-

318 MEIRELLES, Hely Lopes. A administração pública e seus controles. Revista de Direito Administrativo, Rio de Janeiro, n. 114, p. 23-33, out./dez. 1973. p. 23-24.

319 MEIRELLES, Hely Lopes. A administração pública e seus controles. Revista de Direito Administrativo, Rio de Janeiro, n. 114, p. 23-33, out./dez. 1973. p. 24.

320 ABRUCIO, Fernando Luiz; LOUREIRO, Maria Rita. Finanças públicas, democracia e accountability. In: ARVATE, Paulo Roberto; BIDERMAN, Ciro (Org.). Economia do setor público no Brasil. Rio de Janeiro: Elsevier/Campus, 2004. p. 84.

321 A respeito da atuação específica do Conselho Nacional de Justiça - que, também, não é um dos atores do sistema constitucional de accountability financeira e orçamentária da Administração Pública -, como agente de accountability judicial interno, cf. TOMIO, Fabrício Ricardo de Limas; ROBL FILHO, Ilton Norberto. Accountability e independência judiciais: uma análise da competência do Conselho Nacional de Justiça (CNJ). Revista de Sociologia e Política, Curitiba, v. 21, n. 45, p. 29-46, mar. 2013. Disponível em: https://revistas.ufpr.br/rsp/article/view/34439/21357. Acesso em: 25 nov. 2019. p. 36-44.

322 SILVA, José Afonso da. Curso de direito constitucional positivo. 40. ed. São Paulo: Malheiros, 2017. p. 766. 
nalidade é "[...] verificar a probidade da administração, a guarda e legal emprêgo dos dinheiros públicos e o cumprimento da Lei de Orçamento" ${ }^{\text {"23 }}$.

Veja-se que a afluência das tradições republicana - manifesta na preocupação com a probidade e adequada destinação dos recursos públicos - e democrática - perceptível no apego à escolha democrática efetuada por meio do orçamento - é sensível na redação do dispositivo, como, aliás, ocorre em toda a temática do controle externo da gestão financeira e orçamentária da Administração Pública.

No mesmo sentido, Hely Lopes Meirelles afirmava que "O controle externo visa comprovar a probidade da Administração e a regularidade da guarda e do emprego dos bens, valores e dinheiros públicos, e a fiel execução do orçamento" ${ }^{24}$. Ele destacava a existência de um aspecto político e outro técnico no controle externo, o primeiro reservado ao parlamento e o segundo delegado aos tribunais de contas.

Desse modo, considerando que este trabalho se insere no âmbito da accountability financeira e orçamentária da Administração Pública, cujo papel atribuído ao Poder Judiciário é secundário, subsidiário, as seções seguintes se ocupam do controle externo exercido pelo Poder Legislativo e pelas cortes de contas, nessa ordem.

\subsection{CONTROLE EXTERNO PELO PODER LEGISLATIVO}

Em países, como o Brasil, que adotaram o regime presidencialista de governo, com eleição direta para chefe do Poder Executivo, formam-se relações diretas de agência tanto entre o governante e os eleitores como entre estes e os parlamentares.

$\mathrm{Na}$ primeira relação, entre governante eleito, que exerce o papel de agente, e governados eleitores, principais da relação, aquele deve governar no interesse destes, enquanto estes exercem a accountability vertical sobre aqueles, principalmente por meio do voto, nas eleiçóes. Contudo, verificada a insuficiência dos instrumentos de accountability vertical - vide subseção 1.5 .1 (p. 58) deste trabalho - e a necessidade de implementar mecanismos de accountability horizontal - conforme a subseção 1.5.2 (p. 62) -, torna-se forçoso incluir na segunda relação direta de agência, formada entre os cidadãos, principais da relação, e os parlamentares, que exercem o papel de agentes, o dever de estes agirem no interesse daqueles, não só para legislar, mas também controlar a Administração Pública.

Desse modo, considerando o conceito apresentado na seção 1.4 (p. 51), conclui-se que, a partir desta última relação de agência, entre cidadãos e parlamentares, formam-

323 BRASIL. Lei n. 4.320, de 17 de março de 1964. Estatui Normas Gerais de Direito Financeiro para elaboração e contrôle dos orçamentos e balanços da União, dos Estados, dos Municípios e do Distrito Federal. Diário Oficial da União, Brasília, 23 mar. 1964. Disponível em: http://www.planalto.gov.br/ ccivil_03/leis/L4320.htm. Acesso em: 21 out. 2019.

324 MEIRELLES, Hely Lopes. A administração pública e seus controles. Revista de Direito Administrativo, Rio de Janeiro, n. 114, p. 23-33, out./dez. 1973. p. 31. 


\section{•. Contas dos governantes}

-se duas relações de accountability. Na primeira, vertical, os parlamentares eleitos são responsáveis perante os eleitores. Na segunda, os membros do Poder Legislativo funcionam como agentes de accountability horizontal perante a Administração Pública.

Nos países que adotam o sistema parlamentarista de governo, embora existam algumas diferenças na formação das relações de agência, o funcionamento das relações de accountability, em teoria, é semelhante. Vale dizer, nos sistemas parlamentaristas, como nos presidencialistas, embora usualmente os governantes não sejam escolhidos pelo voto majoritário direto dos cidadãos - pois os governos são normalmente formados em decorrência da composição do parlamento resultantes das eleições -, também há a formação de uma óbvia relação de agência entre os parlamentares e os cidadãos e de outra, não tão óbvia, entre os cidadãos e os governantes, que devem agir no interesse daqueles, não no interesse dos parlamentares.

Nesses casos, persistem tanto as duas relações de accountability vertical - exercendo os papéis de agentes os governantes, numa, e os parlamentares, noutra, e de principais os cidadãos, em ambas - como a relação de accountability horizontal entre o Legislativo e o governo, este como agente e aquele como principal. Deve-se destacar que, nos sistemas parlamentaristas, esta relação de accountability horizontal é reforçada pela capacidade que, normalmente, detém o parlamento de demissão dos membros do gabinete.

Em ambos os casos, seja no presidencialismo, seja no parlamentarismo, o mandato que os cidadãos outorgam aos membros do parlamento, representantes por excelência da população, envolve sua representação tanto para elaborar as leis como para exercer o controle externo da gestão financeira e orçamentária da Administração Pública. Nesse sentido, Charles Pessanha ${ }^{325}$ e María Esther Seijas Villadangos ${ }^{326}$ destacam a atribuição de controle do Poder Legislativo, com tanta importância quanto a ordenação política por meio da legislação.

Ao tratar do sistema de controle parlamentar sobre o governo no Brasil, Cláudio Ferreira classifica-o em duas espécies, a saber, o poder de controle e a função de controle ${ }^{327}$. Segundo ele, o poder de controle - controle primário - tem caráter político, porque

325 PESSANHA, Charles. Controle externo: a função esquecida do legislativo no Brasil. In: SCHWARTZMAN, Luisa Farah; SCHWARTZMAN, Isabel Farah; SCHWARTZMAN, Felipe Farah; SCHWARTZMAN, Michel Lent (Org.). O sociólogo e as políticas públicas. Rio de Janeiro: Fundação Getúlio Vargas, 2009. p. 245.

326 SEIJAS VILLADANGOS, María Esther. La centralidade del parlamento. Una teoría crítica de sus funciones. Revista Brasileira de Direito, Passo Fundo, v. 14, n. 3, p. 24-54, set./dez. 2018. DOI: 10.18256/2238-0604.2018.v14i3.2973. p. 31-34.

327 Ao que Cláudio Ferreira denomina "poder de controle" e "função de controle", outros autores chamam "controle político" e "poder financeiro", respectivamente, cf. FAGUNDES, Tatiana Penharrubia. O controle das contas municipais. 2012. 273 f. Tese (Doutorado em Direito) - Departamento de Direito do Estado, Faculdade de Direito, Universidade de São Paulo, São Paulo, 2012. p. 137. 
expressa uma opinião política. Desse modo, tendo “[...] por fundamento unicamente a opinião, é exclusivo do Parlamento" 328 , que não pode delegá-lo.

O poder de controle é, conforme José Levi Mello do Amaral Júnior “[...] uma das mais antigas e marcantes funções dos Parlamentos em geral e do Congresso Nacional brasileiro em particular [...]"329. Em seu exercício, o Legislativo impõe limites à atuação estatal, determina expressamente as providências a serem tomadas ou estabelece genericamente os objetivos a serem perseguidos, conforme destaca Cláudio Ferreira ${ }^{330}$.

Como explica, o Poder Legislativo é chamado a exercer o poder de controle "[...] nas situações previstas na própria Constituição, sempre que houver determinação de que a atividade pretendida pelo Governo só pode ser concretizada se for submetida ao Parlamento e se dele obtiver a aquiescência" ${ }^{331}$. Portanto, entre outras situações previstas na CRFB/1988, é o poder de controle que se manifesta quando o parlamento elabora e aprova as leis do ciclo orçamentário - plano plurianual (PPA), leis de diretrizes orçamentárias (LDO) e lei orçamentária anual (LOA) - e os planos e programas nacionais, regionais e setoriais de desenvolvimento.

Por outro lado, Cláudio Ferreira esclarece que a função de controle - controle secundário - tem caráter legal, não só político, pois atua como um “[...] instrumento de manutenção ou de restabelecimento da ordem jurídica" ${ }^{332}$. Como seu caráter não é estritamente político, seu exercício não precisa ser exclusividade do parlamento, de forma que pode ser dividido com outros órgãos, aos quais a constituição do Estado atribua competências para o controle da Administração Pública.

A função de controle, segundo o autor, opera "[...] no acompanhamento da implementação das medidas necessárias à obtenção dos resultados estabelecidos como meta e também na aferição do que se fez em contraste com o que deveria ter sido feito"333. Por

328 FERREIRA, Cláudio. O julgamento das contas públicas e o sistema de controle parlamentar do Governo na Constituição brasileira de 1988. 2011. 161 f. Dissertação (Mestrado em Direito) - Departamento de Direito do Estado, Faculdade de Direito, Universidade de São Paulo, São Paulo, 2011. f. 47.

329 AMARAL JÚNIOR, José Levi Mello do. O Poder Legislativo na democracia contemporânea: a função de controle político dos parlamentos na democracia contemporânea. Revista de Informação Legislativa, Brasília, v. 42, n. 168, p. 7-18, out./dez. 2005. p. 7.

330 FERREIRA, Cláudio. O julgamento das contas públicas e o sistema de controle parlamentar do Governo na Constituição brasileira de 1988. 2011. 161 f. Dissertação (Mestrado em Direito) - Departamento de Direito do Estado, Faculdade de Direito, Universidade de São Paulo, São Paulo, 2011. f. 47.

331 FERREIRA, Cláudio. O julgamento das contas públicas e o sistema de controle parlamentar do Governo na Constituição brasileira de 1988. 2011. 161 f. Dissertação (Mestrado em Direito) - Departamento de Direito do Estado, Faculdade de Direito, Universidade de São Paulo, São Paulo, 2011. f. 47.

332 FERREIRA, Cláudio. O julgamento das contas públicas e o sistema de controle parlamentar do Governo na Constituição brasileira de 1988. 2011. 161 f. Dissertação (Mestrado em Direito) - Departamento de Direito do Estado, Faculdade de Direito, Universidade de São Paulo, São Paulo, 2011. f. 46-47.

333 FERREIRA, Cláudio. O julgamento das contas públicas e o sistema de controle parlamentar do Governo na Constituição brasileira de 1988. 2011. 161 f. Dissertação (Mestrado em Direito) - Departamento de Direito do Estado, Faculdade de Direito, Universidade de São Paulo, São Paulo, 2011. f. 50. 


\section{-• Contas dos governantes}

isso, se a elaboração do orçamento, com a previsão das receitas e a fixação das despesas, pelos representantes do povo foi uma das conquistas fundamentais da democracia, Alfredo Buzaid destacou que sua execução deveria ser fiscalizada pelo mesmo corpo legislativo que o aprovou, caso contrário, "[...] prestar-se-ia facilmente à fraude, mediante estorno de verbas, malversação do dinheiro público e desvio de recursos além das raias estabelecidas para as despesas"334. De fato, como destaca Odete Medauar ${ }^{335}$, hoje, no Ocidente ${ }^{336}$, a função de controle sobre o Executivo é inerente ao parlamento.

Pelo exposto, conclui-se que, ao agir como sujeito ativo de accountability horizontal em relação ao Poder Executivo, no exercício da accountability financeira e orçamentária da Administração Pública, o Congresso Nacional, as assembleias legislativas, as câmaras de vereadores e a Câmara Legislativa do DF, inclusive as comissões dessas casas, exercem função de controle, não poder de controle.

Segundo defendia Hely Lopes Meirelles ${ }^{337}$, tendo como foco a accountability financeira e orçamentária, tal controle não deve se ocupar dos direitos individuais do administrado, mas deve se voltar aos interesses coletivos da comunidade.

Como forma de operacionalizar o controle parlamentar direto da União, a CRFB/1988, em seu artigo 166, $\$ 1^{\circ}$, previu a existência, no Congresso Nacional, de uma comissão mista permanente formada por senadores e deputados. Atualmente, quem exerce essa função é a CMO, que, conforme o artigo 2o de seu Regulamento interno, é formada por sessenta e três deputados federais e vinte e um senadores.

Suas atividades envolvem tanto o exercício do poder de controle quanto da função de controle. Exerce poder de controle, por exemplo, quando, na forma dos incisos I e II do referido $\$ 1^{\circ}$ do artigo 166 da CRFB/1988, examina e emite parecer sobre os projetos de lei do plano plurianual, de diretrizes orçamentárias, do orçamento anual, e sobre os planos e programas nacionais, regionais e setoriais. Por outro lado, na forma dos mesmos dispositivos, exerce função de controle, verbi gratia, quando examina e emite parecer sobre as contas apresentadas, anualmente, pelos presidentes da República e quando exerce o acompanhamento e a fiscalização orçamentária.

Para se ter uma ideia sobre as atividades exercidas pela $\mathrm{CMO}$, tomando, por exemplo, apenas o acompanhamento e a fiscalização da execução orçamentária e fi-

334 BUZAID, Alfredo. O tribunal de contas no Brasil. Revista da Faculdade de Direito da Universidade de São Paulo, São Paulo, v. 62, n. 2, p. 37-62, 1967. p. 38-39.

335 MEDAUAR, Odete. Controle parlamentar da administração. Revista de Informação Legislativa, Brasília, v. 27, n. 107, p. 111-130, jul./set. 1990. p. 113.

336 A respeito do controle parlamentar da administração pública na França, na Inglaterra e nos Estados Unidos da América, cf. MEDAUAR, Odete. Controle parlamentar da administração. Revista de Informação Legislativa, Brasília, v. 27, n. 107, p. 111-130, jul./set. 1990. p. 115-123. A respeito dos modelos de controle parlamentar existentes nos países ocidentais, cf. GUALAZZI, Eduardo Lobo Botelho. Regime jurídico dos tribunais de contas. São Paulo: Revista dos Tribunais, 1992. p. 34-36.

337 MEIRELLES, Hely Lopes. A administração pública e seus controles. Revista de Direito Administrativo, Rio de Janeiro, n. 114, p. 23-33, out./dez. 1973. p. 24-25. 
nanceira e da gestão fiscal, conforme o artigo $1^{\circ}$, inciso III, de seu Regulamento interno, a Comissão examina e emite parecer sobre (i) os relatórios de gestão fiscal; (ii) sobre as informações encaminhadas ao Congresso Nacional pelo TCU ou por órgãos e entidades da Administração federal; (iii) sobre os relatórios referentes aos atos de limitação de empenho e movimentação financeira; (iv) sobre os demais relatórios de acompanhamento da execução orçamentária e financeira, nos termos da LDO; e (v) sobre as informações prestadas pelo Poder Executivo ao Congresso Nacional. Para o exercício de suas competências, seu Regulamento, apoiado na CRFB/1988, prevê no artigo $1^{\circ}, \$ 2^{\circ}$, que a $\mathrm{CMO}$ poderá:

Art. 1o A Comissão Mista de Planos, Orçamentos Públicos e Fiscalização tem por competência:

$[\ldots]$

$\$ 2^{\circ}$ Para o exercício das competências mencionadas neste artigo a Comissão poderá:

I - solicitar ao Tribunal de Contas da União a realização de inspeçôes e auditorias, bem como requisitar informações sobre a fiscalização contábil, financeira, orçamentária, operacional e patrimonial e sobre resultados de auditorias e inspeçôes realizadas;

II - requerer informações e documentos de órgãos e entidades federais;

III - realizar audiências públicas com representantes de órgãos e entidades públicas e da sociedade civil;

IV - promover inspeções e diligências em órgãos da administração pública federal, bem como junto a órgãos das administraçôes estadual e municipal que recebam recursos a título de transferência voluntária e entidades privadas que recebam recursos do orçamento da União a título de transferência, como subvenção, auxílio ou contribuição, ou que administre bens da União;

$\mathrm{V}$ - solicitar à autoridade governamental responsável que preste os esclarecimentos necessários, no prazo de cinco dias, diante de indícios de despesas não autorizadas, ainda que sob a forma de investimentos não programados ou de subsídios não aprovados;

VI - pedir ao Tribunal de Contas da União que se pronuncie conclusivamente, no prazo de trinta dias, sobre a matéria referida no inciso anterior, caso não sejam prestados os esclarecimentos ou estes forem considerados insuficientes;

VII - propor ao Congresso Nacional a sustação da despesa referida no inciso V, se julgar que o gasto possa causar dano irreparável ou grave lesão à economia pública $^{338}$.

338 BRASIL. Congresso Nacional. Comissão Mista de Planos, Orçamentos Públicos e Fiscalização. Regulamento interno. Disponível em: http://www.camara.leg.br/internet/comissao/index/mista/orca/Legisla_CMO/Regulamento_interno_CMO.pdf. Acesso em: 23 out. 2019. p. 3-4. 
Não satisfeitas apenas com a existência da CMO, no âmbito federal, cada casa do Congresso Nacional criou uma comissão permanente, cujas atribuições envolvem a accountability da gestão financeira e orçamentária da Administração Pública, mediante controle externo. A Câmara dos Deputados criou a Comissão de Fiscalização Financeira e Controle, cujas atribuições estão previstas no artigo 32, inciso XI, do regimento interno da Câmara ${ }^{339}$, e o Senado Federal mantém a Comissão de Transparência, Governança, Fiscalização e Controle e Defesa do Consumidor, cujas competências foram enumeradas no artigo 102-A do regimento interno do Senado ${ }^{340}$.

Nos entes subnacionais, à semelhança do que ocorre na esfera federal, as constituições estaduais e as leis orgânicas municipais preveem a atuação de comissões de parlamentares na accountability financeira e orçamentária da Administração Pública do respectivo ente, e as casas legislativas criam comissōes temáticas para fazer frente a tais atividades.

Por exemplo, a Constituição do Estado de São Paulo de $1989^{341}$, em seus artigos 33, incisos V e VIII, e 34, prevê a atuação de comissões técnicas na fiscalização financeira e orçamentária da Administração Pública estadual. Para fazer frente a tal atividade, a Assembleia Legislativa do Estado, conforme seu regimento interno ${ }^{342}$, artigo 30, incisos II e XV, combinado com o artigo 31, parágrafos $2^{\circ}$ e 15 , criou duas comissōes permanentes, quais sejam, a Comissão de Finanças, Orçamento e Planejamento e a Comissão de Fiscalização e Controle.

Do mesmo modo, na Lei Orgânica do município de São Paulo ${ }^{343}$ há previsão, em seus artigos 48, incisos IV, alínea "a", e VII, e 52, da atuação de comissões técnicas na fiscalização financeira e orçamentária da Administração Pública municipal. Assim, a Câmara Municipal de São Paulo, de acordo com seu regimento interno ${ }^{344}$, artigo 39, inciso II, combinado com o artigo 47, inciso II, mantém a Comissão de Finanças e Orçamentos.

339 BRASIL. Câmara dos Deputados. Regimento interno da Câmara dos Deputados: aprovado pela Resolução n. 17, de 1989, e alterado até a Resolução n. 6, de 2019. Brasília: Câmara dos Deputados, 2019. Disponível em: https://www2.camara.leg.br/atividade-legislativa/legislacao/regimento-interno-da-camara-dos-deputados. Acesso em: 23 out. 2019. p. 27-28.

340 BRASIL. Senado Federal. Resolução n. 93, de 1970. Dá nova redação ao Regimento Interno do Senado Federal. Brasília: Senado Federal, 2019. Disponível em: http://www25.senado.leg.br/web/atividade/ regimento-interno\#/. Acesso em: 23 out. 2019. p. 31-34.

341 SÃO PAULO (Estado). Constituição (1989). Constituição do Estado de São Paulo. Atualizada até a Emenda Constitucional n. 47, de 14 de março de 2019. Disponível em: https://www.al.sp.gov.br/repositorio/legislacao/constituicao/1989/compilacao-constituicao-0-05.10.1989.html. Acesso em: 19 mar. 2019.

342 SÃO PAULO (Estado). Assembleia Legislativa do Estado. Resolução n. 576, de 26 de junho de 1970. Adapta o Regimento Interno às normas constitucionais. Atualizada até a Resolução n. 918, de 14 de dezembro de 2018. Disponível em: https://www.al.sp.gov.br/repositorio/legislacao/resolucao. alesp/1970/compilacao-resolucao.alesp-576-26.06.1970.html. Acesso em: 19 mar. 2019.

343 SÃO PAULO (Município). Lei Orgânica (1990). Lei Orgânica do Município de São Paulo. Atualizada até a Emenda n. 40, de 2017. São Paulo: Câmara Municipal de São Paulo, 2018. Disponível em: http:// www.saopaulo.sp.leg.br/wp-content/uploads/2018/01/LOMC.pdf. Acesso em: 11 mar. 2019. p. 23-25.

344 SÃO PAULO (Município). Câmara Municipal. Resolução n. 2, de 26 de abril de 1991. Dispões sobre o Regimento Interno da Câmara Municipal de São Paulo. Atualizada até a Resolução n. 10, de 2 de abril 
A previsão na CRFB/1988, nas constituiçôes estaduais e leis orgânicas municipais e distrital de comissões específicas encarregadas de operacionalizar, no âmbito do Poder Legislativo, a accountability financeira e orçamentária da Administração Pública é salutar. Nesse sentido, Odete Medauar assevera que "A especialização da função de controle em câmara ou em comissões parece levar ao aprimoramento da função de controle" 345 .

Contudo, como ela destaca ${ }^{346}$, considerando o volume, a complexidade e o tecnicismo das atividades exercidas pela Administração Pública atualmente, o exercício de um controle externo sistemático e eficiente vai além das possibilidades de trabalho dos parlamentares, seja porque não estão dotados da competência técnica necessária, seja porque estão absorvidos por suas atividades legislativa e política.

Aliomar Baleeiro dizia ser evidente que, em razão do desdobramento das funções governamentais, não há casa legislativa “[...] que possa fiscalizar cada uma das parcelas da despesa e apurar se o dinheiro foi gasto para o fim estritamente alegado e autorizado ou se o Executivo o desviou para fim diverso" ${ }^{347}$. Diante disso, segundo ele, "Surgiu a necessidade de um órgão para controlar a execução do orçamento de sorte que o Legislativo não seja ludibriado pelo Executivo"348. Nesse sentido, como destaca Marcos Valério de Araújo, não dispondo o Poder Legislativo de condições para efetivamente realizar a análise técnica das despesas e a fiscalização dos atos de gestão, "Torna-se fundamental a existência de um órgão especializado e independente que, por delegação de competência da Sociedade e [...] do próprio Poder Legislativo, realize o controle técnico e legal da gestão financeira governamental"349.

Tal solução, segundo Alfredo Buzaid, foi acolhida pelo direito. Tanto que, ao tratar da impossibilidade de o Legislativo exercer isoladamente a fiscalização financeira e orçamentária da Administração, asseverou que "[...] o direito moderno dos povos civilizados houve por bem confiá-la a uma corporação distinta, chamada Tribunal de

de 2013. São Paulo: Câmara Municipal de São Paulo, 2014. Disponível em: http://www.camara.sp.gov. br/wp-content/uploads/2014/10/regimento-interno-2013-RC291C.pdf. Acesso em: 18 abr. 2017. p. $16 ; 19$.

345 MEDAUAR, Odete. Controle parlamentar da administração. Revista de Informação Legislativa, Brasília, v. 27, n. 107, p. 111-130, jul./set. 1990. p. 130.

346 MEDAUAR, Odete. Controle parlamentar da administração. Revista de Informação Legislativa, Brasília, v. 27, n. 107, p. 111-130, jul./set. 1990. p. 114; e MEDAUAR, Odete. Controle da administração pública pelo tribunal de contas. Revista de Informação Legislativa, Brasília, v. 27, n. 108, p. 101126, out./dez. 1990. p. 102.

347 BALEEIRO, Aliomar. O tribunal de contas e o controle da execução orçamentária. Revista de Direito Administrativo, Rio de Janeiro, v. 31, p. 10-22, 1953. p. 12.

348 BALEEIRO, Aliomar. O tribunal de contas e o controle da execução orçamentária. Revista de Direito Administrativo, Rio de Janeiro, v. 31, p. 10-22, 1953. p. 12.

349 ARAÚJO, Marcos Valério de. Como controlar o Estado: reflexôes e propostas sobre o controle externo nas Américas, Portugal e Espanha. Brasília: UNITEC, 1992. p. 16. 


\section{-• Contas dos governantes}

Contas, para que a sua atividade, exercida de modo permanente, ficasse a salvo das agitações políticas" 350 .

Pelo exposto, a par de legislar, o parlamento foi comissionado pelos cidadãos para exercer o controle externo da gestão financeira e orçamentária da Administração Pública, como agente de accountability horizontal. Porém, em razão do volume, da complexidade e do tecnicismo das atividades exercidas pela Administração atualmente, bem como do esforço exigido pelas atividades legislativa e política, o exercício de um controle externo sistemático e eficiente vai além das possibilidades de trabalho dos parlamentares.

Por outro lado, a adoção do instituto da representação nas democracias representativas contemporâneas exige, em contrapartida, a instituição de um sistema efetivo de accountability, inclusive em relação à gestão financeira e orçamentária. Desse modo, na seção seguinte deste trabalho, trata-se da solução encontrada pelo sistema jurídico para reforçar a accountability financeira e orçamentária da Administração Pública.

\subsection{CONTROLE EXTERNO PELOS TRIBUNAIS DE CONTAS}

Diante da incapacidade - para Charles Pessanha ${ }^{351}$, verdadeira ineficácia - do parlamento, como exposto na seção anterior, para realizar, isoladamente, um controle externo sistemático e eficiente, a solução encontrada pelo sistema jurídico para reforçar a accountability financeira e orçamentária da Administração Pública, foi a criação de órgãos especializados com essa finalidade. Tal solução é consagrada mundo afora. Tão difundida que a INTOSAI congrega atualmente cento e noventa e quatro agências governamentais qualificadas como supreme audit institutions ou instituiçôes superiores de controle (ISC) $)^{352}$, também conhecidas como entidades fiscalizadoras superiores, EFS ou SAI.

Em sua composição, as ISC variam entre aquelas estruturadas como uma agência unipessoal e aqueloutras formadas como um órgão colegiado. As agências unipessoais

350 BUZAID, Alfredo. O tribunal de contas no Brasil. Revista da Faculdade de Direito da Universidade de São Paulo, São Paulo, v. 62, n. 2, p. 37-62, 1967. p. 38-39.

351 PESSANHA, Charles. Controle externo: a função esquecida do legislativo no Brasil. In: SCHWARTZMAN, Luisa Farah; SCHWARTZMAN, Isabel Farah; SCHWARTZMAN, Felipe Farah; SCHWARTZMAN, Michel Lent (Org.). O sociólogo e as políticas públicas. Rio de Janeiro: Fundação Getúlio Vargas, 2009. p. 246.

352 A INTOSAI possui centro e noventa e duas ISC de países e a ISC da União Europeia, como membras plenas, além da ISC de Guam, que é membra afiliada, cf. INTERNATIONAL ORGANIZATION OF SUPREME AUDIT INSTITUTIONS (INTOSAI). INTOSAI Members [website]. Disponível em: https://www.intosai.org/about-us/members. Acesso em: 23 out. 2019. Para efeito de comparação, a Organização das Naçôes Unidas e a Fédération Internationale de Football Association possuem hoje, respectivamente, cento e noventa e três e duzentos e onze países membros, cf. UNITED NATIONS. Member States [website]. Disponível em: https://www.un.org/en/member-states/. Acesso em: 23 out. 2019; e FÉDÉRATION INTERNATIONALE DE FOOTBALL ASSOCIATION. Associations and confederations [website]. Disponível em: https://www.fifa.com/associations/. Acesso em: 23 out. 2019. 
geralmente são denominadas de controladoria ou escritório - office - do auditor ou controlador e, como ensina Marianna Montebello Willeman ${ }^{353}$, têm como referência o modelo de Westminster. Por outro lado, segundo ela, as agências colegiadas podem ter como referência o modelo napoleônico, dos conhecidos tribunais ou cortes de contas, ou o audit board system, que é uma variação colegiada do modelo de Westminster.

É necessário destacar que os modelos, indicados no parágrafo anterior, são apenas referências, pois, na realidade, os arranjos institucionais das ISC variam de um país para outro, ainda que tenham como referência o mesmo modelo. Por exemplo, comumente, entende-se, com Francisco Eduardo Carrilho Chaves ${ }^{354}$, que as agências unipessoais, ao contrário dos tribunais de contas, não detêm competências para aplicar sançōes ou cobrar ressarcimentos dos agentes públicos. Todavia, como demonstra Marcos Valério de Araújo ${ }^{355}$, (i) existem tribunais de contas que fiscalizam, aplicam sançôes e exigem ressarcimentos; (ii) existem tribunais de contas que apenas fiscalizam, sem competência para aplicação de sançôes ou cobrança de ressarcimentos; (iii) existem controladorias que apenas fiscalizam; e (iv) existem controladorias que fiscalizam e acumulam competência para aplicar sanções e exigir ressarcimentos.

No Brasil ${ }^{356}$, ao se instituir a agência de accountability horizontal especializada que exerceria o papel de ISC, optou-se por um órgão colegiado, tendo o modelo napo-

353 WILLEMAN, Marianna Montebello. A accountability democrática e o desenho institucional dos tribunais de contas no Brasil. 2. ed. Belo Horizonte: Fórum, 2020. p. 108-109.

354 CHAVES, Francisco Eduardo Carrilho. Controle externo da gestão pública: a fiscalização pelo Legislativo e pelos tribunais de contas. Niterói: Impetus, 2007. p. 11.

355 ARAÚJO, Marcos Valério de. Como controlar o Estado: reflexões e propostas sobre o controle externo nas Américas, Portugal e Espanha. Brasília: UNITEC, 1992. p. 18-19.

356 Para análises comparativas a respeito da organização institucional e das competências das ISC de diversos países, para o exercício do controle externo, cf. NORMANTON, E. L. The accountability and audit of governments: a comparative study. Manchester: Manchester University Press, 1966. p. 28-57; MEDAUAR, Odete. Controle da administração pública pelo tribunal de contas. Revista de Informação Legislativa, Brasília, v. 27, n. 108, p. 101-126, out./dez. 1990. p. 104-113; ARAÚJO, Marcos Valério de. Como controlar o Estado: reflexões e propostas sobre o controle externo nas Américas, Portugal e Espanha. Brasília: UNITEC, 1992; BAC, Aad. International comparative issues on government accounting: the similarities and differences between central government accountability and local government accounting within or between countries. Dordrecht: Kluwer Academic Publishers, 2001; LAFFAN, Brigid. Auditing and accountability in the European Union. Journal of European Public Policy, London, v. 10, n. 5, p. 762-777, oct. 2003. DOI: 10.1080/1350176032000124078; UNITED KINGDOM. National Audit Office (NAO). State audit in the European Union. 3. ed. London: NAO, 2005; HARDEN, Ian; WHITE, Fidelma; DONNELLP, Katy. The Court of Auditors and financial control and accountability in the European Community, European Public Law, Hull, v. 1, n. 4, p. 599-632, 2009; FIGUEIREDO, Carlos Mauricio Cabral. Results of capacity development in a Supreme Audit Institution: the case of Mozambique. In: INTERNATIONAL ORGANIZATION OF SUPREME AUDIT INSTITUTIONS (INTOSAI). Supreme Audit Institutions: accountability for development. Baden-Baden: Nomos Verlagsgesellschaft, 2013. p. 273-281; CHOUVEL, Rudy. External financial auditing of local and regional governments by Regional Audit Institutions in the European Union. Croatian and comparative public administration, Zagreb, v. 17, n. 1, p. 57-80, mar. 2017. DOI: 10.31297/hkju.17.1.4; BRENNINKMEIJER, Alex; GELDER, Emma Van. The European 


\section{•- Contas dos governantes}

leônico como referência, como fica claro na leitura conjunta dos artigos 71, 73 e 75 da CRFB/1988.

Assim, na esfera federal, enquanto pelo artigo 71 da CRFB/1988 verifica-se que o órgão que auxilia o Poder Legislativo no exercício do controle externo é o TCU, pelo seu artigo 73 verifica-se que ele é colegiado, composto por nove ministros ${ }^{357}$. Para a União $^{358}$, desde a primeira constituição republicana, como se pode observar no artigo 89 da Constituição da República dos Estados Unidos do Brasil de 1891, os constituintes fizeram clara opção por um tribunal de contas.

Por outro lado, a CRFB/1988, por força de seu artigo 75, foi a primeira a definir esse modelo de agência de accountability financeira e orçamentária como obrigatório para estados, DF e municípios. Até então, como destacou em mais de uma oportunidade Aliomar Baleeiro ${ }^{359}$, os constituintes estaduais eram livres para adotar o modelo que, a seu juízo, melhor atendesse às necessidades locais, considerando a escala das Administrações Públicas subnacionais. Nesse sentido, na vigência da Constituição dos Estados Unidos do Brasil de 1946, Alfredo Buzaid afirmou que

A Constituição Federal é, por larga tradição, um modelo a que se compõem as constituições estaduais. Mas, no que respeita à fiscalização das finanças públicas, têm os Estados a liberdade de criar o órgão que há de exercê-la. A Constituição Federal poderia ter disposto diferentemente, nomeando desde logo a corporação e fixando-lhe as atribuições. Mas, querendo ser fiel ao sistema federativo, que corresponde à tradição republicana, julgou técnica e juridicamente mais acertado reservar aos Estados tal competência, respeitando-lhes assim a autonomia ${ }^{360}$.

Court of Auditors: the guardian of EU finances. In: SHOLTEN, Miroslava; LUCHTMAN, Michiel. Law enforcement by EU authorities: implications for political and judicial accountability. Cheltenham: Edward Elgar Publishing Limited, 2017. p. 305-329; CHADID, Ronaldo. A função social do Tribunal de Contas no Brasil. Belo Horizonte: Fórum, 2019. p. 142-162; RODRIGUEZ GARCIA, Armando. Bases conceptuales del control de cuentas de la administracion y sus posibles distorsiones. Referencias al caso venezolano. In: RODRÍGUEZ-ARANA, Jaime; DELPIAZZO, Carlos; SILVA FILHO, João Antonio da; VALIM, Rafael; RODRÍGUEZ, María. Control administrativo de la actividad de la administración. v. 1. São Paulo: 2019. (XVIII Foro Iberoamericano de Derecho Administrativo). p. 244-248; e WILLEMAN, Marianna Montebello. A accountability democrática e o desenho institucional dos tribunais de contas no Brasil. 2. ed. Belo Horizonte: Fórum, 2020. p. 117-134.

357 A respeito da composição dos tribunais de contas e dos atributos constitucionais para a escolha de seus membros, cf. WILLEMAN, Marianna Montebello. A accountability democrática e o desenho institucional dos tribunais de contas no Brasil. 2. ed. Belo Horizonte: Fórum, 2020. p. 213-237.

358 A respeito da criação do Tribunal de Contas da União, cf. CAVALCANTI, Themístocles Brandão. O tribunal de contas - órgão constitucional - funções próprias e funçôes delegadas. Revista de Direito Administrativo, Rio de Janeiro, v. 109, p. 1-10, 1972. p. 2-5.

359 Cf. SÁ FILHO; BALEEIRO, Aliomar; VIANA, Arízio de; CANTO, Gilberto de Ulhôa; ALMIRO, Affonso. Normas gerais de direito financeiro. Rio de Janeiro: Ediçōes Financeiras, 1950. p. 20; e BALEEIRO, Aliomar. O tribunal de contas e o controle da execução orçamentária. Revista de Direito Administrativo, Rio de Janeiro, v. 31, p. 10-22, 1953. p. 21-22.

360 BUZAID, Alfredo. O tribunal de contas no Brasil. Revista da Faculdade de Direito da Universidade de São Paulo, São Paulo, v. 62, n. 2, p. 37-62, 1967. p. 46. 
Isto posto, poderiam, por exemplo, optar por uma agência unipessoal, instituindo controladorias para colaborar com o Poder Legislativo no exercício do controle externo. Não obstante, na prática, antes mesmo da promulgação da atual constituição, todos os estados brasileiros - salvo os que ainda eram territórios federais, não gozando do status de estado federado - já haviam adotado o modelo colegiado, com a criação de tribunais de contas próprios ${ }^{361}$.

Como resultado da opção constitucional, existem hoje no Brasil trinta e três tribunais de $\operatorname{contas}^{362}$. Entre eles o TCU, o TC-DF, vinte e seis tribunais de contas de estado - um para cada estado da federação -, três tribunais de contas dos municípios - órgãos estaduais com competência sobre as contas dos municípios - e dois tribunais de contas de município - no Rio de Janeiro e em São Paulo.

Embora tenha permitido a manutenção dos tribunais de contas municipais então existentes - o TCM-SPO e o TCM-RIO foram criados, respectivamente, em 1968 e $1980^{363}$-, a CRFB/1988, no $\$ 4^{\circ}$ de seu artigo 31, vedou “[...] a criação de Tribunais, Conselhos ou órgãos de Contas Municipais" 364 . Tal vedação, para Tatiana Penharrubia Fagundes, seria uma "injustiça constitucional”, na medida em que sua criação no âmbito municipal, segundo ela, "[...] reforçaria a autonomia dos Municípios” ${ }^{65}$. Nisso ela ecoa Manoel Ribeiro, segundo quem "Somente será possível a harmonia se a fiscalização for efetuada por algum órgão municipal. Não, porém, qualquer órgão, mas um que se coloque como freio entre o legislativo e o executivo [...]"366.

361 A respeito da cronologia de formação dos tribunais de contas do Brasil, cf. SIMÔES, Edson. Tribunais de contas: controle externo das contas públicas. São Paulo: Saraiva, 2014. p. 385-474.

362 Até 16 de agosto de 2017, quando o Tribunal de Contas dos Municípios do Estado do Ceará (TCM-CE) foi extinto por meio de Emenda à Constituição do Estado do Ceará, existiam no Brasil trinta e quatro tribunais de contas. A respeito da possibilidade de extinção de tribunais de contas dos municípios de determinado estado, pela respectiva assembleia legislativa, cf. MOUTINHO, Donato Volkers. Assembleia legislativa pode extinguir tribunal de contas dos municípios. Revista Consultor Jurídico, São Paulo, 31 ago. 2017. Disponível em: https://www.conjur.com.br/2017-ago-31/donato-volkers-assembleia-legislativa-extinguir-tcm. Acesso em: 11 jun. 2019; e HOLANDA, Daniele Ferreira de Almeida Vieira. Uma análise da extinção dos tribunais de contas dos municípios à luz da Constituição Federal. Revista Controle, Fortaleza, v. 16, n. 1, p. 362-393, jan./jun. 2018. DOI: https://doi.org/10.32586/ rcda.v16i1.400.

363 Cf. SÃO PAULO (Município). Tribunal de Contas do Município. Jubileu de ouro: 50 anos de história. São Paulo: Tribunal de Contas do Município de São Paulo, 2018. Disponível em: https://portal.tcm. sp.gov.br/Management/GestaoPublicacao/DocumentoId?idFile=094d04b7-da0d-48d8-98ea-9aae4b1c17e9. Acesso em: 23 out. 2019. p. 12; e RIO DE JANEIRO (Município). Tribunal de Contas do Município. Sobre o TCMRJ [website]. Disponível em: http://www.tcm.ri.gov.br/WEB/Site/Destaques.aspx?group=SobreTCMRJ. Acesso em: 23 out. 2019.

364 BRASIL. Constituiçãoo (1988). Constituição da República Federativa do Brasil. Disponível em: http:// www.planalto.gov.br/ccivil_03/Constituicao/Constituicao.htm. Acesso em: 2 dez. 2019.

365 FAGUNDES, Tatiana Penharrubia. O controle das contas municipais. 2012. 273 f. Tese (Doutorado em Direito) - Departamento de Direito do Estado, Faculdade de Direito, Universidade de São Paulo, São Paulo, 2012. p. 243.

366 RIBEIRO, Manoel. O município na federação. Salvador: Universidade da Bahia, 1959. p. 90-91. 


\section{•. Contas dos governantes}

Tal vedação, vale dizer, é para a criação de cortes de contas na estrutura organizacional própria dos municípios, não para a instituição de tribunais de contas dos municípios de determinado estado. Desse modo, a CRFB/1988 não veda a criação de novos tribunais de contas estaduais especializados no controle externo dos municípios, a exemplo dos atuais TCM da Bahia, de Goiás e do Pará ${ }^{367}$. Não obstante, os três tribunais de contas dos municípios de estado existentes atualmente já existiam no regime constitucional anterior, de forma que nenhum estado instalou ${ }^{368}$ órgão com esse propósito específico após a promulgação da Constituição de 1988.

Ao contrário, alguns estados, optando pela reunião das competências de controle externo da gestão financeira e orçamentária das Administrações Públicas estadual e municipais num único órgão, decidiram extinguir os tribunais de contas dos municípios que mantinham. Assim, foram extintos, por exemplo, os TCM do Maranhão, em 1993, do Amazonas, em 1995, e do Ceará, em 201769.

Em relação à estrutura do sistema constitucional de accountability financeira e orçamentária, deve-se ter em mente, como destaca Jorge Ulisses Jacoby Fernandes, que diversamente da estrutura do Poder Judiciário, desenhada pela CRFB/1988, "Não há recurso de Tribunal de Contas de Município para Tribunal de Contas de Estado, nem deste para o da União, atuando, cada tribunal, em sua esfera da federação, como instância máxima"370.

367 Até a CRFB/1988 era comum denominar as cortes estaduais de controle externo dos municípios de "Conselho de Contas dos Municípios". Por exemplo, eram chamados dessa forma os atuais TCM-GO e TCM-PA e os extintos tribunais de contas dos municípios dos estados do Ceará e do Maranhão.

368 Peculiar é a situação do Tribunal de Contas dos Municípios do Estado da Paraíba: criado formalmente pela Emenda à Constituiçãao n. 5 , de 24 de novembro de 1994, e previsto no texto da constituição estadual desde então, ele nunca chegou a ser instalado. Em 5 de março de 2008, o Partido dos Trabalhadores ajuizou ação direta de inconstitucionalidade em face da referida emenda constitucional. Finalmente, em 28 de janeiro de 2015, a ação foi julgada procedente e a Emenda à Constituição da Paraíba n. 5/1994 foi declarada inconstitucional por não ter sido precedida de estudo de adequação orçamentária e financeira, cf. PARAÍBA. Tribunal de Justiça do Estado. Ação direta de inconstitucionalidade 079764697.2008.815.0000. Relator: Desembargador Leandro dos Santos. Tribunal Pleno, João Pessoa, 28 de janeiro de 2015. Diário da Justiça Eletrônico [do] Estado da Paraíba, João Pessoa, n. 14.747, p. 13, 2 fev. 2015. Disponível em: http://tjpb-jurisprudencia-dje.tjpb.jus.br/dje/2015/1/30/8370a661-720146c2-911e-8f71bb70fe6c.pdf. Acesso em: 27 nov. 2017.

369 Cf. MARANHÃO. Emenda à Constituição n. 9, de 25 de março de 1993. Extingue o Tribunal de Contas dos Municípios e dá outras providências. Diário Oficial [do] Estado do Maranhão, São Luís, 30 mar. 1993. Disponível em: http://www.stc.ma.gov.br/legisla-documento/?id=2191. Acesso em: 27 nov. 2017; AMAZONAS. Emenda à Constituição n. 15, de 16 de março de 1995. Altera a redação dos dispositivos, que indica, da Constituição do Estado do Amazonas. Diário Oficial [do] Estado do Amazonas, Manaus, n. 28.156, Poder Legislativo, p. 1, 21 mar. 1995. Disponível em: http://diario.imprensaoficial. am.gov.br/diariooficial/consultaPublica.do. Acesso em: 27 nov. 2017; e CEARÁ. Emenda Constitucional n. 92, de 16 de agosto de 2017. Extingue o Tribunal de Contas dos Municípios do Estado do Ceará. Diário Oficial do Estado [do] Ceará, Fortaleza, n. 157, p. 105-106, 21 ago. 2017. Disponível em: http:// imagens.seplag.ce.gov.br/PDF/20170821/do20170821p02.pdf\#page=105. Acesso em: 27 nov. 2017.

370 FERNANDES, Jorge Ulisses Jacoby. Tribunais de contas do Brasil: jurisdição e competência. 4. ed. Belo Horizonte: Fórum, 2016. p. 640. 
É claro que contra suas decisões cabem recursos, e nem poderia ser diferente em respeito ao devido processo legal, todavia eles são interpostos e julgados no próprio âmbito do tribunal de contas prolator da decisão recorrida ${ }^{371}$. Isso ocorre porque, como explica Luiz Henrique Lima ${ }^{372}$, a competência de cada corte de controle externo é delimitada em função da origem dos recursos públicos empregados.

Deve ficar claro que, ao se afirmar que, no âmbito da accountability financeira e orçamentária da Administração Pública, o Brasil adotou o modelo napoleônico dos tribunais de contas, não se quer dizer que suas agências especializadas de accountability horizontal são iguais àquelas dos países que fizeram semelhante opção. Embora a doutrina aponte alguns tribunais de contas como paradigmas para a criação do $\mathrm{TCU}^{373}$, há diferenças relevantes entre os atuais tribunais de contas brasileiros e quaisquer desses, especialmente na sua relação com o parlamento, em sua posição na estrutura do Estado e quanto à possibilidade e a forma de revisão de suas decisōes por outros órgãos, nas características dos processos que se desenvolvem em seu âmbito e quanto às fontes de normas que regulam sua atividade. Essas questóes são abordadas nas subseções seguintes.

\subsubsection{Relação entre os tribunais de contas e os parlamentos}

Diante do exposto até aqui neste trabalho, para tratar da relação entre os tribunais de contas e as casas legislativas em cada unidade federativa, deve-se ter em mente alguns pontos. Conforme o capítulo 1 (p. 39), sabe-se que a accountability é essencial no contexto das democracias representativas contemporâneas e que a accountability vertical é insuficiente para induzir que os representantes ajam no melhor interesse dos representados, tornando necessária a prestação de contas a outros órgãos públicos.

Esse papel de sujeito ativo da accountability horizontal, como apresenta a seção 2.4 (p. 97), cabe, naturalmente, ao parlamento. Porém, diante de sua incapacidade para exercer com eficácia tal função, especificamente em relação à gestão financeira e

371 A respeito do funcionamento do sistema recursal nos tribunais de contas, cf. MOUTINHO, Donato Volkers. Primeiras linhas de uma teoria geral dos recursos nos tribunais de contas. 2011. $295 \mathrm{f}$. Monografia (Graduação em Direito) - Departamento de Direito, Centro de Ciências Jurídicas e Econômicas, Universidade Federal do Estado do Espírito Santo, Vitória, 2011.

372 LIMA, Luiz Henrique. Anotações sobre a singularidade do processo de controle externo nos tribunais de contas: similaridades e distinções com o processo civil e penal. In: LIMA, Luiz Henrique; SARQUIS, Alexandre Manir Figueiredo (Coord.). Processos de controle externo: estudos de ministros e conselheiros substitutos dos tribunais de contas. Belo Horizonte: Fórum, 2019. p. 31.

373 A respeito dos três tribunais de contas apontados, pela doutrina, como paradigmas para a criação do TCU, quais sejam, o italiano, o francês e o belga, cf. BUZAID, Alfredo. O tribunal de contas no Brasil. Revista da Faculdade de Direito da Universidade de São Paulo, São Paulo, v. 62, n. 2, p. 37-62, 1967. p. 43-44; e FAGUNDES, Tatiana Penharrubia. O controle das contas municipais. 2012. 273 f. Tese (Doutorado em Direito) - Departamento de Direito do Estado, Faculdade de Direito, Universidade de São Paulo, São Paulo, 2012. p. 84-93. 


\section{-• Contas dos governantes}

orçamentária da Administração Pública, surgiu a necessidade da criação das ISC, de acordo com a seção 2.5 (p. 104). Por essa razão, foram criados os tribunais de contas no Brasil.

Como desempenham uma função umbilicalmente ligada aos parlamentos, seu desenho institucional, na atual constituição brasileira ${ }^{374}$, está numa seção - fiscalização financeira e orçamentária - topograficamente localizada dentro do capítulo que trata do Poder Legislativo. Tendo isso em conta e que, no caput do artigo $71 \mathrm{da}$ CRFB/1988, está expresso que devem auxiliar o Congresso Nacional, alguns autores defendem que ele não somente integra aquele Poder, como lhe é subordinado.

Assim, Aliomar Baleeiro ${ }^{375}$, ao tempo em que vigia a Constituição de 1946, dizia bastar para filiar o TCU ao Congresso Nacional o fato de ele estar incluído numa seção constitucional dentro do capítulo que tratava do Poder Legislativo. No mesmo sentido, Alfredo Buzaid ${ }^{376}$, citando o cuidado que o legislador constituinte de 1946 teve com a sistematização das matérias, ancorava-se no mesmo fundamento para incluir os tribunais de contas como órgãos do Legislativo. Sob idêntico texto constitucional, Manoel Ribeiro ${ }^{377}$ somava-se aos que defendiam a sua natureza de auxiliar do Legislativo.

Sob a CRFB/1988, invocando igual argumento, Felipe Braga Albuquerque afirma que "[...] basta analisar a Constituição sistematicamente para constatar que [...], na verdade, o Tribunal de Contas é órgão do Poder Legislativo” ${ }^{378}$. A LRF contribui para esse entendimento, na medida em que as cortes de controle externo são contadas como órgãos do Poder Legislativo no artigo $1^{\circ}, \$ 3^{\circ}$, inciso I, alínea "a", e no artigo 20, $\$ 2$, inciso II, alíneas “a”, “b” e “c”.

Por outro lado, José de Castro Nunes, sob a Constituição de 1937, reconhecendo que as cortes de contas “[...] existem em função da atribuição política dos parlamentos no exame das contas de cada exercício financeiro" ${ }^{379}$, defendia sua autonomia e inde-

374 A respeito do relacionamento entre as ISC e os parlamentos, na Alemanha, na Austrália, na Espanha, nos Estados Unidos da América, na França, na Itália e no Reino Unido, cf. COSTA, Paulo Nogueira da. O tribunal de contas e a boa governança. 2. ed. Lisboa: Petrony Editora, 2017. p. 81-90.

375 BALEEIRO, Aliomar. O tribunal de contas e o controle da execução orçamentária. Revista de Direito Administrativo, Rio de Janeiro, v. 31, p. 10-22, 1953. p. 11.

376 BUZAID, Alfredo. O tribunal de contas no Brasil. Revista da Faculdade de Direito da Universidade de São Paulo, São Paulo, v. 62, n. 2, p. 37-62, 1967. p. 61.

377 RIBEIRO, Manoel. O município na federação. Salvador: Universidade da Bahia, 1959. p. 89.

378 ALBUQUERQUE, Felipe Braga. Lei de responsabilidade fiscal e o Poder Legislativo: uma análise do papel dos tribunais de contas. In: CONGRESSO NACIONAL DO CONSELHO NACIONAL DE PESQUISA E PÓS-GRADUAÇÃO EM DIREITO (CONPEDI), 14., 2005, Fortaleza. Anais eletrônicos... Fortaleza: CONPEDI, 2005. Disponível em: http://www.publicadireito.com.br/conpedi/ anais.php. Acesso em: 21 abr. 2017.

379 NUNES, José de Castro. Teoria e prática do Poder Judiciário. Rio de Janeiro: Revista Forense, 1943. p. 26. 
pendência. Themístocles Brandão Cavalcanti, na vigência da Constituição de 1967, defendia que, a par de exercerem funções delegadas pelo Congresso, os tribunais de contas exerciam funções próprias, decorrentes de sua competência constitucional ${ }^{380}$.

Essa suposta delegação requer alguns comentários a respeito. Embora originariamente o controle externo da gestão financeira e orçamentária do Estado coubesse aos parlamentares, como legítimos representantes do povo, pelas razões apresentadas na seções 2.4 (p. 97) e 2.5 (p. 104) deste trabalho, parte de suas funções foram transferidas aos tribunais de contas como agentes especializados de accountability horizontal. Por outro lado, parcela de suas funções foi mantida.

Ocorre que essa transferência de funções não foi realizada ordinariamente, como uma simples delegação, que possa ser revogada a qualquer instante. Antes, foi realizada por um parlamento formado por representantes extraordinários da população, reunidos em Assembleia Nacional Constituinte, e dotados, por delegação do próprio povo, daquilo que Emmanuel Joseph Sieyès ${ }^{381}$ denominou poder constituinte.

Portanto, as cortes de contas exercem suas atividades de controle externo, ao lado do Poder Legislativo, não por delegação deste, mas por atribuição do poder constituinte.

Nesse sentido, o STF decidiu que o tribunal de contas não é preposto - aquele que realiza uma atividade por delegação - do Poder Legislativo, declarando "[...] inconstitucional a expressão 'órgão preposto do legislativo', inserida no art. $2^{\circ}$ da Lei n. 3.564, de 08 de junho de 1983, do Estado do Espirito Santo"382. Outrossim, Vitor Rolf Laubé, diferentemente de Aliomar Baleeiro, Alfredo Buzaid e Felipe Braga Albuquerque, afirma que "[...] apesar da Corte de Contas estar contida no capítulo da Carta Magna que trata do Legislativo, tal fato não é suficiente para se poder afirmar que o citado órgão esteja inserido na estrutura desse 'poder"'383, além de destacar que os tribunais de contas não foram previstos como componentes do Congresso Nacional no caput do artigo 44 da CRFB/1988.

$\mathrm{Na}$ verdade, as cortes de controle externo foram acertadamente, pois essa é a sua razão de existir, previstas na seção constitucional que trata da fiscalização financeira e orçamentária da Administração Pública. Por outro lado, tal seção foi incluída dentro do capítulo do Poder Legislativo porque o controle externo da gestão financeira e orçamentária é uma de suas mais importantes funções.

380 CAVALCANTI, Themístocles Brandão. O tribunal de contas - órgão constitucional - funções próprias e funçōes delegadas. Revista de Direito Administrativo, Rio de Janeiro, v. 109, p. 1-10, 1972. p. 6-7.

381 SIEYĖS, Emmanuel Joseph. Qu'est-Ce Que Le Tiers État? Paris: Éditions du Boucher, 2002. p. 53.

382 BRASIL. Supremo Tribunal Federal. Representação n. 1.179-8 Espírito Santo. Relator: Ministro Alfredo Buzaid. Tribunal Pleno, Brasília, 29 de junho de 1984. Revista de Direito Administrativo, Rio de Janeiro, v. 158, p. 196-202, 1984. p. 202.

383 LAUBÉ, Vitor Rolf. Consideraçôes acerca da conformação constitucional do tribunal de contas. Revista de Informaçáo Legislativa, Brasília, v. 29, n. 113, p. 307-326, jan./mar. 1992. p. 321. 


\section{-• Contas dos governantes}

Isso não quer dizer, em absoluto, que os tribunais de contas fazem parte do Poder Legislativo, do mesmo modo que as unidades que exercem o controle interno da Administração Pública, previsto na mesma seção constitucional, não estão subordinadas ao parlamento, com exceção daquelas unidades responsáveis pelo controle interno do próprio Legislativo. Por isso, Carlos Ayres Britto afirma que "[...] o Tribunal de Contas da União não é órgão do Congresso Nacional, não é órgão do Poder Legislativo" 384 .

Jarbas Maranhão entendia “[...] que a palavra 'auxílio’ deve ser entendida como colaboração funcional e não subordinação hierárquica ou administrativa” ${ }^{385}$. Como assevera Carlos Ayres Britto, “[...] nenhum Tribunal de Contas opera no campo da subalterna auxiliaridade" ${ }^{386}$. Nesse sentido, ressaltando a confusão causada pelo termo "auxílio" utilizado no caput do artigo 71 da CRFB/1988, mas considerando o conjunto das normas constitucionais, Odete Medauar assevera que a corte de contas é "[...] órgão independente, desvinculado da estrutura de qualquer dos três Poderes” ${ }^{387}$.

Fossem os tribunais de contas órgãos subordinados aos parlamentos, solapado estaria, por exemplo, o controle externo da gestão financeira e orçamentária do próprio Poder Legislativo, responsabilidade dos tribunais de contas, como mostra a subseção 3.3.3 (p. 281). Por isso é que Eduardo Lobo Botelho Gualazzi afirma que o "[...] órgão necessita sempre de eqüidistância, no tocante aos três Poderes, inclusive ao Legislativo, a fim de que sua atividade de controle não se subordine, juridicamente, a Poder algum do Estado [...]"388.

Segundo José Mauricio Conti, há outro ingrediente que reforça a independência e a autonomia das cortes de controle externo, qual seja, a decisão do constituinte de outorgar aos seus membros as mesmas garantias, prerrogativas, impedimentos, vencimentos e vantagens de membros do Poder Judiciário. Segundo ele, "Não teria sentido estabelecerem-se estas regras caso fosse mero órgão auxiliar do Poder Legislativo, a ele subordinado e sujeito às determinações dele oriundas" 389 .

384 BRITTO, Carlos Ayres. O regime constitucional dos tribunais de contas. Revista Diálogo Jurídico, Salvador, v. 1, n. 9, p. 1-12, dez. 2001. Disponível em: http://www.direitopublico.com.br. Acesso em: 24 fev. 2017. p. 2.

385 MARANHÃO, Jarbas. A Constituição de 1988 e o Tribunal de Contas: seus primórdios, normas e atribuições. Revista de Informação Legislativa, Brasília, v. 30, n. 119, p. 255-268, jul./set. 1993. p. 260.

386 BRITTO, Carlos Ayres. O regime constitucional dos tribunais de contas. Revista Diálogo Jurídico, Salvador, v. 1, n. 9, p. 1-12, dez. 2001. Disponível em: http://www.direitopublico.com.br. Acesso em: 24 fev. 2017. p. 3.

387 MEDAUAR, Odete. Controle da administração pública pelo tribunal de contas. Revista de Informação Legislativa, Brasília, v. 27, n. 108, p. 101-126, out./dez. 1990. p. 123-124.

388 GUALAZZI, Eduardo Lobo Botelho. Regime jurídico dos tribunais de contas. São Paulo: Revista dos Tribunais, 1992. p. 46-47.

389 CONTI, José Mauricio. Direito financeiro na Constituição de 1988. São Paulo: Oliveira Mendes, 1998. p. 21. 
Sob tais fundamentos, além dos autores já citados, defendem a independência e autonomia dos tribunais de contas, entre outros, Luiz Bernardo Dias Costa, Uadi Lammêgo Bulos, Michel Cury Neto, Nádia Rezende Faria, Luiz Fernando Rodrigues Pinto Junior e Marianna Montebello Willeman ${ }^{390}$.

Portanto, não obstante auxiliarem os parlamentos em seu exercício do controle externo, os tribunais de contas não estão a eles subordinados. São órgãos independentes, de envergadura constitucional, não pertencentes, nem subordinados, a quaisquer dos três clássicos poderes. Apesar de independentes, por óbvio, tais órgãos também devem se sujeitar à accountability financeira e orçamentária pelo Poder Legislativo, conforme apresenta a subseção 3.3.3.1 (p. 286) deste trabalho, e ao controle externo jurisdicional da Administração Pública.

\subsubsection{Os tribunais de contas e a jurisdição}

Tal possibilidade de controle externo jurisdicional sobre a atuação dos tribunais de contas despertou intensa controvérsia na doutrina jurídica, em especial, no tocante à revisão judicial de suas decisões.

A celeuma, conforme José Cretella Júnior, “[...] principiou, em 1934, quando a Constituição Federal, no art. 99, empregou o verbo 'julgar', na seguinte construção: 'e julgará as contas dos responsáveis por dinheiros ou bens públicos”391. Observe-se que o termo “julgar” é utilizado até hoje pela CRFB/1988, na definição das competências atribuídas às cortes de controle externo, conforme se pode verificar em seu artigo 71, inciso II. Com isso, a controvérsia se manteve no atual ordenamento constitucional, como indicou Anna Hilda de Almeida Donadio ${ }^{392}$.

Ainda no ordenamento anterior, Cotrim Neto, considerando, além da utilização constitucional do termo "julgar”, a concessão aos membros dos tribunais de contas de

390 Cf. COSTA, Luiz Bernardo Dias. O tribunal de contas no estado contemporâneo. 2005. 139 f. Dissertação (Mestrado em Direito) - Centro de Ciências Jurídicas e Sociais, Pontifícia Universidade Católica do Paraná, Curitiba, 2005. p. 56; BULOS, Uadi Lammêgo. Curso de direito constitucional. 9. ed. São Paulo: Saraiva, 2015. p. 1237-1238; CURY NETO, Michel. A competência fiscalizatória prévia do tribunal de contas nas licitaçôes públicas. 2012. 105 f. Dissertação (Mestrado em Direito) - Departamento de Direito do Estado, Faculdade de Direito, Universidade de São Paulo, São Paulo, 2012. p. 34; FARIA, Nádia Rezende. Tribunal de contas na Constituição de 1988: controle social e accountability. 2013. 185 f. Dissertação (Mestrado em Direito) - Pontifícia Universidade Católica de Goiás, Goiânia, 2013. p. 123; PINTO JUNIOR, Luiz Fernando Rodrigues. Fiscalização patrimonial da administração pública. 2013. 303 f. Dissertação (Mestrado em Direito) - Departamento de Direito Econômico, Financeiro e Tributário, Faculdade de Direito, Universidade de São Paulo, São Paulo, 2013. p. 109; e WILLEMAN, Marianna Montebello. A accountability democrática e o desenho institucional dos tribunais de contas no Brasil. 2. ed. Belo Horizonte: Fórum, 2020. p. 192-200.

391 CRETELLA JÚNIOR, José. Natureza das decisões do tribunal de contas. Revista de Direito Administrativo, Rio de Janeiro, v. 166, p. 1-16, out./dez. 1986. p. 8-9.

392 DONADIO, Anna Hilda de Almeida. Tribunal de contas: competência, ação fiscalizadora e princípios norteadores. 1993. 157 f. Dissertação (Mestrado em Direito) - Departamento de Direito do Estado, Faculdade de Direito, Universidade de São Paulo, São Paulo, 1993. p. 19. 


\section{-. Contas dos governantes}

garantias, prerrogativas, vencimentos e impedimentos assemelhados aos dos membros do Poder Judiciário, afirmou que "[...] a situação jurídica de que desfruta o Tribunal de Contas do Brasil - mesmo quando a propósito não seja expressa a nossa Constituição - coloca-o na posição de um órgão judicial [...]"393. Por sua vez, Heloísa Helena Antonacio M. Godinho ${ }^{394}$ defende que a jurisdição não é restrita ao sistema judicial e considera que os tribunais de contas exercem jurisdição especial.

Alfredo Buzaid e Themístocles Brandão Cavalcanti lançam as seguintes questões sobre o Tribunal de Contas: "É órgão jurisdicional?”395 "Importaria essa função julgadora em sua equiparação a uma instância judiciária? [...] Poderá haver revisão judicial da decisão do Tribunal que julgar a matéria de sua competência?"396

Segundo Alfredo Buzaid, "Os autores, que adotam a primeira opiniāo, partem da idéia de que o Tribunal de Contas, tendo a função de julgar, exerce por isso mesmo atividade jurisdicional, que é própria e específica dos Tribunais"397. Na verdade, como ensina, deve-se diferenciar a atribuição de julgar da atividade jurisdicional, pois, "[...] a atribuição de julgar não é sempre e necessariamente atividade jurisdicional. Alguns órgãos administrativos e legislativos também julgam, sem ter função jurisdicional [...]"398. José Cretella Júnior destacou que "No Brasil, emprega-se, a todo instante, o vocábulo 'julgamento’, quando se fala em ‘julgamento’ de concurso, ‘julgamento’ de licitação"399.

Alfredo Buzaid ${ }^{400}$ afirmou que a função jurisdicional se distingue da administrativa porque aquela é uma atividade de substituição. Nesse sentido, baseados na doutrina de Giuseppe Chiovenda ${ }^{401}$, os processualistas brasileiros, como Marcelo Abelha

393 COTRIM NETO, A. B. O tribunal de contas e o aperfeiçoamento do estado de direito. Revista de Informação Legislativa, Brasília, v. 19, n. 76, p. 153-164, out./dez. 1982. p. 162.

394 GODINHO, Heloísa Helena Antonacio M. Ideias no lugar: as decisões condenatórias proferidas pelos tribunais de contas. SARQUIS, Alexandre Manir Figueiredo. Citação e revelia no processo de contas. In: LIMA, Luiz Henrique; SARQUIS, Alexandre Manir Figueiredo (Coord.). Processos de controle externo: estudos de ministros e conselheiros substitutos dos tribunais de contas. Belo Horizonte: Fórum, 2019. p. 220-222.

395 BUZAID, Alfredo. O tribunal de contas no Brasil. Revista da Faculdade de Direito da Universidade de São Paulo, São Paulo, v. 62, n. 2, p. 37-62, 1967. p. 47.

396 CAVALCANTI, Themístocles Brandão. O tribunal de contas - órgão constitucional - funções próprias e funçôes delegadas. Revista de Direito Administrativo, Rio de Janeiro, v. 109, p. 1-10, 1972. p. 7-8.

397 BUZAID, Alfredo. O tribunal de contas no Brasil. Revista da Faculdade de Direito da Universidade de São Paulo, São Paulo, v. 62, n. 2, p. 37-62, 1967. p. 49.

398 BUZAID, Alfredo. O tribunal de contas no Brasil. Revista da Faculdade de Direito da Universidade de São Paulo, São Paulo, v. 62, n. 2, p. 37-62, 1967. p. 49.

399 CRETELLA JÚNIOR, José. Natureza das decisões do tribunal de contas. Revista de Direito Administrativo, Rio de Janeiro, v. 166, p. 1-16, out./dez. 1986. p. 9.

400 BUZAID, Alfredo. O tribunal de contas no Brasil. Revista da Faculdade de Direito da Universidade de São Paulo, São Paulo, v. 62, n. 2, p. 37-62, 1967. p. 49-50.

401 CHIOVENDA, Giuseppe. Istituzioni di diritto processuale civile. Napoli: Eugenio Jovene, 1920. 
Rodrigues ${ }^{402}$, destacam a substituição da vontade das partes entre as características marcantes da jurisdição.

Themístocles Brandão Cavalcanti ${ }^{403}$ defendia que, como há possibilidade de revisão judicial de suas decisões, os tribunais de contas compõem uma instância puramente administrativa, portanto, não jurisdicional. Ao tratar o assunto, Vitor Rolf Laubé relembra que, "[...] no regime jurídico constitucional brasileiro, a jurisdição é una. Ela somente é acometida aos órgãos do Poder Judiciário discriminados no art. 92 da Constituição" 404 , o que claramente não é o caso das cortes de controle externo, previstas no artigo 71 da CRFB/1988.

Os autores estão cobertos de razão, pois, conforme estabelece o artigo $5^{\circ}$, inciso XXXV, da CRFB/1988, "a lei não excluirá da apreciação do Poder Judiciário lesão ou ameaça a direito" ${ }^{\text {405. }}$. Portanto, as decisões dos tribunais de contas estão sujeitas a impugnação no Judiciário.

Por isso, como assevera Eduardo Lobo Botelho Gualazzi, "Sob qualquer aspecto, formal ou material, o Tribunal de Contas não exerce jurisdição stricto sensu, com a definitividade da coisa julgada [...], no Brasil: não há, pois, como juridicamente considerá-lo 'órgão judicial"'\$06. No mesmo sentido é a lição de José Cretella Júnior, para quem "Nenhuma das tarefas ou atividades do Tribunal de Contas configura atividade jurisdicional [...]” e "[...] a atribuição do Tribunal de Contas é 'meramente administrativa', sendo a Corte de Contas classificada como 'órgão administrativo independente" "'407. Outrossim, assiste razão a José dos Santos Carvalho Filho ${ }^{408}$, quando ensina que sua função é eminentemente administrativa, e a José Afonso da Silva, segundo quem o tribunal de contas é “[...] órgão técnico, e suas decisões são administrativas, não jurisdicionais [...]"409.

Portanto, quando adiante, especialmente na subseção 2.6 .8 (p. 157) deste trabalho, referir-se à função judicante dos tribunais de contas, não se está a afirmar que eles

402 RODRIGUES, Marcelo Abelha. Manual de direito processual civil. 5. ed. São Paulo: Revista dos Tribunais, 2010. p. 81-82.

403 CAVALCANTI, Themístocles Brandão. O tribunal de contas - órgão constitucional - funções próprias e funções delegadas. Revista de Direito Administrativo, Rio de Janeiro, v. 109, p. 1-10, 1972. p. 7-8.

404 LAUBÉ, Vitor Rolf. Considerações acerca da conformação constitucional do tribunal de contas. Revista de Informação Legislativa, Brasília, v. 29, n. 113, p. 307-326, jan./mar. 1992. p. 316-317.

405 BRASIL. Constituição (1988). Constituição da República Federativa do Brasil. Disponível em: http:// www.planalto.gov.br/ccivil_03/Constituicao/Constituicao.htm. Acesso em: 2 dez. 2019.

406 GUALAZZI, Eduardo Lobo Botelho. Regime jurídico dos tribunais de contas. São Paulo: Revista dos Tribunais, 1992. p. 182.

407 CRETELLA JÚNIOR, José. Natureza das decisões do tribunal de contas. Revista de Direito Administrativo, Rio de Janeiro, v. 166, p. 1-16, out./dez. 1986. p. 7; 13.

408 CARVALHO FILHO, José dos Santos. Manual de direito administrativo. 33. ed. São Paulo: Atlas, 2019. p. 1079.

409 SILVA, José Afonso da. Curso de direito constitucional positivo. 40. ed. São Paulo: Malheiros, 2017. p. 767. 


\section{-• Contas dos governantes}

detêm função jurisdicional, mas julgam administrativamente, como se julga um processo administrativo disciplinar, por exemplo. Nesse sentido, a distinção terminológica realizada por Marques Oliveira ${ }^{410}$.

A partir da conclusão de que as cortes de controle externo não são órgãos judiciais, tendo em consideração que tampouco são órgãos legislativos, pode-se dizer que eles são órgãos administrativos. Conquanto se reconheça que esse critério negativo de classificação seja passível de críticas e, como advertem Gabriel Heller e Guilherme Carvalho e Sousa ${ }^{411}$, insuficiente para explicar os meios empregados e os fins visados pelo controle externo, a diferenciação em relação à função judicial é suficiente para os fins a que se destina esta subseção, no âmbito deste trabalho.

Logo, posta a questão sobre se as cortes de contas são órgãos independentes, a resposta adequada é positiva, conquanto sejam instituições não jurisdicionais, entidades administrativas, técnicas. Constituindo instituições administrativas independentes, elas não exercem função judicial e suas decisões não são, propriamente, jurisdicionais.

\subsubsection{Processos de controle externo}

Carlos Ayres Britto defende que "[...] os processos instaurados pelos Tribunais de Contas têm sua própria ontologia. São processos de contas, e não processos parlamentares, nem judiciais, nem administrativos”‘12. Não o são porque, segundo afirma “[...] não julgam da própria atividade [...], mas da atividade de outros órgãos, outros agentes públicos, outras pessoas, enfim. Sua atuação é conseqüência de uma precedente atuação [...], e não um proceder originário" ${ }^{\prime 13}$.

Seu argumento e posição são acolhidos por Doris de Miranda Coutinho ${ }^{414}$ e Alexandre Manir Figueiredo Sarquis ${ }^{415}$, que, contudo, reconhecem que a maioria da doutrina considera os processos instaurados nos tribunais de contas como espécie do

410 OLIVEIRA, Marques. O tribunal de contas e os limites da "res veredicta" e o contencioso administrativo. Revista de Informação Legislativa, Brasília, v. 19, n. 75, p. 201-226, jul./set. 1982. p. 206.

411 HELLER, Gabriel; SOUSA, Guilherme Carvalho e. Função de controle externo e função administrativa: separação e colaboração na Constituição de 1988. Revista de Direito Administrativo, Rio de Janeiro, v. 278, n. 2, p. 71-96, maio/ago. 2019. DOI: 10.12660/rda.v278.2019.80049. p. 83-91.

412 BRITTO, Carlos Ayres. O regime constitucional dos tribunais de contas. Revista Diálogo Jurídico, Salvador, v. 1, n. 9, p. 1-12, dez. 2001. Disponível em: http://www.direitopublico.com.br. Acesso em: 24 fev. 2017. p. 10.

413 BRITTO, Carlos Ayres. O regime constitucional dos tribunais de contas. Revista Diálogo Jurídico, Salvador, v. 1, n. 9, p. 1-12, dez. 2001. Disponível em: http://www.direitopublico.com.br. Acesso em: 24 fev. 2017. p. 10.

414 COUTINHO, Doris T. P. C. de Miranda. Uniformização da legislação dos tribunais de contas. Revista de Informação Legislativa, Brasília, v. 53, n. 212, p. 181-201, out./dez. 2016. p. 193.

415 SARQUIS, Alexandre Manir Figueiredo. Citação e revelia no processo de contas. In: LIMA, Luiz Henrique; SARQUIS, Alexandre Manir Figueiredo (Coord.). Processos de controle externo: estudos de ministros e conselheiros substitutos dos tribunais de contas. Belo Horizonte: Fórum, 2019. p. 186. 
processo administrativo. Emerson Cesar da Silva Gomes ${ }^{416}$ também distingue tais processos - que ele denomina "processo contábil" - dos processos administrativos. Para distinguir os processos que tramitam nas cortes de controle externo tanto dos processos judiciais quanto dos administrativos, Luiz Henrique Lima $^{417}$ utiliza a distinção entre as esferas administrativa, controladora e judicial, realizada pela Lei n. 13.655, de 25 de abril de 2018.

Entretanto, ao menos para os fins aos quais se destina esta subseção, no âmbito deste trabalho, tal distinção é desnecessária. É que, sua função, assim como a administrativa e diferentemente da jurisdicional - segundo notas diferenciadoras apresentadas por Odete Medauar ${ }^{418}$-, não tem o caráter de substitutividade e seus atos não são revestidos da imutabilidade decorrente da coisa julgada.

Nesse sentido, Benjamin Zymler defende que o tribunal de contas “[...] deve fazer uso, exemplarmente, do processo administrativo como meio para ultimação dos atos administrativos inseridos em sua órbita de atribuiçôes finalísticas [...]"ł19. Com ele, Luciano Ferraz ${ }^{420}$ e Fernando Quadros da Silva e Isabel Arruda Quadros ${ }^{421}$, também, classificam os processos que correm nas cortes de contas como administrativos.

Pelo exposto, os tribunais de contas brasileiros - agências colegiadas especializadas na accountability horizontal da gestão financeira e orçamentária -, que exercem o controle externo precipuamente técnico da Administração Pública, são instituições estatais independentes - não pertencentes, nem subordinadas a quaisquer dos três clássicos poderes, embora auxiliem o Poder Legislativo na sua função de controle externo político -, não dotados de jurisdição, que atuam administrativamente, tomando suas decisões em sede de processo administrativo, o qual se denomina neste

416 GOMES, Emerson Cesar da Silva. Responsabilidade financeira: uma teoria sobre a responsabilidade no âmbito dos tribunais de contas. 2009. 379 f. Dissertação (Mestrado em Direito) - Departamento de Direito Econômico, Financeiro e Tributário, Faculdade de Direito, Universidade de São Paulo, São Paulo, 2009. f. 363.

417 LIMA, Luiz Henrique. Anotações sobre a singularidade do processo de controle externo nos tribunais de contas: similaridades e distinçôes com o processo civil e penal. In: LIMA, Luiz Henrique; SARQUIS, Alexandre Manir Figueiredo (Coord.). Processos de controle externo: estudos de ministros e conselheiros substitutos dos tribunais de contas. Belo Horizonte: Fórum, 2019. p. 17-18.

418 MEDAUAR, Odete. A processualidade no direito administrativo. 2. ed. São Paulo: Revista dos Tribunais, 2008. p. 49-58.

419 ZYMLER, Benjamin. Processo administrativo no Tribunal de Contas da União. In: BRASIL. Tribunal de Contas da União. Prêmio Serzedello Corrêa 1996: Monografias vencedoras. Brasília: Instituto Serzedello Corrêa, Serviço de Editoração e Publicações, 1997. p. 145.

420 FERRAZ, Luciano. Due process of law e parecer prévio das contas de contas. Revista Gestão e Controle, Porto Velho, a. 1, n. 2, p. 73-96, jul./dez. 2013. Disponível em: http://ojs.tce.ro.gov.br/ojs/index. php/TCE-RO/article/view/23/23. Acesso em: 5 set. 2019. p. 80.

421 SILVA, Fernando Quadros da; QUADROS, Isabel Arruda. Apreciação das contas do prefeito: controle judicial dos atos das câmaras de vereadores. Interesse Público - IP, Belo Horizonte, v. 17, n. 89, p. 227 236, jan./fev. 2015. p. 228-229. 


\section{-• Contas dos governantes}

trabalho processo administrativo de controle externo ou, simplesmente, processo de controle externo ${ }^{422}$.

De qualquer modo, até autores que diferenciam os processos dos tribunais de contas dos processos administrativos, como Milene Dias da Cunha ${ }^{423}$, reconhecem a aplicabilidade, a eles, dos princípios gerais administrativos e processuais administrativos.

Quanto aos princípios administrativos, Odete Medauar esclarece que “[...] os princípios constitucionais da Administração Pública em geral, previstos no caput do art. 37, aplicam-se também ao processo administrativo [...]"424 . Portanto, aplicam-se ao processo administrativo os princípios da legalidade, impessoalidade, moralidade, publicidade e eficiência.

Com a intenção de traduzir tais princípios gerais da administração pública em valores intermediários, situados entre eles e as regras processuais pormenorizadas, Thiago Marrara ${ }^{425}$ elenca como princípios do processo administrativo a ampla defesa, o contraditório, a gratuidade, a transparência, a oficialidade, o formalismo mitigado, a isonomia, a boa-fé e proteção da confiança e a razoabilidade.

O princípio da razoabilidade decorre do artigo $2^{\circ}$ da Lei n. 9.784, de 29 de janeiro de 1999, conhecida como Lei Geral de Processo Administrativo (LGPA) federal, e do novo parágrafo único do artigo 20 do Decreto-Lei (DL) n. 4.657, de 4 de setembro de 1942, a Lei de Introdução às Normas do Direito Brasileiro (LINDB). Segundo Thiago Marrara ${ }^{426}$, a atuação administrativa é razoável quando observa, simultaneamente, as regras da adequação, da necessidade e da proporcionalidade, tomando por adequada a ação capaz de atingir sua finalidade; por necessária, a menos restritiva dentre as ações adequadas; e por proporcional, aquela cujos benefícios superem seus impactos negativos. Uma expressão do princípio da razoabilidade, estreitamente vinculada ao princípio administrativo geral da eficiência, é o mandamento da razoável duração do processo, previsto no artigo 5º, inciso LXXVIII, da CRFB/1988.

422 Para detalhes a respeito do processo de controle externo e a influência que sofre do princípio do devido processo legal, cf. MOUTINHO, Donato Volkers. Primeiras linhas de uma teoria geral dos recursos nos tribunais de contas. 2011. 295 f. Monografia (Graduação em Direito) - Departamento de Direito, Centro de Ciências Jurídicas e Econômicas, Universidade Federal do Estado do Espírito Santo, Vitória, 2011. p. 29-42.

423 CUNHA, Milene Dias da. Processo dos tribunais de contas: uma posição de permeio entre o administrativo e o judicial e a importância de um eixo estruturante nacional. In: LIMA, Luiz Henrique; SARQUIS, Alexandre Manir Figueiredo (Coord.). Processos de controle externo: estudos de ministros e conselheiros substitutos dos tribunais de contas. Belo Horizonte: Fórum, 2019. p. 133.

424 MEDAUAR, Odete. A processualidade no direito administrativo. 2. ed. São Paulo: Revista dos Tribunais, 2008. p. 140.

425 MARRARA, Thiago. Princípios do processo administrativo. In: BITENCOURT NETO, Eurico; MARRARA, Thiago (Coord.). Processo administrativo brasileiro: estudos em homenagem aos 20 anos da Lei Federal de Processo Administrativo. Belo Horizonte: Fórum, 2020. p. 82.

426 MARRARA, Thiago. O conteúdo do princípio da moralidade: probidade, razoabilidade e cooperação. Revista Digital de Direito Administrativo, Ribeirão Preto, v. 3, n. 1, p. 104-120, 2016. DOI: 10.11606/issn.2319-0558.v3n1p104-120. p. 114. 
A boa-fé e a proteção da confiança foram consagradas em vários dispositivos da LGPA, como os artigos $2^{\circ}$, parágrafo único, inciso IV, $3^{\circ}$, inciso I, e $4^{\circ}$, inciso II. Aplicando as liçōes de Thiago Marrara ${ }^{427}$, percebe-se que tal princípio exige, dos tribunais de contas, o respeito a seus pronunciamentos anteriores sobre determinado tema e veda a aplicação retroativa de nova interpretação a respeito de certa questão. Além disso, exige que as sanções administrativas sejam revisadas diante de novos fatos que mostrem a sua inadequação e o reconhecimento, pelas cortes de contas, da decadência do poder administrativo de anular atos que produzam efeitos benéficos sobre interesses de administrados.

O princípio da isonomia, por sua vez, impede que as cortes de controle externo atuem com base em simpatias ou antipatias, vingança ou favorecimento, como adverte Odete Medauar ${ }^{428}$. São expressões desse princípio as normas de impedimento ou suspeição, existentes nas leis orgânicas e regimentos internos dos tribunais de contas.

A LGPA, em seu artigo $2^{\circ}$, parágrafo único, incisos IV e VIII, adotou, também, o princípio do formalismo mitigado, ou moderado. Em razão dele, como ensina Odete Medauar ${ }^{429}$, os ritos previstos para os processos de controle externo devem ser tão simples quanto possível, desde que propiciem às cortes de contas suficiente certeza para suas decisões e respeitem os direitos das partes, garantindo-lhes o contraditório e a ampla defesa. Além disso, como observa Evandro Martins Guerra, o formalismo mitigado "[...] favorece a busca pela verdade material" $"$ "

Pelo princípio da oficialidade, as cortes de contas podem empreender ações de controle externo sem que sejam provocadas, mediante denúncias, representaçóes ou prestações de contas. Para José dos Santos Carvalho Filho ${ }^{431}$, em razão do princípio, cabe-lhes atuar e decidir por conta própria, sem que estejam adstritas às alegações das partes suscitadas no processo.

O princípio da transparência, conforme Thiago Marrara ${ }^{432}$, exige que os tribunais de contas garantam a todos os cidadãos amplo acesso às informações dos proces-

427 MARRARA, Thiago. A boa-fé do administrado e do administrador como fator limitativo da discricionariedade administrativa. Revista de Direito Administrativo, Rio de Janeiro, v. 259, p. 207-247, jan./ abr. 2012. Disponível em: http://www.bidforum.com.br/bid/PDI0006.aspx?pdiCntd=80499. Acesso em: 24 out. 2019. p. 13-22 (Versão digital).

${ }^{428}$ MEDAUAR, Odete. A processualidade no direito administrativo. 2. ed. São Paulo: Revista dos Tribunais, 2008. p. 93.

429 MEDAUAR, Odete. A processualidade no direito administrativo. 2. ed. São Paulo: Revista dos Tribunais, 2008. p. 131-132.

430 GUERRA, Evandro Martins. Controle externo da administração pública. 4. ed. Belo Horizonte: Fórum, 2019. p. 224.

431 CARVALHO FILHO, José dos Santos. Manual de direito administrativo. 33. ed. São Paulo: Atlas, 2019. p. 1082-1083.

432 MARRARA, Thiago. Princípios do processo administrativo. In: BITENCOURT NETO, Eurico; MARRARA, Thiago (Coord.). Processo administrativo brasileiro: estudos em homenagem aos 20 anos da Lei Federal de Processo Administrativo. Belo Horizonte: Fórum, 2020. p. 94. 


\section{-• Contas dos governantes}

sos de controle externo, resguardadas as hipóteses em que o sigilo é imprescindível à segurança da sociedade ou do Estado e respeitadas a intimidade, a vida privada, a honra e a imagem daqueles cuja atuação é objeto de controle, por conta, respectivamente, dos artigos 23 e 31 da Lei n. 12.527, de 18 de novembro de 2011, denominada Lei de Acesso à Informação. Por outro lado, por aplicação do princípio da gratuidade, previsto expressamente no artigo $2^{\circ}$, parágrafo único, inciso XI, da LGPA, não são cobrados quaisquer taxas ou emolumentos nos processos de controle externo.

A aplicação dos princípios da ampla defesa e do contraditório aos processos administrativos, em geral, e aos processos de controle externo, em particular, decorre diretamente do estatuído no artigo 5º inciso LV, da CRFB/1988.

Segundo Agustín Gordillo, a garantia de ampla defesa "Não deve se transformar em um 'mero ritual', 'rotineiro e externo', apenas 'uma aparência formal de defesa' ou 'mera formalidade da intimação dos litigantes', mas 'consiste na possibilidade de sua efetiva participação útil' no processo administrativo" ${ }^{\prime 33}$. Desse modo, em razão da ampla defesa, considerando as liçôes de Hely Lopes Meirelles ${ }^{434}$ e Cármen Lúcia Antunes Rocha ${ }^{435}$, os tribunais de contas devem não apenas cientificar os interessados a respeito dos processos que podem lhes afetar, como lhes dar a conhecer tudo o que se afirma contra os seus interesses, lhes dar oportunidade para contestar as informações que lhes prejudiquem, de produzir provas em seu favor, de acompanhar a instrução e se utilizar dos recursos cabíveis.

Pelo princípio do contraditório, os interessados no processo de controle externo devem ter "[...] a faculdade de manifestar o próprio ponto de vista ou argumentos próprios ante fatos, documentos ou pontos de vista apresentados por outrem”436, como ensina Odete Medauar. Segundo Alexandre Aroeira Salles ${ }^{437}$, tais interessados têm direito a serem julgados por uma corte independente e imparcial, a conhecer e participar dos atos processuais, manifestando seu ponto de vista ante fatos, documentos ou argumentos apresentados por outros, a produzirem prova e contraprova, à igualdade de meios processuais para fazer valer a sua opinião e a influir verdadeiramente na decisão. Dele, também, decorrem, segundo Jorge Ulisses Jacoby Fernandes ${ }^{438}$ e Benja-

433 GORDILLO, Agustín. Tratado de derecho administrativo y obras selectas. t. 2. La defensa del usuário y del administrado. Buenos Aires: Fundación de Derecho Administrativo, 2014. p. 407.

434 MEIRELLES, Hely Lopes. Direito administrativo brasileiro. 43. ed. São Paulo: Malheiros, 2018. p. 880.

435 ROCHA, Cármen Lúcia Antunes. Princípios constitucionais do processo administrativo brasileiro. Revista de direito administrativo, Rio de Janeiro, v. 209, p. 189-222, 1997. p. 208.

436 MEDAUAR, Odete. A processualidade no direito administrativo. 2. ed. São Paulo: Revista dos Tribunais, 2008. p. 101.

437 SALLES, Alexandre Aroeira. O princípio do contraditório necessário aos processos administrativos e aos processos nos tribunais de contas. Revista de Direito Administrativo, Rio de Janeiro, v. 277, n. 3, p. 169-208, set./dez. 2018. DOI: 10.12660/rda.v277.2018.77681. p. 196-201.

438 FERNANDES, Jorge Ulisses Jacoby. Princípios do contraditório e da ampla defesa: especificidades na ação do controle externo. Revista do Tribunal de Contas do Estado de Minas Gerais, Belo Horizonte, v. 46, n. 1, p. 57-70, 2003. p. 67. 
min Zymler ${ }^{439}$, a possibilidade de os interessados assistirem à apreciação ou julgamento dos processos de controle externo que lhes interessam e de constituírem procurador, advogado ou não, para atuar no processo.

Diante do exposto, a sucinta apresentação realizada é suficiente para concluir, com segurança, que os princípios da ampla defesa, do contraditório, da gratuidade, da transparência, da oficialidade, do formalismo mitigado, da isonomia, da boa-fé e proteção da confiança e da razoabilidade se aplicam inteiramente aos processos de controle externo.

Apesar de atuarem administrativamente, tomando suas decisões em sede de processo administrativo de controle externo, o exercício, pelas cortes de controle externo, da accountability horizontal em relação à gestão financeira e orçamentária da Administração Pública não é, primordialmente, regulada pelo direito administrativo, mas pelo direito financeiro. Desse modo, a próxima subseção se dedica a situar a accountability financeira e orçamentária, em geral, e o controle externo a cargo dos tribunais de contas, em particular, entre os ramos do direito público, bem como identificar quais são e qual a origem das normas que regulam a sua atuação.

\subsubsection{Normas de direito financeiro e cortes de contas}

Gaston Jèze ${ }^{440}$ defendia que os três objetos essenciais das finanças públicas seriam a despesa, a receita e a utilização das receitas para cobrir as despesas. O direito financeiro, por seu turno, de acordo com Geraldo de Camargo Vidigal ${ }^{441}$, rege as matérias pertinentes às preocupações das finanças públicas, seja estabelecendo normas para a elaboração dos orçamentos, seja definindo e regulando fontes de receita, seja discriminando despesas, seja disciplinando o crédito público.

Geraldo Ataliba conceituava o direito financeiro como "[...] o conjunto de normas jurídicas que devem ser obedecidas, assim pelo Estado como pelos cidadóes, no respeitante à atividade financeira do poder público"\$42. Para Aliomar Baleeiro, esse ramo do direito “[...] nasce da própria Constituição e é da própria estrutura básica do Estado. Não poderíamos compreender, pelo menos no nosso tipo de civilização, o Estado sem uma base financeira" ${ }^{\text {443 }}$.

439 ZYMLER, Benjamin. Processo administrativo no Tribunal de Contas da União. In: BRASIL. Tribunal de Contas da União. Prêmio Serzedello Corrêa 1996: Monografias vencedoras. Brasília: Instituto Serzedello Corrêa, Serviço de Editoração e Publicações, 1997. p. 188.

${ }^{440}$ JĖZE, Gaston. Cours de finances publiques: 1932-1933. Paris: Marcel Giard, 1933. p. 2.

${ }^{441}$ VIDIGAL, Geraldo de Camargo. Fundamentos do direito financeiro. São Paulo: Revista dos Tribunais, 1972. p. 58.

${ }_{442}$ ATALIBA, Geraldo. Normas gerais de direito financeiro. Revista de Direito Administrativo, Rio de Janeiro, v. 82, p. 39-60, 1964. p. 40.

${ }^{443}$ SÁ FILHO; BALEEIRO, Aliomar; VIANA, Arízio de; CANTO, Gilberto de Ulhôa; ALMIRO, Affonso. Normas gerais de direito financeiro. Rio de Janeiro: Ediçôes Financeiras, 1950. p. 14. 


\section{•. Contas dos governantes}

Nesse sentido, de acordo com Achile Donato Giannini ${ }^{444}$ e Mario Pugliese ${ }^{445}$, o direito financeiro se estende por toda a atividade financeira do Estado, desde a arrecadação de recursos públicos, inclusive por meio do acesso ao crédito público, passando pela sua gestão, até sua aplicação. Carlos Alberto Alves de Carvalho Pinto ${ }^{446}$ destacava que, também, está no escopo do direito financeiro a regulamentação da contabilidade pública.

Segundo Sá Filho, o direito financeiro contém as regras referentes “[...] ao desempenho das atribuições de todos os encarregados da guarda e aplicação dos dinheiros nacionais; à tomada de suas contas; e à maneira de se lhes fazer efetiva a responsabilidade" 447 . Observe-se que, nesses termos, ele incluiu no direito financeiro as normas referentes à accountability financeira e orçamentária.

Carlos M. Giuliani Fonrouge ${ }^{448}$ e Ruy Barbosa Nogueira ${ }^{449}$, também, incluíram o controle dos gastos públicos como objeto do direito financeiro. Outrossim, conforme Geraldo Ataliba, "São partes, pois, do Direito Financeiro o Direito Tributário e as disciplinas Jurídicas do orçamento, fiscalização e contrôle orçamentário, da contabilidade pública e do crédito público" ${ }^{350}$.

Entre os doutrinadores contemporâneos, é pacífico que as normas relativas à fiscalização financeira e orçamentária, inclusive aquelas referentes ao controle externo da Administração Pública, empreendido pelos tribunais de contas, são objetos do direito financeiro ${ }^{451}$. Desse modo, não restam dúvidas de que é o direito financeiro o ramo da ciência jurídica que regula as atividades desenvolvidas pelos tribunais de contas brasileiros, no exercício da accountability financeira e orçamentária da Administração Pública, mediante controle externo.

${ }^{444}$ GIANNINI, Achile Donato. Elementi di diritto finanziario. Milano: Giuffrè, 1945. p. 3-4.

445 PUGLIESE, Mario. Istituzioni di diritto finanziario: diritto tributario. Padova: Cedam, 1937. p. 4-7.

446 CARVALHO PINTO, Carlos Alberto Alves de. Normas gerais de direito financeiro. São Paulo: Prefeitura do Município de São Paulo, 1949. p. 14.

447 SÁ FILHO; BALEEIRO, Aliomar; VIANA, Arízio de; CANTO, Gilberto de Ulhôa; ALMIRO, Affonso. Normas gerais de direito financeiro. Rio de Janeiro: Ediçōes Financeiras, 1950. 104 p. p. 20.

448 FONROUGE, Carlos M. Giuliani. Derecho financiero. 2. ed. v. I. Buenos Aires: Depalma, 1970. p. $35 ; 51$.

449 NOGUEIRA, Ruy Barbosa. Direito financeiro: curso de direito tributário. São Paulo: J. Bushatsky, 1964.p. 3.

450 ATALIBA, Geraldo. Normas gerais de direito financeiro e tributário e autonomia dos Estados e Municípios. Revista de Direito Público, v. III, n. 10, p. 45-80, 1969. p. 52.

451 Cf. TORRES, Heleno Taveira. Direito constitucional financeiro: teoria da constituição financeira. São Paulo: Revista dos Tribunais, 2014. p. 35; 55; OLIVEIRA, Regis Fernandes de. Curso de direito financeiro. 7. ed. São Paulo: Revista dos Tribunais, 2015. p. 202; CONTI, José Mauricio. O planejamento orçamentário da Administração Pública no Brasil. 2017. 556 p. Tese (Professor Titular) Faculdade de Direito, Universidade de São Paulo, São Paulo, 2017. p. 45; e SCAFF, Fernando Facury. Orçamento republicano e liberdade igual: ensaio sobre direito financeiro, república e direitos fundamentais no Brasil. Belo Horizonte: Fórum, 2018. p. 94. 
Logo, em se tratando de accountability da gestão financeira e orçamentária da Administração Pública - enquanto matéria de direito financeiro -, por força do artigo 24, inciso I, da CRFB/1988, competirá à União, aos estados e ao DF legislar concorrentemente. Aos municípios, por seu turno, competirá suplementar a legislação federal e a estadual no que couber, como prevê o artigo 30, inciso II, da CRFB/1988.

Essa distribuição de competências em matéria de direito financeiro é decorrente da adoção, pelo Brasil, da forma federativa de Estado, como fica claro desde o artigo $1^{\circ}$ da CRFB/1988. Nesse sentido, como destacou Carlos Alberto Alves de Carvalho Pinto, "O sistema federativo é, assim, um princípio estrutural de nossa organização, e êsse sistema se caracteriza exatamente pela distribuição do exercício da soberania popular entre a entidade central e as entidades locais" ${ }^{\prime 452}$.

É que, em tese, como ensinava Geraldo Ataliba, numa federação vale "[...] o princípio da 'igualdade entre a União e os Estados'. Nem a União está acima dos Estados, nem os Estados estão acima da União. São ambos iguais e, pois, reciprocamente autônomos" ${ }^{\prime \prime 53}$.

Enquanto autônomos, os entes federados são dotados de autonomia legislativa. Tal autonomia, como destaca José Mauricio Conti ${ }^{454}$, ao lado da descentralização política, das autonomias administrativa e financeira e da participação dos entes federados na formação da vontade nacional, é requisito para a própria existência do Estado federal. Deve-se ter em mente, como destaca José Afonso da Silva ${ }^{455}$, que a repartição de competências entre os entes federados é norteada pelo princípio da predominância do interesse, cabendo à União as matérias e questôes em que predominarem o interesse geral, nacional, e aos estados e municípios aquelas de predominante interesse regional e local, respectivamente.

Desse modo, por um lado, a CRFB/1988 institui o modelo de sistema de accountability financeira e orçamentária a ser obrigatoriamente seguido por todas as esferas da federação. Por outro, tendo em vista a necessidade de integração do conjunto normativo referente a tal sistema e considerando que a fiscalização financeira e orçamentária é matéria de direito financeiro, onde operam a autonomia legislativa e a concorrência de competências, é esperado que coexistam e se relacionem diversas normas, emitidas por diferentes fontes legislativas.

452 CARVALHO PINTO, Carlos Alberto Alves de. Normas gerais de direito financeiro. São Paulo: Prefeitura do Município de São Paulo, 1949. p. 33.

453 ATALIBA, Geraldo. Federação. Revista de Direito Público, v. XX, n. 81, p. 172-181, 1987. p. 173.

${ }^{454}$ CONTI, José Mauricio. A autonomia financeira do Poder Judiciário. 2. ed. São Paulo: Blucher, 2019. p. 205.

455 SILVA, José Afonso da. Curso de direito constitucional positivo. 40. ed. São Paulo: Malheiros, 2017. p. 482. 


\section{-. Contas dos governantes}

Assim, zelando pela coerência do sistema normativo, o legislador constitucional, no artigo 24, $\$ 1^{\circ}$, da CRFB/1988, atribuiu à União a competência para editar normas gerais de direito financeiro. Elas, de acordo com Fernando Facury Scaff, servem para garantir alguma unidade nesse sistema descentralizado e, desse modo, "[...] vinculam todos os entes federados a adotar uma conduta minimamente uniforme em certos temas" ${ }^{\text {”/456 }}$.

Segundo José Maria Arruda de Andrade, “[...] além do direcionamento aos entes da República Federativa, uma norma geral deve tratar de temas que não sejam notadamente específicos”57. A grande dificuldade, como destaca José Mauricio Conti, está em definir o alcance exato dessas normas, pois, como explica,

[...] se este alcance for diminuto, pouco ou nada resultará para sua finalidade, qual seja, estabelecer as diretrizes a serem cumpridas por todas as esferas de governo, conferindo maior coesão e harmonia ao ordenamento jurídico do Estado Federal; se o alcance for excessivo, pouco ou nada restará de autonomia legislativa para os entes que compõem a Federação ${ }^{458}$.

Nos ordenamentos constitucionais de 1946 e 1967, respectivamente, Arízio de Viana ${ }^{459}$ e Geraldo Ataliba ${ }^{460}$ se mostraram extremamente críticos em relação à edição de normas gerais, pela União, referentes à previsão, execução e controle do orçamento, por considerarem que a livre disposição sobre seu orçamento é requisito para a autonomia dos entes federados. Carlos Alberto Alves de Carvalho Pinto ${ }^{461}$ e Maria do Rosário Esteves ${ }^{462}$ submeteram a edição de normas gerais, respectivamente, à generalidade e à excepcionalidade.

Para Geraldo Ataliba ${ }^{463}$, em matéria de orçamento e contas, a autonomia de estados e municípios deve ser valorizada. Pois, como ensina, se o orçamento - enquanto instru-

456 SCAFF, Fernando Facury. O que são normas gerais de direito financeiro? In: MARTINS, Ives Gandra da Silva; MENDES, Gilmar Ferreira; NASCIMENTO, Carlos Valder. Tratado de direito financeiro. v. 1, São Paulo: Saraiva, 2013. p. 31.

457 ANDRADE, José Maria Arruda de. Normas gerais, nacionais, competência legislativa e o federalismo fiscal. Revista Brasileira de Estudos Constitucionais. Belo Horizonte, a. 2, n. 6, p. 67-86, abr./jun. 2008. p. 73.

458 CONTI, José Mauricio. A autonomia financeira do Poder Judiciário. 2. ed. São Paulo: Blucher, 2019. p. 206.

459 SÁ FILHO; BALEEIRO, Aliomar; VIANA, Arízio de; CANTO, Gilberto de Ulhôa; ALMIRO, Affonso. Normas gerais de direito financeiro. Rio de Janeiro: Edições Financeiras, 1950. p. 40.

460 ATALIBA, Geraldo. Normas gerais de direito financeiro e tributário e autonomia dos Estados e Municípios. Revista de Direito Público, v. III, n. 10, p. 45-80, 1969. p. 52-53.

461 CARVAlHO PINTO, Carlos Alberto Alves de. Normas gerais de direito financeiro. São Paulo: Prefeitura do Município de São Paulo, 1949. p. 20; 31.

462 ESTEVES, Maria do Rosário. Normas gerais de direito tributário. São Paulo: Max Limonad, 1997. p. 97-98.

463 ATALIBA, Geraldo. Normas gerais de direito financeiro. Revista de direito administrativo, Rio de Janeiro, v. 82, p. 39-60, 1964. p. 40; 50; 56. 
mento da ação política dos estados e municípios, condição de sua autonomia - deve ser elaborado tão livremente quanto possível, o controle e a fiscalização da execução orçamentária, tratando-se de matéria acessória ao orçamento, deve ter a mesma sorte.

Embora diante da atual ordem constitucional não se afigure razoável defender a impossibilidade de edição de normas gerais, pela União, referente à accountability financeira e orçamentária da Administração Pública, não é despiciendo o risco de essas normas invadirem a competência dos demais entes de outras esferas federativas. $\mathrm{Na}$ realidade, como destaca Denise Cristina Vasques, "Em um País de história e tradição centralizadoras [...], a tendência natural é que a União regule inteiramente (ou quase) tais matérias, sob a alegação de que legisla sobre normas gerais"64.

Segundo ela ${ }^{465}$, é comum a União utilizar o mesmo veículo introdutório de normas jurídicas - na concepção que Tárek Moysés Moussallem ${ }^{466}$ empresta à locução para estabelecer algumas normas gerais, aplicáveis a todos os entes, e outras normas específicas, aplicáveis somente à União. Ocorre que, enquanto, no caso de algumas normas, a categorização entre normas gerais ou específicas é clara, no caso de outras, a classificação é muito dependente da subjetividade do intérprete.

Nesses casos, como explica a autora, “[...] deverá prevalecer a decisão do legislador nacional; isto é, caberá respeitar sua atuação legislativa e pressupor seu respeito ao limite constitucional a ele imposto - o de editar normas gerais -, caracterizando a norma como tal" 467 . Tendo analisado um conjunto de leis nacionais que veiculam normas gerais, ela conclui que, na maioria dessas leis, "[...] o legislador nacional ultrapassa, algumas vezes, a fronteira a ele imposta [...] e, sob a alegação de que elabora normas gerais, acaba por adentrar na competência legislativa complementar dos Estados-membros [... ${ }^{3468}$.

Conquanto tenha dedicado toda uma seção à fiscalização financeira e orçamentária da Administração Pública - artigos 70 a 75 da CRFB/1988, fazendo jus à alcunha de

464 VASQUES, Denise Cristina. Competências legislativas concorrentes: prática legislativa da União e dos estados-membros e jurisprudência do Supremo Tribunal Federal. 2007. 196 f. Dissertação (Mestrado em Direito) - Departamento de Direito do Estado, Faculdade de Direito, Universidade de São Paulo, São Paulo, 2007. p. 60.

465 VASQUES, Denise Cristina. Competências legislativas concorrentes: prática legislativa da União e dos estados-membros e jurisprudência do Supremo Tribunal Federal. 2007. 196 f. Dissertação (Mestrado em Direito) - Departamento de Direito do Estado, Faculdade de Direito, Universidade de São Paulo, São Paulo, 2007. p. 57.

466 MOUSSALLEM, Tárek Moysés. Fontes do direito tributário. 2. ed. São Paulo: Noeses, 2006. p. 119.

467 VASQUES, Denise Cristina. Competências legislativas concorrentes: prática legislativa da União e dos estados-membros e jurisprudência do Supremo Tribunal Federal. 2007. 196 f. Dissertação (Mestrado em Direito) - Departamento de Direito do Estado, Faculdade de Direito, Universidade de São Paulo, São Paulo, 2007. p. 57.

468 VASQUES, Denise Cristina. Competências legislativas concorrentes: prática legislativa da União e dos estados-membros e jurisprudência do Supremo Tribunal Federal. 2007. 196 f. Dissertação (Mestrado em Direito) - Departamento de Direito do Estado, Faculdade de Direito, Universidade de São Paulo, São Paulo, 2007. p. 101. 


\section{•- Contas dos governantes}

"maior fonte do direito financeiro", que lhe atribui Régis Fernandes de Oliveira ${ }^{469}$-, a Constituição de 1988 prevê, desde a promulgação da Emenda Constitucional (EC) n. 40, de 29 de maio de 2003, em seu artigo 163, inciso V, a edição de lei complementar para dispor sobre fiscalização financeira da administração direta e indireta. A LRF, cuja existência é anterior à da EC n. 40/2003, é exemplo de norma geral de direito financeiro, editada mediante lei complementar, que carrega dispositivos relacionados à accountability da gestão financeira e orçamentária da Administração Pública.

A LRF ilustra, também, a dificuldade em definir o alcance adequado às normas gerais, na medida em que, desde a sua edição, é alvo de intensa controvérsia sobre a sua constitucionalidade. Por exemplo, discutiram a constitucionalidade de dispositivos da LRF, veiculados como normas gerais de direito financeiro, a ADPF n. 24 e as ADI $n$. 2.238 , n. 2.241 e n. $2.250^{470}$.

Encontrada a medida correta, se a União deve editar normas gerais que prestigiem a uniformidade nacional, aos estados-membros resta a essencial tarefa de estabelecer "[...] normas complementares adequadas às suas condiçôes locais, em benefício da pluralidade" ${ }^{\text {"’71 }}$, como destaca Denise Cristina Vasques. É a competência suplementar dos estados, prevista no artigo $24, \$ 2^{\circ}$, da CRFB/1998. Não se pode olvidar que há matérias em relação às quais, não obstante lhe caiba essa função, a União não se desincumbe de editar normas gerais. Nesses casos os estados podem legislar plenamente, atendendo suas necessidades normativas até a eventual superveniência de lei federal sobre a matéria, conforme estabelecem os parágrafos $3^{\circ}$ e $4^{\circ}$ do artigo 24 da CRFB/1988.

469 OLIVEIRA, Regis Fernandes de. Curso de direito financeiro. 7. ed. São Paulo: Revista dos Tribunais, 2015. p. 215.

470 Cf. ORDEM DOS ADVOGADOS DO BRASIL. Conselho Federal. Petição inicial na arguição de descumprimento de preceito fundamental n. 24. Brasília, 5 nov. 2001. Disponível em: http://redir. stf.jus.br/estfvisualizadorpub/jsp/consultarprocessoeletronico/ConsultarProcessoEletronico. jsf? seqobjetoincidente=1983411. Acesso em: 19 dez. 2017; PARTIDO COMUNISTA DO BRASIL; PARTIDO SOCIALISTA BRASILEIRO; PARTIDO DOS TRABALHADORES. Petição inicial na ação direta de inconstitucionalidade n. 2.238. Brasília, 29 jun. 2000. Disponível em: http://redir. stf.jus.br/estfvisualizadorpub/jsp/consultarprocessoeletronico/ConsultarProcessoEletronico. jsf? seqobjetoincidente=1829732. Acesso em: 19 dez. 2017; MINAS GERAIS. Assembleia Legislativa do Estado. Petição inicial na ação direta de inconstitucionalidade n. 2.241. Brasília, 4 jul. 2000. Disponível em: http://redir.stf.jus.br/estfvisualizadorpub/jsp/consultarprocessoeletronico/ConsultarProcessoEletronico.jsf? seqobjetoincidente=1830416. Acesso em: 19 dez. 2017; e MINAS GERAIS. Governo do Estado. Petição inicial na ação direta de inconstitucionalidade n. 2.250. Brasília, 20 jul. 2000. Disponível em: http://redir.stf.jus.br/estfvisualizadorpub/jsp/consultarprocessoeletronico/ConsultarProcessoEletronico.jsf? seqobjetoincidente $=1833269$. Acesso em: 19 dez. 2017. Embora o STF, nas seçôes realizadas nos dias 21 e 22 de agosto de 2019, tenha julgado tais açôes, os acórdãos não haviam sido publicados até a data de fechamento deste trabalho.

471 VASQUES, Denise Cristina. Competências legislativas concorrentes: prática legislativa da União e dos estados-membros e jurisprudência do Supremo Tribunal Federal. 2007. 196 f. Dissertação (Mestrado em Direito) - Departamento de Direito do Estado, Faculdade de Direito, Universidade de São Paulo, São Paulo, 2007. p. 49. 
Assim, por exemplo, nas leis orgânicas dos tribunais de contas dos estados, é comum a existência, além das normas referentes à própria organização das cortes de controle externo, de normas relativas à fiscalização financeira e orçamentária da Administração Pública. Esses instrumentos normativos podem conter tanto legislação suplementar às normas gerais nacionais quanto, nas matérias em relação às quais a União não tenha estabelecido a legislação uniformizadora, normas que regulam amplamente a accountability financeira e orçamentária a cargo das cortes de contas.

Além de normas gerais e suplementares, as leis orgânicas dos tribunais de contas contêm normas específicas, somente aplicáveis aos entes federados pelos quais foram emitidas. Isso é verdade, também, para a União, que ao lado da competência de editar normas gerais de direito financeiro, detém a competência para editar normas específicas aplicáveis à accountability da gestão financeira e orçamentária da Administração Pública federal.

Também os municípios, como destaca Maria do Rosário Esteves ${ }^{472}$, têm sua existência e autonomia, inclusive legislativa, derivadas da própria Constituição de 1988. Cabe-lhes tanto legislar sobre os assuntos de interesse local como suplementar a legislação federal e a estadual no que couber, como prevê o artigo 30, incisos I e II, da CRFB/1988. Vale dizer, como explica Tércio Sampaio Ferraz Júnior ${ }^{473}$, nisto se opondo a Fernanda Dias Menezes de Almeida ${ }^{474}$, a legislação suplementar aqui não é para a edição de legislação concorrente, mas decorrente das situações previstas nas normas gerais, regulamentação com o objetivo de precisar seu conteúdo ante as peculiaridades do interesse local.

Assim, os municípios podem editar normas suplementares em matéria de accountability financeira e orçamentária. Aliás, como se vê ao longo deste trabalho, em diversos assuntos é muito importante que as câmaras municipais exerçam sua competência para que a accountability financeira e orçamentária se desenvolva de forma adequada, segundo o sistema instituído pela CRFB/1988.

Logo, tanto o Congresso Nacional como as assembleias legislativas, as câmaras municipais e a Câmara Legislativa do DF são fontes de normas - no sentido que Tárek Moysés

472 ESTEVES, Maria do Rosário. Normas gerais de direito tributário. São Paulo: Max Limonad, 1997. p. 55-56.

473 FERRAZ JÚNIOR, Tércio Sampaio. Normas gerais e competência concorrente: uma exegese do art. 24 da Constituição Federal. Revista da Faculdade de Direito da Universidade de São Paulo, São Paulo, n. 90, p. 245-251, 1995. Disponível em: http://www.revistas.usp.br/rfdusp/article/view/67296/69906. Acesso em: 2 ago. 2016. p. 250.

474 ALMEIDA, Fernanda Dias Menezes de. Art. 24: Compete à União, aos Estados e ao Distrito Federal legislar concorrentemente sobre. In: CANOTILHO, J. J. Gomes et al (Coord. cient.); LEOCY, Léo Ferreira (Coord. exec.). Comentários à Constituição do Brasil. 1. ed. 6. tir. São Paulo: Saraiva, 2014. p. 751. 


\section{•- Contas dos governantes}

Moussallem ${ }^{475}$ atribui à expressão - aplicáveis ao controle externo da Administração Pública. Conquanto, ao legislarem sobre a matéria, estejam adstritos ao modelo de sistema de accountability financeira e orçamentária instituído pela CRFB/1988, sua produção legislativa é fundamental para a integração e o funcionamento daquele sistema.

Pelo exposto, os tribunais de contas e os gestores públicos, ao exercerem e se sujeitarem, respectivamente, a accountability financeira e orçamentária, convivem com normas veiculadas pela $\mathrm{CRFB} / 1988$, pelas leis nacionais introdutoras de normas gerais de direito financeiro, pelas constituições estaduais, pelas leis orgânicas municipais, pelas leis orgânicas dos tribunais de contas, federal, estaduais ou municipais e pelos seus regimentos internos, além das demais normas específicas, eventualmente editadas em âmbito local sobre a matéria. São essas normas que integram, preenchem, completam o sistema constitucional de accountability financeira e orçamentária da Administração Pública, de forma a atender às peculiaridades regionais e locais, sem descuidar de observar uma uniformidade mínima necessária ao seu bom funcionamento.

Dessa maneira, a atuação das cortes de controle externo é conformada a partir das competências que lhes são atribuídas diretamente pela CRFB/1988 - em geral, reproduzidas nas constituições estaduais e, no caso dos tribunais de contas de município, nas leis orgânicas municipais -, apresentadas na seção seguinte deste trabalho.

\subsection{COMPETÊNCIAS E FUNÇÕES DOS TRIBUNAIS DE CONTAS}

Os incisos do artigo 71 da CRFB/1988 enumeram as atuais ${ }^{476}$ competências dos tribunais de contas brasileiros ${ }^{477}$, como agentes de accountability horizontal em relação à gestão financeira e orçamentária da Administração Pública.

75 MOUSSALLEM, Tárek Moysés. Fontes do direito tributário. 2. ed. São Paulo: Noeses, 2006. p. 118.

476 A respeito da evolução do tribunal de contas nas constituiçôes brasileiras, cf. LAUBÉ, Vitor Rolf. Considerações acerca da conformação constitucional do tribunal de contas. Revista de Informação Legislativa, Brasília, v. 29, n. 113, p. 307-326, jan./mar. 1992. p. 311-313; A respeito de tentativas de mudança nas competências dos tribunais de contas durante a vigência da Constituição de 1946, cf. ALMEIDA, Fernando Bessa de. A fiscalização financeira e orçamentária na Constituição de 1967. Revista de Administração Pública, Rio de Janeiro, n. 1, p. 103-143, 1967. p. 138-139; e a respeito da participação da comunidade dos tribunais de contas no debate, junto à Assembleia Nacional Constituinte, para definir como seriam dispostas as competências dos tribunais de contas na CRFB/1988, cf. SOUZA, Luciano Brandão Alves de. A Constituição de 1988 e o Tribunal de Contas da União. Revista de Informação Legislativa, Brasília, v. 26, n. 102, p. 173-184, abr./jun. 1989. p. 174-175.

477 A respeito da organização geral e principais competências das ISC da Itália, da Bélgica, da França, da Inglaterra, de Portugal e da Espanha, cf. MEDAUAR, Odete. Controle da Administração Pública pelo tribunal de contas. Revista de Informação Legislativa, Brasília, v. 27, n. 108, p. 101-126, out./dez. 1990. p. 104-113; Para uma análise comparativa das ISC das Américas, de Portugal e da Espanha, cf. ARAUUJO, Marcos Valério de. Como controlar o Estado: reflexões e propostas sobre o controle externo nas Américas, Portugal e Espanha. Brasília: UNITEC, 1992; A respeito das ISC dos países membros da União Europeia e sobre a ISC da própria Uniāo Europeia, cf. UNITED KINGDOM. National Audit Office (NAO). State audit in the European Union. 3. ed. London: National Audit Office, 2005; sobre as ISC da Argentina, do Chile, da Bélgica, da Espanha, da França, da Itália, de Portugal, do Uruguai 
Vale dizer que, embora o caput do artigo 71 se refira especificamente ao TCU, por força do artigo 75 da CRFB/1988 - que dispõe que "As normas estabelecidas nesta seção aplicam-se, no que couber, à organização, composição e fiscalização dos Tribunais de Contas dos Estados e do Distrito Federal, bem como dos Tribunais e Conselhos de Contas dos Municípios”478 -, tais competências também são atribuídas às cortes de controle externo subnacionais. É que, conforme ensina Uadi Lammêgo Bulos $^{479}$ e decidiu em algumas oportunidades o STF ${ }^{480}$, o artigo 71 da CRFB/1988 pertence ao conjunto das normas cuja reprodução nas constituiçôes estaduais é obrigatória, também denominadas normas centrais federais. Desse modo, tendo instituído sistema constitucional de accountability financeira e orçamentária, a CRFB/1988 distribuiu competências não só ao TCU, mas a todas as cortes de contas brasileiras.

Da análise do artigo 71 da Constituição, verifica-se, com Maria Sylvia Zanella Di Pietro ${ }^{481}$, que o controle externo a cargo dos tribunais de contas foi significativamente ampliado. De acordo com Eduardo Lobo Botelho Gualazzi, “[...] nunca os Tribunais de Contas Brasileiros dispuseram de competências constitucionais tão amplas e incisivas, para desempenho de sua missão, inclusive com listagem taxativa de competências no texto constitucional"482.

Essa ampliação no rol de competências das cortes de contas não ocorre por acaso. Para Carlos Ayres Britto ${ }^{483}$, ela decorre do elevado prestígio que o legislador consti-

e da União Europeia, cf. CHADID, Ronaldo. A função social do Tribunal de Contas no Brasil. Belo Horizonte: Fórum, 2019. p. 142-162; A respeito da ISC venezuelana, cf. RODRIGUEZ GARCIA, Armando. Bases conceptuales del control de cuentas de la administracion y sus posibles distorsiones. Referencias al caso venezolano. In: RODRÍGUEZ-ARANA, Jaime; DELPIAZZO, Carlos; SILVA FILHO, João Antonio da; VALIM, Rafael; RODRÍGUEZ, María. Control administrativo de la actividad de la administración. v. 1. São Paulo: 2019. (XVIII Foro Iberoamericano de Derecho Administrativo). p. 244-248; A respeito das experiências institucionais francesa, norte-americana, argentina e chilena, cf. WILLEMAN, Marianna Montebello. A accountability democrática e o desenho institucional dos tribunais de contas no Brasil. 2. ed. Belo Horizonte: Fórum, 2020. p. 117-134.

478 BRASIL. Constituição (1988). Constituição da República Federativa do Brasil. Disponível em: http:// www.planalto.gov.br/ccivil_03/Constituicao/Constituicao.htm. Acesso em: 2 dez. 2019.

479 BULOS, Uadi Lammêgo. Curso de direito constitucional. 9. ed. São Paulo: Saraiva, 2015. p. 1242.

480 Cf. BRASIL. Supremo Tribunal Federal. Ação direta de inconstitucionalidade n. 849-8 Mato Grosso. Relator: Ministro Sepúlveda Pertence. Tribunal Pleno, Brasília, 11 de fevereiro de 1999. Diário da Justiça, Brasília, n. 76, 23 abr. 1999. Disponível em: http://redir.stf.jus.br/paginadorpub/paginador. jsp?docTP $=$ AC\&docID=266565. Acesso em: 1 fev. 2018; e BRASIL. Supremo Tribunal Federal. Ação direta de inconstitucionalidade n. 1.779-1 Pernambuco. Relator: Ministro Ilmar Galvão. Tribunal Pleno, Brasília, 1º de agosto de 2001. Diário da Justiça, Brasília, n. 166, 14 set. 2001. Disponível em: http:// redir.stf.jus.br/paginadorpub/paginador.jsp?docTP=AC\&docID=266757. Acesso em: 22 abr. 2017.

481 DI PIETRO, Maria Sylvia Zanella. Direito administrativo. 30. ed. São Paulo: Forense, 2017. p. 924.

${ }^{482}$ GUALAZZI, Eduardo Lobo Botelho. Regime jurídico dos tribunais de contas. São Paulo: Revista dos Tribunais, 1992. p. 173.

483 BRITTO, Carlos Ayres. O regime constitucional dos tribunais de contas. Revista Diálogo Jurídico, Salvador, v. 1, n. 9, p. 1-12, dez. 2001. Disponível em: http://www.direitopublico.com.br. Acesso em: 24 fev. 2017. p. 10. 


\section{-• Contas dos governantes}

tuinte conferiu ao controle externo da gestão financeira e orçamentária da Administração Pública, reflexo direto da influência da tradição republicana na democracia representativa brasileira. Certo é que, como observou André Janjácomo Rosilho, na Assembleia Nacional Constituinte de 1987 e 1988, os tribunais de contas, liderados pelo TCU, aproveitaram o momento que lhes era propício para "[...] advogar em prol da ampliação de suas próprias competências e do seu escopo de atuação" ${ }^{484}$.

$\mathrm{Na}$ doutrina, didaticamente, os autores agrupam e classificam tais competências em funções. Assim, por exemplo, no ordenamento constitucional anterior, Hely Lopes Meirelles dizia que tanto o TCU como os tribunais de contas dos estados e municípios detinham as seguintes atribuições: "[...] opinativas (a), verificadoras (b), assessoradoras (c, d, f), corretivas (e) e jurisdicionais administrativas ( $\mathrm{g}, \mathrm{h})\left[\ldots{ }^{\prime \prime 485}\right.$.

Para Maria Sylvia Zanella Di Pietro ${ }^{486}$, sob a égide da CRFB/1988 as cortes de contas exercem as funções de: fiscalização financeira, consulta, informação, julgamento, sancionatórias, corretivas e de ouvidoria. Para Eduardo Lobo Botelho Guala$\mathrm{zzi}^{487}$, as funçôes seriam a consultiva, a verificadora, a inspetiva, a fiscalizatória, a informativa, a coercitiva, a reformatória, a suspensiva e a declaratória. Carlos Ayres Britto as classifica em opinativa, judicante, consultiva e informativa, sancionadora e corretiva $^{488}$. Lucas Rocha Furtado ${ }^{489}$, por sua vez, organiza suas principais atribuições em: opinativa ou consultiva, de julgamento de contas, de registro, fiscalizadora, sancionadora e corretiva. Finalmente, Marcus Abraham ${ }^{490}$ enumera as funçôes fiscalizadora, opinativa, julgadora, sancionadora, corretiva, consultiva, informativa, ouvidora e normativa das cortes de controle externo.

Neste trabalho, porém, por opção, adota-se, com adaptação, a classificação de José Mauricio Conti ${ }^{491}$, que divide as funções dos tribunais de contas em nove, do

484 ROSILHO, André Janjácomo. Controle da administração pública pelo Tribunal de Contas da União. 2016. 358 f. Tese (Doutorado em Direito) - Departamento de Direito do Estado, Faculdade de Direito, Universidade de São Paulo, São Paulo, 2016. f. 77-78.

485 MEIRELLES, Hely Lopes. A administração pública e seus controles. Revista de Direito Administrativo, Rio de Janeiro, n. 114, p. 23-33, out./dez. 1973. p. 32.

486 DI PIETRO, Maria Sylvia Zanella. Direito administrativo. 30. ed. São Paulo: Forense, 2017. p. 924-925.

487 GUALAZZI, Eduardo Lobo Botelho. Regime jurídico dos tribunais de contas. São Paulo: Revista dos Tribunais, 1992. p. 193.

488 BRITTO, Carlos Ayres. O regime constitucional dos tribunais de contas. Revista Diálogo Jurídico, Salvador, v. 1, n. 9, p. 1-12, dez. 2001. Disponível em: http://www.direitopublico.com.br. Acesso em: 24 fev. 2017. p. 6.

489 FURTADO, Lucas Rocha. Curso de direito administrativo. 5. ed. Belo Horizonte: Fórum, 2016. p. 952-954.

490 ABRAHAM, Marcus. Curso de direito financeiro brasileiro. 3. ed. Rio de Janeiro: Forense, 2015. p. 318.

491 CONTI, José Mauricio. Direito financeiro na Constituição de 1988. São Paulo: Oliveira Mendes, 1998. p. 23-25. 
seguinte modo: fiscalizadora, consultiva, informativa, judicante, sancionadora, corretiva, normativa, ouvidoria e administrativa. A adaptação que aqui se faz à sua classificação é a inclusão da função reintegradora, que, por questões didáticas, é tratada, neste trabalho, em conjunto com a função sancionadora. Nas subseções seguintes, apresenta-se cada uma delas.

\subsubsection{Função administrativa}

Diferentemente do que ocorre em relação às demais funções, o exercício da função administrativa das cortes de contas não é, especificamente, o exercício de controle externo da Administração Pública. Isso não diminui a sua importância.

Como se depreende do conceito de Guillermo O’Donnell, apresentado na subseção 1.5 .2 (p. 62) deste trabalho, as agências de accountability horizontal devem não só ter o direito e o poder legal para a fiscalização financeira e orçamentária, como devem estar dispostas e dotadas de capacidade para realizar suas ações.

É, justamente, a função administrativa dos tribunais de contas que lhes garante a capacidade de realizar o controle externo da Administração Pública. Não fosse tal função, tais cortes não teriam a autonomia e a independência necessárias ao cumprimento de sua missão constitucional. Nesse sentido, na Declaração do México de 2007, a INTOSAI ${ }^{492}$ estabeleceu a autonomia financeira e administrativa, com a disponibilidade de recursos humanos, materiais e monetários adequados, como princípio de independência das ISC.

Segundo José Mauricio Conti ${ }^{493}$, a função administrativa das cortes de contas abrange toda a organização administrativa de sua secretaria, inclusive a proposição de criação, extinção e transformação de cargos e funções, e da fixação de suas remuneraçôes ao Poder Legislativo.

A existência de autonomia para o exercício da função administrativa dos tribunais de contas se funda na combinação entre os artigos 73, 75 e 96 da CRFB/1998. Conforme referidos artigos 73 e 75 , as cortes de controle externo têm quadro próprio de pessoal e exercem, "[...] no que couber, as atribuições previstas no art. 96”494

Assim, considerando o disposto no artigo 96 da CRFB/1988, compete privativamente aos tribunais de contas: (i) eleger seus órgãos diretivos; (ii) elaborar seus regimentos internos; (iii) organizar suas secretarias e serviços auxiliares; (iv) prover os

492 INTERNATIONAL ORGANIZATION OF SUPREME AUDIT INSTITUTIONS (INTOSAI). INTOSAI Principles. INTOSAI Core Principles. INTOSAI-P 10: Mexico declaration on SAI independence. Mexico City: INTOSAI, 2007. Disponível em: https://www.issai.org/professional-pronouncements/?n=10-99. Acesso em: 25 out. 2019. p. 10.

493 CONTI, José Mauricio. Direito financeiro na Constituição de 1988. São Paulo: Oliveira Mendes, 1998. p. 25.

494 BRASIL. Constituição (1988). Constituição da República Federativa do Brasil. Disponível em: http:// www.planalto.gov.br/ccivil_03/Constituicao/Constituicao.htm. Acesso em: 2 dez. 2019. 


\section{•. Contas dos governantes}

cargos de ministros, conselheiros e, por concurso público - exceto os cargos de provimento em comissão -, os cargos de seus substitutos, dos procuradores de contas e os demais cargos necessários à administração de sua secretaria e à execução da accountability financeira e orçamentária da Administração Pública; e (v) conceder licença, férias e outros afastamentos a seus membros e servidores. Além disso, cabe às cortes de contas propor ao Poder Legislativo, do ente ao qual pertence, a fixação da remuneração de seus membros, inclusive substitutos, e dos cargos vinculados às suas secretarias; e a criação e extinção de cargos e funções vinculados às suas secretarias.

Como destaca José Mauricio Conti - em lição voltada ao Poder Judiciário, mas aplicável às cortes de controle externo por força combinada dos artigos 73, 75 e 96 da CRFB/1988 -, a autonomia institucional envolve e exige "[...] autogoverno, autoadministração organizacional e financeira, e a autonomia funcional, com as garantias de independência da Magistratura" ${ }^{\text {"95 }}$. Nesse sentido, o STF ${ }^{496}$ reconhece o poder de autogoverno e a autonomia funcional, administrativa e financeira dos tribunais de contas brasileiros.

\subsubsection{Função de ouvidoria}

A função de ouvidoria é a prevista nos parágrafos $1^{\circ}$ e $2^{\circ}$ do artigo 74 da CRFB/1988, pelos quais as cortes de contas são competentes para receber denúncias de irregularidades ou ilegalidades que lhes sejam encaminhadas pelos responsáveis pelo controle interno ou por qualquer cidadão, partido político, associação ou sindicato.

495 CONTI, José Mauricio. A Lei de Diretrizes Orçamentárias e a autonomia financeira do Poder Judiciário. Revista Fórum de Direito Financeiro e Econômico - RFDFE, Belo Horizonte, v. 1, n. 1, p. 2737, mar./ago. 2012. p. 29; Em idêntico sentido, cf. CONTI, José Mauricio. A autonomia financeira do Poder Judiciário. 2. ed. São Paulo: Blucher, 2019. p. 59.

496 Cf. BRASIL. Supremo Tribunal Federal. Ação direta de inconstitucionalidade n. 1.994-5 Espírito Santo. Relator: Ministro Eros Grau. Tribunal Pleno, Brasília, 24 de maio de 2006. Diário da Justiça, Brasília, n. 173, 8 set. 2006. Disponível em: http://redir.stf.jus.br/paginadorpub/paginador.jsp?docTP=AC\&docID= 375300. Acesso em: 24 abr. 2017; BRASIL. Supremo Tribunal Federal. Ação direta de inconstitucionalidade n. 3.223 Santa Catarina. Relator: Ministro Dias Toffoli. Plenário, Brasília, 6 de novembro de 2014. Diário da Justiça Eletrônico, Brasília, n. 21, 2 fev. 2015. Disponível em: http://redir.stf.jus.br/paginadorpub/paginador.jsp?docTP=TP\&docID=7637724. Acesso em: 24 abr. 2017; BRASIL. Supremo Tribunal Federal. Medida cautelar na ação direta de inconstitucionalidade n. 4.643 Rio de Janeiro. Relator: Ministro Luiz Fux. Plenário, Brasília, 6 de novembro de 2014. Diário da Justiça Eletrônico, Brasília, n. 234, 28 nov. 2014. Disponível em: http://redir.stf.jus.br/paginadorpub/paginador.jsp?docTP=TP\&docID= 7342646. Acesso em: 24 abr. 2017; BRASIL. Supremo Tribunal Federal. Quarto agravo regimental no recurso extraordinário n. 285.302 São Paulo. Relator: Ministro Teori Zavaski. Segunda Turma, Brasília, 6 de outubro de 2015. Diário da Justiça Eletrônico, Brasília, n. 208, 19 out. 2015. Disponível em: http:// redir.stf.jus.br/paginadorpub/paginador.jsp?docTP=TP\&docID=9602593. Acesso em: 24 abr. 2017; e BRASIL. Supremo Tribunal Federal. Ação direta de inconstitucionalidade n. 4.418 Tocantins. Relator: Ministro Dias Toffoli. Plenário, Brasília, 15 de dezembro de 2016. Diário da Justiça Eletrônico, Brasília, n. 40,3 mar. 2017. Disponível em: http://redir.stf.jus.br/paginadorpub/paginador.jsp?docTP=TP\&docID= 12592854. Acesso em: 24 abr. 2017. 
Nas lições de Luciano Brandão Alves de Souza, a função de ouvidoria atribuída aos tribunais de contas pela CRFB/1988 “[...] tem inegável sentido democrático e configura inestimável conquista do cidadão, a quem se defere ação presente e participativa no controle dos dinheiros públicos"497. Sua inclusão na Constituição de 1988 é resultado da influência conjunta das tradições democrática e republicana na democracia representativa brasileira.

Segundo Eduardo Lobo Botelho Gualazzi, os parágrafos do artigo 74, combinados com as demais competências atribuídas às cortes de controle externo brasileiras, as colocam na condição de verdadeiras Ombudsman, possibilitando "[...] aos administrados realizar controle administrativo em relação às lacunas omissivas ou comissivas, às zonas cinzentas e a certos abusos e distorções do poder discricionário no âmbito interno da Administração Pública"498. Assim, as informaçóes prestadas pelas unidades de controle interno e as denúncias apresentadas por cidadão, partido político, associação ou sindicato levam ao conhecimento dos tribunais de contas supostas irregularidades ou ilegalidades cometidas na gestão financeira e orçamentária da Administração Pública, impulsionando o processo de controle externo.

Deve ficar claro que as cortes de contas, ao empreenderem fiscalizações impulsionadas por terceiros - mediante denúncia, representação ou comunicação de irregularidades ou ilegalidades -, não ficam adstritas aos termos por eles trazidos ao processo. É nesse sentido a jurisprudência pacífica do TCU ${ }^{499}$.

Desse modo, como não se submetem ao princípio na inércia jurisdicional - já que, conforme exposto na subseção 2.6 .7 (p. 146) deste trabalho, podem realizar fiscalizações por iniciativa própria -, podem estender o objeto da fiscalização conforme entenderem tecnicamente necessário, inclusive para abarcar irregularidade ou ilegalidades não aventadas originalmente e alcançar agentes públicos diversos daqueles arrolados na peça inicial.

\subsubsection{Função normativa}

Como estabelece o artigo $3^{\circ}$ de sua Lei Orgânica, ao TCU, "[...] no âmbito de sua competência e jurisdição, assiste o poder regulamentar, podendo [...] expedir atos

497 SOUZA, Luciano Brandão Alves de. A Constituição de 1988 e o Tribunal de Contas da União. Revista de Informação Legislativa, Brasília, v. 26, n. 102, p. 173-184, abr./jun. 1989. p. 182.

498 GUALAZZI, Eduardo Lobo Botelho. Controle administrativo e "Ombudsman". Revista da Faculdade de Direito da Universidade de São Paulo, São Paulo, n. 86, p. 144-163, 1991. p. 149; 163.

499 Cf. BRASIL. Tribunal de Contas da União. Acórdão n. 2.522/2013-Plenário. Relator: Ministro José Jorge. Plenário, Brasília, 18 de setembro de 2013. Boletim de Jurisprudência, Brasília, n. 9, 30 set. 2013. Disponível em: https://contas.tcu.gov.br/pesquisaJurisprudencia/\#/pesquisa/acordao-completo. Acesso em: 24 abr. 2017; e BRASIL. Tribunal de Contas da União. Acórdão n. 277/2014-Plenário. Relator: Ministro Raimundo Carreiro. Plenário, Brasília, 12 de fevereiro de 2014. Boletim de Jurisprudência, Brasília, n. 25, 24 fev. 2014. Disponível em: https://contas.tcu.gov.br/pesquisaJurisprudencia/\#/pesquisa/acordao-completo. Acesso em: 24 abr. 2017. 


\section{-. Contas dos governantes}

e instruções normativas sobre matéria de suas atribuições e sobre a organização dos processos que lhe devam ser submetidos [...]" ${ }^{500}$. Além dela, diversas leis orgânicas das cortes de controle externo subnacionais possuem dispositivo idêntico ou semelhante, com referência expressa ao "poder regulamentar".

Contudo, Luís Roberto Barroso destaca que “[...] não é controvertido, em doutrina, que o poder regulamentar é privativo do Chefe do Executivo" ${ }^{501}$. Desse modo, segundo ele, se entendida no seu sentido mais óbvio, a expressão "poder regulamentar" atribuída por lei a tais tribunais de contas seria inconstitucional, uma vez que, compulsando as competências previstas no artigo 71 da CRFB/1988, não há alusão a competência regulamentar das cortes de contas ${ }^{502}$.

Por outro lado, como ensina Luís Roberto Barroso, "[...] é possível admitir a validade da expressão 'poder regulamentar', desde que se entenda que o legislador quis referir-se a uma competência administrativa normativa" ${ }^{503}$. Como explica, "[...] parece aceitável reconhecer-se ao Tribunal de Contas competência para editar atos normativos administrativos, como seu Regimento Interno, ou para baixar uma Resolução ou outros atos internos" 504 .

Efetivamente, verificada a parte final do artigo $3^{\circ}$ da Lei Orgânica do TCU, a consequência do denominado "poder regulamentar" seria exatamente a possibilidade de expedição de atos normativos administrativos sobre questôes referentes à suas atribuições e a respeito da organização dos processos que tramitam em seu âmbito, bem como preconizam as liçôes de Luís Roberto Barroso. Nesse sentido, José Mauricio Conti ensina que a função normativa se refere à “[...] expedição de atos e instruções normativas sobre matérias de sua competência e sobre a organização dos processos que lhe devam ser submetidos" 505 .

500 BRASIL. Lei n. 8.443, de 16 de julho de 1992. Dispõe sobre a Lei Orgânica do Tribunal de Contas da União e dá outras providências. Diário Oficial da União, Brasília, a. CXXX, n. 136, Seção 1, p. 9.4499.456, 17 jul. 1992. Disponível em: http://www.planalto.gov.br/ccivil_03/leis/L8443.htm. Acesso em: 25 out. 2019.

501 BARROSO, Luís Roberto. Tribunais de contas: algumas incompetências. Revista de Direito Administrativo, Rio de Janeiro, v. 203, p. 131-140, jan./mar. 1996. p. 135.

502 É interessante ter em conta que um dos dispositivos propostos à Assembleia Nacional Constituinte de 1987 e 1988, pelos tribunais de contas, não contemplado na redação da CRFB/1988, dar-lhes-ia competência para expedir normas para o exercício do controle externo, cf. ROSILHO, André Janjácomo. Controle da administração pública pelo Tribunal de Contas da União. 2016. 358 f. Tese (Doutorado em Direito) - Departamento de Direito do Estado, Faculdade de Direito, Universidade de São Paulo, São Paulo, 2016. f. 122-123.

503 BARROSO, Luís Roberto. Tribunais de contas: algumas incompetências. Revista de Direito Administrativo, Rio de Janeiro, v. 203, p. 131-140, jan./mar. 1996. p. 136.

504 BARROSO, Luís Roberto. Tribunais de contas: algumas incompetências. Revista de Direito Administrativo, Rio de Janeiro, v. 203, p. 131-140, jan./mar. 1996. p. 136.

505 CONTI, José Mauricio. Direito financeiro na Constituição de 1988. São Paulo: Oliveira Mendes, 1998. p. 25. 
Dessa maneira, como explica André Janjácomo Rosilho ${ }^{506}$, os tribunais de contas não podem criar para si competências ou atribuições, nem ampliar ou restringir os limites de sua atuação. Segundo ele, ao disciplinar aspectos procedimentais ligados às suas atividades, são autorizados, até mesmo, a criar obrigações a outros atores, desde que sejam necessárias, proporcionais e estritamente relacionadas a aspectos procedimentais do exercício das competências que lhes foram atribuídas pela CRFB/1988. Se, contudo, escapam desses limites, sua atuação é inconstitucional ${ }^{507}$.

Quando precisarem editar atos normativos que criem obrigações para outros atores, as cortes de contas devem observar o novel artigo 29 da LINDB. Assim, é importante que a edição seja precedida de consulta pública, para manifestação dos eventuais interessados, como forma de aperfeiçoar o conteúdo do ato a ser emitido ${ }^{508}$.

Portanto, no exercício de sua função normativa, os tribunais de contas devem se limitar à edição de atos normativos administrativos, como exemplo, seu regimento interno e resoluçôes que organizem a forma como devem se desenvolver os processos no seu âmbito de atividade e a forma como devem receber documentos e informaçóes. Exorbitam à função normativa que lhes é concedida quando, desavisadamente, produzem atos normativos que geram direitos e obrigações para terceiros que não sejam, absolutamente, necessárias, proporcionais e estritamente relacionadas a aspectos procedimentais do exercício das competências que lhes foram atribuídas pela CRFB/1988.

\subsubsection{Função corretiva}

Nos termos do artigo 71, inciso IX, da CRFB/1988, combinado com seu artigo 75, compete aos tribunais de contas "assinar prazo para que o órgão ou entidade adote as

${ }^{506}$ ROSILHO, André Janjácomo. Controle da administraçáo pública pelo Tribunal de Contas da União. 2016. 358 f. Tese (Doutorado em Direito) - Departamento de Direito do Estado, Faculdade de Direito, Universidade de São Paulo, São Paulo, 2016. f. 125-126.

507 O STF, em caráter cautelar, suspendeu os efeitos do artigo 10, inciso II, da Deliberação n. 45, de 9 de novembro de 1982, do Tribunal de Contas do Estado do Rio de Janeiro (TCE-RJ) - que aprovou seu Regimento Interno anterior, não mais em vigor - que atribuía caráter normativo às soluções de consulta encaminhadas à corte de contas, cf. RIO DE JANEIRO (Estado). Tribunal de Contas do Estado. Deliberação n. 45, de 9 de dezembro de 1982. Aprova o Regimento Interno do Tribunal de Contas do Estado do Rio de Janeiro. Diário Oficial do Estado do Rio de Janeiro, Rio de Janeiro, 29 nov. 1982. Disponível em: http://www.tce.rj.gov.br/web/guest/deliberacao-por-assunto. Acesso em: 26 abr. 2017; e BRASIL. Supremo Tribunal Federal. Medida cautelar na ação direta de inconstitucionalidade n. 8285 Rio de Janeiro. Relator: Ministro Marco Aurélio. Tribunal Pleno, Brasília, 27 de maio de 1993. Diário da Justiça, Brasília, 1 jul. 1993. Disponível em: http://redir.stf.jus.br/paginadorpub/paginador. jsp? docTP=AC\&docID=346630. Acesso em: 26 abr. 2017.

508 Embora o texto aprovado diga que os atos administrativos normativos "poderão" ser precedidos de consulta pública, Vera Monteiro defende que a sua realização é um dever, cuja inobservância torna o ato inválido, cf. MONTEIRO, Vera. Art. 29 da LINDB: regime jurídico da consulta pública. Revista de Direito Administrativo, Rio de Janeiro, Edição Especial: Direito Público na Lei de Introdução às Normas de Direito Brasileiro - LINDB (Lei n. 13.655/2018). p. 225-242, nov. 2018. DOI: 10.12660/ rda.v0.2018.77656. p. 232-239. 


\section{•. Contas dos governantes}

providências necessárias ao exato cumprimento da lei, se verificada ilegalidade" ${ }^{509}$. Trata o dispositivo constitucional da função corretiva atribuída às cortes de controle externo.

Inicialmente, cabe esclarecer que a função corretiva das cortes de contas é autônoma. Embora Heloísa Helena Antonacio M. Godinho ${ }^{510}$ vincule a atividade corretiva das cortes de controle externo ao exercício de sua função judicante - como se somente pudesse ser exercida no âmbito dos processos em que são julgadas contas -, na realidade, não existe esse vínculo.

É verdade que a função corretiva dificilmente é exercida isoladamente. Contudo, ela não opera somente nos processos de julgamento de contas, mas também nas diversas espécies de processos de fiscalização e naqueles de apreciação das contas prestadas por chefes de Poder Executivo, quando os tribunais de contas exercem, respectivamente, as funções fiscalizadora e consultiva, tratadas nas subseções 2.6.7 (p. 146) e 2.6.9 (p. 162) deste trabalho. Como está fundada em competências específicas, previstas em incisos próprios do artigo 71 da CRFB/1988, não há razão para entender que a função corretiva depende de quaisquer das outras competências.

No exercício da função corretiva, as cortes de contas, ao verificarem a ocorrência de irregularidades e ilegalidades - não qualquer hipótese de ilegalidade, mas apenas aquelas relativas à gestão financeira e orçamentária da Administração Pública ${ }^{511}$; além disso, perceba-se que não se limita a ilegalidades, abrangendo também falhas ou impropriedades $^{512}$-, podem determinar, aos agentes públicos responsáveis, a adoção das providências necessárias a corrigir a situação inapropriada, ou recomendar medidas com a finalidade de aprimorar a gestão e prevenir a ocorrência de outras irregularidades. É farta, nesse sentido, a jurisprudência do TCU ${ }^{513}$.

509 BRASIL. Constituição (1988). Constituição da República Federativa do Brasil. Disponível em: http:// www.planalto.gov.br/ccivil_03/Constituicao/Constituicao.htm. Acesso em: 2 dez. 2019.

510 GODINHO, Heloísa Helena Antonacio M. Ideias no lugar: as decisões condenatórias proferidas pelos tribunais de contas. SARQUIS, Alexandre Manir Figueiredo. Citação e revelia no processo de contas. In: LIMA, Luiz Henrique; SARQUIS, Alexandre Manir Figueiredo (Coord.). Processos de controle externo: estudos de ministros e conselheiros substitutos dos tribunais de contas. Belo Horizonte: Fórum, 2019. p. 223-224.

511 Cf. BRASIL. Tribunal de Contas da União. Acórdão n. 111/2010-Plenário. Relator: Ministro Aroldo Cedraz. Plenário, Brasília, 3 de fevereiro de 2010. Disponível em: https://contas.tcu.gov.br/pesquisaJurisprudencia/\#/pesquisa/acordao-completo. Acesso em: 24 abr. 2017.

512 Cf. BRASIL. Tribunal de Contas da União. Acórdão n. 906/2015-Plenário. Relator: Ministro Bruno Dantas. Plenário, Brasília, 22 de abril de 2015. Boletim de Jurisprudência, Brasília, n. 79, 11 maio 2015. Disponível em: https://contas.tcu.gov.br/pesquisaJurisprudencia/\#/pesquisa/acordao-completo. Acesso em: 24 abr. 2017.

513 Cf. BRASIL. Tribunal de Contas da União. Acórdão n. 2.689/2009-Segunda Câmara. Relator: Ministro Raimundo Carreiro. Segunda Câmara, Brasília, 26 de maio de 2009. Disponível em: https:// contas.tcu.gov.br/pesquisaJurisprudencia/\#/pesquisa/acordao-completo. Acesso em: 24 abr. 2017; BRASIL. Tribunal de Contas da União. Acórdão n. 859/2010-Plenário. Relator: Ministro Augusto Nardes. Plenário, Brasília, 28 de abril de 2010. Disponível em: https://contas.tcu.gov.br/pesquisaJurisprudencia/\#/pesquisa/acordao-completo. Acesso em: 24 abr. 2017; e BRASIL. Tribunal de Contas da 
As determinações proferidas pelas cortes de contas são de cumprimento obrigatório e, conforme tem decidido o TCU ${ }^{514}$, não estão sujeitas a juízo de conveniência e oportunidade dos gestores públicos. Caso não se conformem com a decisão, podem atacá-la mediante a interposição dos recursos previstos no ordenamento relativo à corte que a proferiu ou a impugnar perante o Poder Judiciário. O descumprimento das determinações emitidas pelos tribunais de contas, exceto nas hipóteses em que tenham sido suspensas ou cassadas, pode acarretar sanções aos responsáveis.

Ao expedirem recomendações ou determinações, os tribunais de contas, especialmente em razão do artigo 20, caput e parágrafo único, da LINDB, devem tanto demonstrar a sua necessidade e adequação como avaliar a sua viabilidade e considerar as suas consequências práticas. Marçal Justen Filho ${ }^{515}$ adverte que a demonstração da necessidade e da adequação exige a expressa avaliação das diversas alternativas cabíveis.

Deve-se ter em mente que não compete aos tribunais de contas “[...] estabelecer as ações de caráter operacional que devem ser implementadas pelas unidades gestoras para dar[-lhes] cumprimento" ${ }^{16}$, mas estipular os resultados a serem alcançados. Nesse sentido, corretamente, ao invés de definir quais ações devem ser tomadas, as cortes de controle externo, muitas vezes, têm determinado ao gestor que elabore e apresente, em prazo determinado, um plano de ação prevendo as ações que a Administração Pública adotará, com cronograma, para corrigir as irregularidades e ilegalidades encontradas ou prevenir ou mitigar riscos identificados.

Observe-se que, ainda no exercício da função corretiva, caso a determinação de tribunal de contas, visando à correção de irregularidade ou ilegalidade, não seja atendida, ele, por força do inciso X do artigo 71 da CRFB/1988, tem competência para sustar o ato irregular ou ilegal. Nesse caso, deve comunicar a decisão ao parlamento respectivo - caso o ato seja da Administração Pública municipal, à câmara municipal;

União. Acórdão n. 953/2012-Plenário. Relator: Ministro Weder de Oliveira. Plenário, Brasília, 25 de abril de 2012. Disponível em: https:/contas.tcu.gov.br/pesquisaJurisprudencia/\#/pesquisa/acordao-completo. Acesso em: 24 abr. 2017.

514 Cf. BRASIL. Tribunal de Contas da União. Acórdão n. 4.428/2014-Primeira Câmara. Relator: Ministro Benjamin Zymler. Plenário, Brasília, 19 de agosto de 2014. Boletim de Jurisprudência, Brasília, n. 51, 1 set. 2014. Disponível em: https://contas.tcu.gov.br/pesquisaJurisprudencia/\#/pesquisa/acordao-completo. Acesso em: 24 abr. 2017; e BRASIL. Tribunal de Contas da União. Acórdão n. 1.827/2016-Plenário. Relator: Ministro Marcos Bemquerer. Plenário, Brasília, 13 de julho de 2016. Disponível em: https://contas.tcu.gov.br/pesquisaJurisprudencia/\#/pesquisa/acordao-completo. Acesso em: 24 abr. 2017.

515 JUSTEN FILHO, Marçal. Art. 20 da LINDB: dever de transparência, concretude e proporcionalidade nas decisões públicas. Revista de Direito Administrativo, Rio de Janeiro, Edição Especial: Direito Público na Lei de Introdução às Normas de Direito Brasileiro - LINDB (Lei n. 13.655/2018). p. 13-41, nov. 2018. DOI: 10.12660/rda.v0.2018.77648. p. 32-33.

516 Cf. BRASIL. Tribunal de Contas da União. Acórdão n. 228/2017-Plenário. Relator: Ministro Vital do Rêgo. Plenário, Brasília, 15 de fevereiro de 2017. Disponível em: https://contas.tcu.gov.br/pesquisaJurisprudencia/\#/pesquisa/acordao-completo. Acesso em: 24 abr. 2017. 


\section{•. Contas dos governantes}

caso seja da Administração estadual, à assembleia legislativa; caso seja da União, ao Congresso.

Como defende Luís Roberto Barroso ${ }^{517}$, a competência dos tribunais de contas é para sustar o ato, não o invalidar. Outrossim, conforme Maria Sylvia Zanella Di Pietro, 'Há que se observar que 'sustar' não significa invalidar. Nem o Tribunal de Contas, nem o Congresso Nacional podem tirar do mundo jurídico um ato ou contrato praticado pela Administração [...]" ${ }^{\text {"18 }}$.

Da mesma forma que lhes é exigido na expedição de recomendações ou determinações, as decisões de sustação de ato irregular ou ilegal devem demonstrar a sua necessidade e adequação, avaliar a sua viabilidade e considerar as suas consequências práticas, como estabelece o artigo 20, caput e parágrafo único, da LINDB. A sustação, também, exige, por força do artigo 21, caput e parágrafo único, da LINDB, que as cortes de contas indiquem expressamente suas consequências jurídicas e administrativas e, quando for o caso, as condiçôes para que a regularização seja proporcional, equânime e não prejudique os interesses gerais, nem imponha ônus ou perdas anormais ou excessivas aos atingidos.

Portanto, na sustação se exige, como explica Pericles Ferreira de Almeida, "[...] a construção de uma ordem completa, evitando a decisão indireta ou implícita sobre aspectos imbricados à invalidação" ${ }^{19}$. É claro que não se exige deles a indicação de todas as consequências jurídicas e administrativas, mas daquelas que sejam economicamente, politicamente, administrativamente ou socialmente mais importantes, conforme José Vicente Santos de Mendonça ${ }^{520}$.

Inclusive nas situações em que, para sanear a irregularidade ou ilegalidade, seja necessária a anulação ou sustação de um contrato, os tribunais de contas detêm competência para determinar à Administração Pública que tome as providências para a anulação ou suspensão, conforme jurisprudência do TCU e do STF ${ }^{521}$. Nesses casos,

517 BARROSO, Luís Roberto. Tribunais de contas: algumas incompetências. Revista de Direito Administrativo, Rio de Janeiro, v. 203, p. 131-140, jan./mar. 1996. p. 139.

518 DI PIETRO, Maria Sylvia Zanella. O papel dos tribunais de contas no controle dos contratos administrativos. Interesse Público - IP, Belo Horizonte, v. 15, n. 82, p. 15-48, nov./dez. 2013. p. 18-19.

519 ALMEIDA, Pericles Ferreira de. Consideraçōes sobre a nova Lei de Introdução às Normas do Direito Brasileiro (Lei n. 13.665/2018). Revista de Direito Público da Economia - RDPE, Belo Horizonte, a. 16, n. 64, p. 147-174, out./dez. 2018. p. 151.

520 MENDONÇA, José Vicente Santos de. Art. 21 da LINDB: Indicando consequências e regularizando atos e negócios. Revista de Direito Administrativo, Rio de Janeiro, Edição Especial: Direito Público na Lei de Introdução às Normas de Direito Brasileiro - LINDB (Lei n. 13.655/2018). p. 43-61, nov. 2018. DOI: $10.12660 /$ rda.v0.2018.77649. p. 50.

521 Cf. BRASIL. Tribunal de Contas da União. Acórdão n. 2.105/2008-Plenário. Relator: Ministro Ubiratan Aguiar. Plenário, Brasília, 24 de setembro de 2008. Disponível em: https://contas.tcu.gov.br/ pesquisaJurisprudencia/\#/pesquisa/acordao-completo. Acesso em: 24 abr. 2017; BRASIL. Tribunal de Contas da União. Acórdão n. 2.343/2009-Plenário. Relator: Ministro Valmir Campelo. Plenário, Brasília, 7 de outubro de 2009. Disponível em: https://contas.tcu.gov.br/pesquisajurisprudencia/\#/pes- 
contudo, na hipótese de não serem atendidos pela Administração, devem comunicar a situação ao Legislativo, que é competente para o ato de sustação, por força do $₫ 1^{\circ}$ do artigo 71 da CRFB/1988. O parlamento, se acolher as razões apresentadas pela corte de contas, deve sustar o contrato e solicitar ao Poder Executivo as medidas cabíveis, conforme o final do referido parágrafo.

De acordo com o artigo 71, $\$ 2^{\circ}$, da CRFB/1988, "Se o Congresso Nacional ou o Poder Executivo, no prazo de noventa dias, não efetivar as medidas previstas no parágrafo anterior, o Tribunal decidirá a respeito" ${ }^{22}$. Nesses casos, deve-se dizer, a expressão "decidirá a respeito" permite grande celeuma doutrinária sobre se a omissão parlamentar transfere aos tribunais de contas a competência para sustar o contrato examinado ou se lhes resta declarar a ilegalidade e promover a responsabilização dos agentes públicos envolvidos ${ }^{523}$.

É, também, no exercício de sua função corretiva, que as cortes de controle externo adotam medidas cautelares com a finalidade de prevenir danos ao erário e garantir

quisa/acordao-completo. Acesso em: 24 abr. 2017; e BRASIL. Supremo Tribunal Federal. Mandado de segurança n. 23.550 Distrito Federal. Relator: Ministro Marco Aurélio. Plenário, Brasília, 4 de abril de 2001. Diário da Justiça, Brasília, n. 198, 31 out. 2001. Disponível em: http://redir.stf.jus.br/paginadorpub/paginador.jsp?docTP=AC\&docID=85979. Acesso em: 24 abr. 2017.

522 BRASIL. Constituição (1988). Constituição da República Federativa do Brasil. Disponível em: http:// www.planalto.gov.br/ccivil_03/Constituicao/Constituicao.htm. Acesso em: 2 dez. 2019.

523 A respeito da competência dos tribunais de contas, nas hipóteses em que o Poder Legislativo não se pronunciar sobre a sustação de contrato recomendada, cf. LAUBÉ, Vitor Rolf. Considerações acerca da conformação constitucional do tribunal de contas. Revista de Informação Legislativa, Brasília, v. 29, n. 113, p. 307-326, jan./mar. 1992. p. 315; BARROSO, Luís Roberto. Tribunais de contas: algumas incompetências. Revista de Direito Administrativo, Rio de Janeiro, v. 203, p. 131-140, jan./mar. 1996. p. 139; GRAU, Eros Roberto. Tribunal de Contas - Decisão - Eficácia (parecer). Revista de Direito Administrativo, Rio de Janeiro, v. 210, p. 351-356, out./dez. 1997. p. 355; FERNANDES, Jorge Ulisses Jacoby. Sustação de contratos pelos tribunais de contas. Fórum de Contratação e Gestão Pública - FCGP, Belo Horizonte, v. 1, n. 12, p. 1431-1434, dez. 2002. Disponível em: http://bidforum.com.br/bidBiblioteca_periodico_print.aspx?i=7595\&p=2. Acesso em: 25 abr. 2017. p. 3 (Versão digital); FERNANDES, Jorge Ulisses Jacoby. A ação dos tribunais de contas sobre os contratos. Fórum Administrativo - FA, Belo Horizonte, v. 4, n. 38, abr. 2004. Disponível em: http://www.bidforum. com.br/PDI0006.aspx?pdiCntd=4849. Acesso em: 25 abr. 2017. p. 6; FERNANDES, Jorge Ulisses Jacoby. Controle das licitaçôes pelo tribunal de contas. Fórum Administrativo - FA, Belo Horizonte, v. 5, n. 50, abr. 2005. Disponível em: http://www.bidforum.com.br/PDI0006.aspx?pdiCntd=6329. Acesso em: 25 abr. 2017. p. 10; MOREIRA, Egon Bockmann. Notas sobre os sistemas de controle dos atos e contratos administrativos. Fórum Administrativo - FA, Belo Horizonte, v. 5, n. 55, set. 2005. Disponível em: http://www.bidforum.com.br/bid/PDI0006.aspx?pdiCntd=30856. Acesso em: 25 abr. 2017. p. 9; SUNDFELD, Carlos Ari; CÂMARA, Jacintho Arruda. Controle das contratações públicas pelos tribunais de contas. Revista de Direito Administrativo, Belo Horizonte, n. 257, p. 111-144, maio/ago. 2011. p. 141-143; DI PIETRO, Maria Sylvia Zanella. O papel dos tribunais de contas no controle dos contratos administrativos. Interesse Público - IP, Belo Horizonte, v. 15, n. 82, p. 15-48, nov./dez. 2013. p. 23-24; ROSILHO, André Janjácomo. Controle da administração pública pelo Tribunal de Contas da Uniáo. 2016. 358 f. Tese (Doutorado em Direito) - Departamento de Direito do Estado, Faculdade de Direito, Universidade de São Paulo, São Paulo, 2016. f. 73-74; e WILLEMAN, Marianna Montebello. A accountability democrática e o desenho institucional dos tribunais de contas no Brasil. 2. ed. Belo Horizonte: Fórum, 2020. p. 260-265. 


\section{•. Contas dos governantes}

a efetividade de suas decisões, conforme ensina Valdecir Fernandes Pascoal ${ }^{524}$. O poder geral de cautela é reconhecido pela doutrina e pelo STF, como mostram Rachel Campos Pereira de Carvalho e Henrique de Paula Kleinsorge ${ }^{525}$, Marianna Montello Willeman ${ }^{526}$ e Romano Scapin ${ }^{527}$.

O que é dito acima, nesta subseção, sobre a necessidade de observância dos artigos 20 e 21 da LINDB, para a expedição de recomendações e determinações e para as decisões de sustação de ato irregular ou ilegal, é válido, também, para as cautelares. Desse modo, ao decidirem adotar medida cautelar, as cortes de contas devem demonstrar a sua necessidade e adequação, avaliar a sua viabilidade, considerar as suas consequências práticas e indicar expressamente suas consequências jurídicas e administrativas e, quando for o caso, as condiçōes para que a regularização seja proporcional, equânime e não prejudique os interesses gerais, nem imponha ônus ou perdas anormais ou excessivas aos atingidos.

Pelo exposto, a função corretiva dos tribunais de contas é independente de qualquer de suas outras funçóes e abrange a sua competência para expedir recomendaçóes e determinações - com o objetivo de aperfeiçoar a gestão, prevenir a ocorrência de irregularidades e ilegalidades ou as corrigir -, sustar atos irregulares e ilegais - nas hipóteses em que a Administração não atenda a determinação da corte - e adotar medidas cautelares - com a finalidade de prevenir danos ao erário e garantir a efetividade de suas decisóes. Em seu exercício, devem observar sempre os artigos 20 e 21 da LINDB.

\subsubsection{Funções sancionadora e reintegradora}

A função sancionadora encontra guarida no artigo 71, inciso VIII, da CRFB/1988, segundo o qual compete aos tribunais de contas "aplicar aos responsáveis, em caso de ilegalidade de despesa ou irregularidade de contas, as sanções previstas em lei, que estabelecerá, entre outras cominaçôes, multa proporcional ao dano causado ao erário" 528 .

Tendo em conta o princípio da legalidade, o legislador constituinte, ao elaborar o dispositivo, foi claro ao limitar as sanções que podem ser aplicadas pelas cortes de controle externo àquelas previstas em lei. Em consequência, como salienta Márcia

PASCOAL, Valdecir Fernandes. O poder cautelar dos tribunais de contas. Revista do Tribunal de Contas da União, Brasília, n. 115, p. 103-118, maio/ago. 2009. p. 107.

525 CARVALHO, Rachel Campos Pereira de; KLEINSORGE, Henrique de Paula. A cautelaridade nos tribunais de contas. Revista do Tribunal de Contas do Estado de Minas Gerais, Belo Horizonte, a. XXX, v. 83, n. 2, p. 53-68, abr./jun. 2012. p. 61-66.

526 WILLEMAN, Marianna Montebello. A accountability democrática e o desenho institucional dos tribunais de contas no Brasil. 2. ed. Belo Horizonte: Fórum, 2020. p. 265-266.

527 SCAPIN, Romano. A expedição de provimentos provisórios pelos tribunais de contas: das "medidas cautelares” à técnica antecipatória no controle externo brasileiro. Belo Horizonte: Fórum, 2019. p. 131-163.

${ }^{528}$ BRASIL. Constituição (1988). Constituição da República Federativa do Brasil. Disponível em: http:// www.planalto.gov.br/ccivil_03/Constituicao/Constituicao.htm. Acesso em: 2 dez. 2019. 
Pelegrini ${ }^{52}$, as cortes de contas, no exercício de sua função normativa, discutida na subseção 2.6.3 (p. 133) deste trabalho, não podem prever sanções diversas, nem diferentes hipóteses de aplicação, daquelas prescritas em dispositivo legal.

Desse modo, tomando em consideração as fontes normativas do sistema de accountability financeira e orçamentária da Administração Pública, enumeradas na subseção 2.5.4 (p. 121) deste trabalho, percebe-se que as sanções podem ser previstas na própria CRFB/1988, em leis nacionais, nas constituições estaduais, nas leis orgânicas municipais e nas leis orgânicas dos tribunais de contas, em todas as esferas federativas.

De fato, como se observa no seu transcrito artigo 71, inciso VIII, a própria CRFB/1988 previu uma sanção a ser aplicada pelas cortes de controle externo, qual seja, a multa proporcional ao dano causado ao erário. Dentre os entes subnacionais que possuem cortes de contas próprias, a grande maioria - as exceções são os estados de Mato Grosso, Roraima e Rio Grande do Sul e o município de São Paulo - reproduz tal sanção em suas constituições ou leis orgânicas, conforme o caso.

A multa por infração administrativa contra as leis de finanças públicas, tipificada no artigo $5^{\circ}$ da Lei n. 10.028, de 19 de outubro de 2000, é exemplo de sanção, a ser aplicada pelas cortes de controle externo, prevista em lei nacional.

Nas leis orgânicas dos tribunais de contas - vide, por exemplo, os artigos 46, 57, 58 e 60 da Lei Orgânica do TCU -, também são previstas sanções a serem por eles aplicadas. Além da repetição da multa proporcional ao dano causado ao erário, é o caso da: (i) multa, com valor limitado, aos responsáveis por contas julgadas irregulares, por ato praticado com grave violação às normas, por ato de gestão de que resulte injustificado dano ao erário, pelo não atendimento a decisão da respectiva corte de contas ou pela reincidência no descumprimento de suas determinaçôes; (ii) inabilitação do responsável para o exercício de cargo em comissão ou função de confiança no âmbito da Administração Pública; e (iii) declaração de inidoneidade do licitante fraudador para participar de licitação no âmbito do ente ao qual pertencer a corte de controle externo.

Além das sançôes, os tribunais de contas podem imputar débito aos agentes públicos, conforme prevê o artigo $71, \$ 3^{\circ}$, da CRFB/1988. É o que se denomina sua função reintegradora.

A doutrina de direito financeiro, brasileira e estrangeira ${ }^{530}$, trata, conjuntamente, a imputação de débito e a aplicação de multas, pelas cortes de controle externo, como

529 PELEGRINI, Márcia. A competência sancionatória do tribunal de contas no exercício da função controladora: contornos constitucionais. 2008. $331 \mathrm{f}$. Tese (Doutorado em Direito) - Departamento de Pós-Graduação em Direito, Pontifícia Universidade Católica de São Paulo, São Paulo, 2008. f. 123.

530 A respeito da responsabilidade financeira na Bélgica, na Espanha, na França, na Itália e em Portugal, cf. GOMES, Emerson Cesar da Silva. Responsabilidade financeira: uma teoria sobre a responsabilidade no âmbito dos tribunais de contas. 2009. 379 f. Dissertação (Mestrado em Direito) - Departamento de Direito Econômico, Financeiro e Tributário, Faculdade de Direito, Universidade de São Paulo, São Paulo, 2009. f. 53-104. 


\section{-• Contas dos governantes}

atribuição de responsabilidade financeira, definida por Emerson Cesar da Silva Gomes, como “[...] a obrigação de repor recursos públicos (imputação de débito) ou de suportar as sançóes previstas em lei, no âmbito do controle exercido pelos Tribunais de Contas, em razão da violação de normas pertinentes à gestão de bens, dinheiros e valores públicos" 531 . Por isso a opção, neste trabalho, de apresentar as funções sancionadora e reintegradora das cortes de contas, ao mesmo tempo, numa só subseção.

Segundo João Ricardo Catarino, a responsabilidade financeira reintegratória “[...] visa a plena reconstituição da situação anterior à lesão (reposições) dos interesses públicos, com a restituição dos valores ou bens públicos alcançados”, ao passo que a responsabilidade financeira sancionatória “[...] visa o estabelecimento de uma sanção, isto é, de uma consequência desfavorável para o violador da norma, a determinar segundo o desvalor da ação" 532 . Outrossim, Maria d'Oliveira Martins ${ }^{533}$ associa a responsabilidade financeira reintegratória à condenação de reposição de verbas e a sancionatória à aplicação de multas.

Como demonstra Emerson Cesar da Silva Gomes, a atribuição de responsabilidade financeira reintegratória a determinado agente público ou equiparado, ou particular que atue em conluio com aquele ${ }^{534}$, com a imposição da obrigação de repor as quantias correspondentes ao dano causado ao erário, exige "[...] a conduta humana voluntária, o dano ao erário, a violação de normas pertinentes à gestão pública, o nexo de causalidade, a culpabilidade e a ausência de excludentes de responsabilidade" 535 . Por outro lado, como explica $^{536}$, a aposição de responsabilidade financeira sancionatória, com a aplicação de multa, não requer a ocorrência de dano ao erário, podendo decorrer da violação a normas de gestão ou aos deveres de colaboração com as cortes de controle externo.

531 GOMES, Emerson Cesar da Silva. Responsabilidade financeira: uma teoria sobre a responsabilidade no âmbito dos tribunais de contas. 2009. 379 f. Dissertação (Mestrado em Direito) - Departamento de Direito Econômico, Financeiro e Tributário, Faculdade de Direito, Universidade de São Paulo, São Paulo, 2009. f. 32.

532 CATARINO, João Ricardo. Finanças públicas e direito financeiro. 4. ed. Coimbra: Almedina, 2018. p. 422-423.

533 MARTINS, Maria D’Oliveira. Liçóes de finanças públicas e direito financeiro. 3. ed. Coimbra: Almedina, 2015. p. 289-291.

534 A respeito da possibilidade de os tribunais de contas sancionarem agentes privados contratados pela Administração Pública, cf. ROSILHO, André Janjácomo. Controle da administração pública pelo Tribunal de Contas da União. 2016. 358 f. Tese (Doutorado em Direito) - Departamento de Direito do Estado, Faculdade de Direito, Universidade de São Paulo, São Paulo, 2016. f. 89-90; 174-175; 187-188.

535 GOMES, Emerson Cesar da Silva. Responsabilidade financeira: uma teoria sobre a responsabilidade no âmbito dos tribunais de contas. 2009. 379 f. Dissertação (Mestrado em Direito) - Departamento de Direito Econômico, Financeiro e Tributário, Faculdade de Direito, Universidade de São Paulo, São Paulo, 2009. f. 181-182.

536 GOMES, Emerson Cesar da Silva. Responsabilidade financeira: uma teoria sobre a responsabilidade no âmbito dos tribunais de contas. 2009. 379 f. Dissertação (Mestrado em Direito) - Departamento de Direito Econômico, Financeiro e Tributário, Faculdade de Direito, Universidade de São Paulo, São Paulo, 2009. f. 169. 
Os requisitos demandados para a configuração da responsabilidade financeira sancionatória também se estendem às sanções aplicáveis pelos tribunais de contas que não têm caráter patrimonial, como a inabilitação para o exercício de cargo em comissão ou função de confiança e a declaração de inidoneidade de licitante fraudador.

Emerson Cesar da Silva Gomes ${ }^{537}$, em lição aplicável também às sanções de caráter não patrimonial indicadas no parágrafo anterior, deixa claro que a responsabilidade financeira, seja reintegratória, seja sancionatória, tem natureza subjetiva. Nesse sentido, por força do artigo 28 da LINDB, para atribuir responsabilidade financeira reintegratória ou sancionar os agentes públicos ou equiparados, as cortes de contas devem evidenciar que eles agiram, por ação ou omissão, com dolo ou erro grosseiro.

O dolo estará presente, como explicam Gustavo Binenbojm e André Cyrino, "[...] quando o gestor agir com intenção de praticar um ato contrário à Administração Pública" 538 . Embora, em muitos casos, não seja simples ou possível a sua prova nos processos de controle externo, o conceito de dolo é algo já consolidado no âmbito dos tribunais de contas.

A exigência de erro grosseiro pelo artigo 28 da LINDB, por outro lado, afeta, de forma relevante, os processos de controle externo, nos quais, em regra, contentava-se com a verificação de culpa para a configuração da responsabilidade. Agora, conforme Rafael Maffini e Juliano Heinen, “[...] não mais se poderá cogitar de responsabilização pessoal de agentes públicos nos casos de decisões ou opiniōes técnicas culposamente equivocadas, inadequadas ou mesmo contrárias ao direito, se esta não caracterizar erro grosseiro" 539 . Como alertam Floriano de Azevedo Marques Neto e Rafael Véras de Freitas ${ }^{540}$, não configuram erro grosseiro aquelas situações de divergência de interpretações entre o agente público e as cortes de contas, mas a sua atuação desidiosa.

Tendo em conta a natureza subjetiva da responsabilidade perante os tribunais de contas, pode-se traduzir o sentido da expressão "erro grosseiro" pelo conceito de culpa

537 GOMES, Emerson Cesar da Silva. Responsabilidade financeira: uma teoria sobre a responsabilidade no âmbito dos tribunais de contas. 2009. 379 f. Dissertação (Mestrado em Direito) - Departamento de Direito Econômico, Financeiro e Tributário, Faculdade de Direito, Universidade de São Paulo, São Paulo, 2009. f. 40; 205.

538 BINENBOJM, Gustavo; CYRINO, André. O art. 28 da LINDB: A cláusula geral do erro administrativo. Revista de Direito Administrativo, Rio de Janeiro, Edição Especial: Direito Público na Lei de Introdução às Normas de Direito Brasileiro - LINDB (Lei n. 13.655/2018). p. 203-224, nov. 2018. DOI: $10.12660 /$ rda.v0.2018.77655. p. 211.

539 MAFFINI, Rafael; HEINEN, Juliano. Análise acerca da aplicação da Lei de Introdução às Normas do Direito Brasileiro (na redação dada pela Lei 13.655/2018) no que concerne à interpretação de normas de direito público: operações interpretativas e princípios gerais de direito administrativo. Revista de Direito Administrativo, São Paulo, v. 277, n. 3, p. 247-278. DOI: 10.12660/rda.v277.2018.77683. p. 266.

540 MARQUES NETO, Floriano de Azevedo. FREITAS, Rafael Véras de. O artigo 28 da nova LINDB: um regime jurídico para o administrador honesto. Revista Consultor Jurídico, São Paulo, 25 maio 2018. Disponível em: https://www.conjur.com.br/2018-mai-25/opiniao-lindb-regime-juridico-administrador-honesto. Acesso em: 27 out. 2019. 


\section{-• Contas dos governantes}

grave. É o que defendem Thiago Priess Valiati e Manoela Virmond Munhoz ${ }^{541}$, Pericles Ferreira de Almeida ${ }^{542}$ e Guilherme Salgueiro Pacheco de Aguiar $^{543}$.

Por sua vez, o artigo 22, caput e parágrafos, da LINDB vindica a consideração, pelas cortes de controle externo, das circunstâncias práticas que conformaram a atuação do agente, das suas dificuldades reais na gestão e das exigências por ele suportadas, inclusive como circunstâncias agravantes ou atenuantes para fim de aplicação de sanções. Assim, como leciona Eduardo Jordão, na aplicação de sanções, os tribunais de contas devem considerar: "(i) danos para a administração, (ii) agravantes, (iii) atenuantes, (iv) antecedentes do agente e (v) outras sanções de mesma natureza e relativas ao mesmo que lhe tenham sido aplicadas" ${ }^{54}$.

Neste ponto, é importante esclarecer a relação das funções sancionadora e reintegradora das cortes de contas com suas demais funções. Para Heloísa Helena Antonacio M. Godinho ${ }^{545}$, a competência sancionadora dos tribunais de contas estaria vinculada unicamente ao exercício de sua função judicante. Contudo, como percebe Emerson Cesar da Silva Gomes ${ }^{546}$, a responsabilidade financeira pode ser efetivada, também, em processos de fiscalização, onde não há contas a serem julgadas.

De fato, por meio da leitura do artigo 71, inciso VIII, da CRFB/1988, verifica-se que as sanções previstas podem ser aplicadas no caso de ilegalidade de despesa ou irregularidade de contas. Daí, pode-se fazer algumas inferências.

A primeira é que a irregularidade de contas não é uma sanção jurídica, mas um requisito objetivo para a sua aplicação, alternativo à ilegalidade de despesa. Por conseguinte,

541 VALIATI, Thiago Priess; MUNHOZ, Manoela Virmond. O impacto interpretativo da Lei $\mathrm{n}$. 13.655/2018 na aplicação da Lei de Improbidade Administrativa: a confiança no agente público de boa-fé para inovar na Administração Pública. Revista Brasileira de Direito Público - RBDP, Belo Horizonte, a. 16, n. 62, p. 161-186, jul./set. 2018. p. 175.

542 ALMEIDA, Pericles Ferreira de. Considerações sobre a nova Lei de Introdução às Normas do Direito Brasileiro (Lei n. 13.665/2018). Revista de Direito Público da Economia - RDPE, Belo Horizonte, a. 16, n. 64, p. 147-174, out./dez. 2018. p. 156.

543 AGUIAR, Guilherme Salgueiro Pacheco de. Lei n. 13.655/18 - Análise dos arts. 20 a 30 da LINDB e primeiras impressões de sua utilização na conformação das atuações dos diferentes órgãos de controle. Fórum Administrativo - FA, Belo Horizonte, a. 19, n. 215, p. 9-21, jan. 2019. p. 18

544 JORDÃO, Eduardo. Art. 22 da LINDB: acabou o romance: reforço do pragmatismo no direito público brasileiro. Revista de Direito Administrativo, Rio de Janeiro, Edição Especial: Direito Público na Lei de Introdução às Normas de Direito Brasileiro - LINDB (Lei n. 13.655/2018). p. 63-92, nov. 2018. DOI: $10.12660 /$ rda.v0.2018.77650. p. 85.

545 GODINHO, Heloísa Helena Antonacio M. Ideias no lugar: as decisões condenatórias proferidas pelos tribunais de contas. SARQUIS, Alexandre Manir Figueiredo. Citação e revelia no processo de contas. In: LIMA, Luiz Henrique; SARQUIS, Alexandre Manir Figueiredo (Coord.). Processos de controle externo: estudos de ministros e conselheiros substitutos dos tribunais de contas. Belo Horizonte: Fórum, 2019. p. 223-224.

546 GOMES, Emerson Cesar da Silva. Responsabilidade financeira: uma teoria sobre a responsabilidade no âmbito dos tribunais de contas. 2009. 379 f. Dissertação (Mestrado em Direito) - Departamento de Direito Econômico, Financeiro e Tributário, Faculdade de Direito, Universidade de São Paulo, São Paulo, 2009. f. 40; 306. 
o simples fato de uma corte de contas julgar irregulares as contas prestadas por determinado agente público, ou dele tomadas, não é uma sanção jurídica. Não se pode confundir o julgamento das contas com a, eventual, aplicação de sanção jurídica que dele pode resultar.

A segunda é que sanções podem ser aplicadas ainda que não haja julgamento de contas. Como a ilegalidade de despesa é um requisito objetivo alternativo à irregularidade de contas, não cumulativo, é possível, às cortes de controle externo, a aplicação de sanções em processos que sequer julgam contas, como os processos de fiscalização.

Por corolário das duas, pode-se afirmar que não existe essa conexão obrigatória entre a competência sancionadora dos tribunais de contas e o exercício de sua função judicante. Desse modo, a função sancionadora é autônoma, podendo ser exercida pelas cortes de contas em conjunto tanto com a função fiscalizadora quanto com a função judicante, tratadas, respectivamente, nas subseções 2.6.7 (p. 146) e 2.6.8 (p. 157) deste trabalho.

Tal conclusão, vale dizer, é válida também para a função reintegradora. Como se baseia em competência específica, prevista no $\$ 3^{\circ}$ do artigo 71 da CRFB/1988, não há motivo para cogitar que ela depende de quaisquer das outras funções.

Em razão de sua natureza subjetiva, as funções sancionadora e reintegradora, independentemente de julgamento de contas, reclamam o exame cuidadoso da responsabilidade dos agentes públicos, com indicação, apoiada em evidências, da conduta - dolosa ou com erro grosseiro -, do nexo de causalidade entre a conduta e o resultado ilícito e da culpabilidade do agente. $\mathrm{Na}$ ausência de algum desses requisitos, não poderá ser atribuída responsabilidade financeira reintegratória ou sancionatória ao agente público ou equiparado, nem lhe poderá ser aplicada sanção não patrimonial.

Finalmente, é interessante destacar que, conforme o $\$ 3^{\circ}$ do artigo 71 da $\mathrm{CRFB} / 1988$, as decisões dos tribunais de contas que resultarem em imputação de débito ou multa têm eficácia de título executivo extrajudicial. Note-se que este é o único título executivo previsto na própria Constituição de 1988.

Portanto, as cortes de controle externo têm competência para imputar débito função reintegradora -, aplicar multas, inabilitar para o exercício de cargo em comissão ou função de confiança e declarar a inidoneidade de licitante fraudador - função sancionadora. Delas se exige, contudo, a demonstração individual da responsabilidade, com a presença de dolo ou erro grosseiro, daquele que estiver sujeito à condenação em débito ou à sanção jurídica, com a consideração das circunstâncias práticas, obstáculos e dificuldades reais, além das exigências por ele suportadas na gestão.

\subsubsection{Função informativa}

A função informativa dos tribunais de contas, prevista na classificação adotada de José Mauricio Conti, abrange as competências previstas nos incisos VII e XI do artigo 71 da CRFB/1988. Assim, no exercício dessa função, conforme o artigo 71, inciso VII, da CRFB/1988, cabe às cortes de contas prestar as informaçôes solicitadas 


\section{•- Contas dos governantes}

pelo Legislativo - inclusive suas comissões -, sobre a fiscalização financeira e orçamentária da Administração Pública e, especificamente, sobre resultados de auditorias e inspeções realizadas.

Deve-se recordar que, conforme apresentado na seção 2.5 (p. 104) deste trabalho, as ISC foram criadas, justamente, em decorrência da incapacidade do Poder Legislativo para exercer isoladamente a accountability horizontal sobre a gestão financeira e orçamentária da Administração Pública. Logo, nada mais natural e condizente com o sistema de accountability financeira e orçamentária que exigir que a agência especializada - o tribunal de contas, no caso brasileiro -, sempre que solicitada, preste ao parlamento todas as informações tanto sobre quais fiscalizaçôes são promovidas e de que modo são exercidas, como a respeito dos resultados obtidos a partir de sua realização.

Como dito, também se insere na função informativa a legitimidade concedida às cortes de contas, pelo artigo 71, inciso XI, da CRFB/1988, para "representar ao Poder competente sobre irregularidades ou abusos apurados" ${ }^{547}$. Tal competência responde à advertência realizada por Guillermo O’Donnell, de que “[...] a efetividade da accountability horizontal depende não apenas de agências isoladas lidando com questôes específicas mas com uma rede dessas agências que inclui tribunais comprometidos com o apoio a esse tipo de accountability" " 48 . Assim, quando observarem irregularidades ou abusos cuja apuração e responsabilização não é de sua competência, ou a ultrapassa, as cortes de controle externo estão habilitadas e obrigadas a representar perante a instituição juridicamente capaz de responsabilizar os envolvidos.

Conclui-se, desse modo, que a função informativa, apresentada nesta subseção, assume um importante papel de integração orgânica no sistema constitucional de $a c$ countability da gestão financeira e orçamentária da Administração Pública. Opera tanto na integração entre os agentes de accountability financeira e orçamentária - parlamentos e tribunais de contas - quanto entre eles e os demais agentes de accountability pública.

\subsubsection{Função fiscalizadora}

O exercício da função fiscalizadora pelas cortes de contas abrange uma ampla gama de atividades. Envolve desde o registro de atos de pessoal, previsto no inciso III do artigo 71 da CRFB/1988, à fiscalização da gestão fiscal e de atos e contratos, de repasses a outros entes da federação e a particulares, das desestatizações, da gestão do patrimônio, do pagamento de salários e benefícios a seus servidores e de benefícios previdenciários e assistenciais, do desempenho de entidades governamentais, projetos e programas de governo, da renúncia de receitas etc., como esclarecem as subseções seguintes.

547 BRASIL. Constituição (1988). Constituição da República Federativa do Brasil. Disponível em: http:// www.planalto.gov.br/ccivil_03/Constituicao/Constituicao.htm. Acesso em: 2 dez. 2019.

548 O'DONNELL, Guillermo. Accountability horizontal e novas poliarquias. Lua Nova, São Paulo, n. 44, p. 27-54, 1998. p. 45-46. 


\subsubsection{Fiscalização dos atos de pessoal sujeitos a registro}

No âmbito da função fiscalizadora, os tribunais de contas possuem competência de apreciar, para fins de registro, a legalidade dos atos de admissão de pessoal, bem como a das concessões de aposentadorias, reformas e pensões. Trata-se de examinar, no que tange à sua legalidade, os atos referidos - com exceção das nomeações para cargo de provimento em comissão - e determinar o seu registro, ou negá-lo se o considerar ilegal.

Considerando a ressalva "[...] às melhorias posteriores que não alterem o fundamento legal do ato concessório" ${ }^{449}$, feita na parte final do artigo 71, inciso III, da CRFB/1988, Fernando Bessa de Almeida alerta que a competência das cortes de controle externo restringe-se aos atos iniciais de concessão de aposentadoria ${ }^{550}$. Como destacou Odete Medauar, o registro dos atos de admissão e concessão de aposentadorias, reformas e pensōes, trata "[...] da verificação de legalidade de atos e procedimentos (concursos) administrativos, sem o caráter de função jurisdicional” "551.

É, como destacou Luciano Brandão Alves de Souza ${ }^{552}$, uma competência extensa, que envolve um enorme número de processos. Para se ter uma ideia, os processos de registro de atos de pessoal, em 2018, representaram $96,8 \%{ }^{553}$ da quantidade de processos de controle externo apreciados conclusivamente no TCU.

Embora a fiscalização dos atos de pessoal sujeitos a registro não se relacione diretamente com o objeto específico deste trabalho, é necessário destacar que a concepção tradicional, segundo a qual o ato de concessão de aposentadoria, reforma ou pensão seria um ato complexo, cuja formação depende do concurso de duas ou mais vontades - que motivou a edição da Súmula Vinculante n. 3, pelo STF -, tem sido contestada recentemente, com repercussóes jurisprudenciais, pelos que defendem que o registro pelos tribunais de contas é ato de controle, que não integra o ato de concessão. Tal discussão tem importantes consequências para a extensão do contraditório exigido nos processos de registro que tramitam nas cortes de contas ${ }^{554}$.

549 BRASIL. Constituição (1988). Constituição da República Federativa do Brasil. Disponível em: http:// www.planalto.gov.br/ccivil_03/Constituicao/Constituicao.htm. Acesso em: 2 dez. 2019.

550 ALMEIDA, Fernando Bessa de. A fiscalização financeira e orçamentária na Constituição de 1967. Revista de Administração Pública, Rio de Janeiro, n. 1, p. 103-143, 1967. p. 137.

551 MEDAUAR, Odete. Controle da administração pública pelo tribunal de contas. Revista de Informação Legislativa, Brasília, v. 27, n. 108, p. 101-126, out./dez. 1990. p. 119-120.

552 SOUZA, Luciano Brandão Alves de. A Constituição de 1988 e o Tribunal de Contas da União. Revista de Informação Legislativa, Brasília, a. 26, n. 102, p. 173-184, abr./jun. 1989. p. 177.

553 Cf. BRASIL. Tribunal de Contas da União. Relatório anual de atividades do TCU: 2018. Brasília: Tribunal de Contas da União, 2019. Disponível em: https://portal.tcu.gov.br/transparencia/relatorios/ relatorios-de-atividades/relatorios-de-atividades.htm. Acesso em: 30 out. 2019. p. 45 ; 47.

554 A respeito da natureza do ato de concessão de aposentadoria, reforma ou pensão, e da extensão do contraditório nos processos de atos de pessoal sujeitos a registro dos tribunais de contas, cf. BUZAID, Alfredo. O tribunal de contas no Brasil. Revista da Faculdade de Direito da Universidade de São 


\subsubsection{Fiscalização stricto sensu}

Além da competência inserta no inciso III do artigo 71 da CRFB/1988, referente ao registro de atos de pessoal, também são classificadas dentro da função fiscalizadora aquelas previstas nos incisos IV, V e VI do referido artigo constitucional. Trata-se do exercício do que se denomina, neste trabalho, fiscalização stricto sensu.

Sujeitam-se à fiscalização stricto sensu dos tribunais de contas, conforme combinação dos incisos II e IV do artigo 71 da CRFB/1988, as unidades administrativas do Legislativo, do Executivo, do Judiciário, dos ministérios públicos, das defensorias públicas e dos TCM, nos estados em que houver, abrangendo os órgãos da administração direta e indireta, inclusive as fundações, as empresas públicas e as sociedades de economia mista.

Tal competência não está restrita ao TCU, estendendo-se às cortes de controle externo dos entes subnacionais, em razão do artigo 75 da CRFB/1988. Dessa forma, em todos os âmbitos federativos, as cortes de contas têm competência para fiscalizar todas as unidades administrativas dos três poderes e dos demais órgãos independentes, da administração direta e indireta.

Destaque-se, contudo, que, em razão do artigo 71, inciso VI, da CRFB/1988, a competência para fiscalizar é definida não em função do âmbito federativo ao qual

Paulo, São Paulo, v. 62, n. 2, p. 37-62, 1967. p. 52; CAVALCANTI, Themístocles Brandão. O tribunal de contas - órgão constitucional - funçōes próprias e funçōes delegadas. Revista de Direito Administrativo, Rio de Janeiro, v. 109, p. 1-10, 1972. p. 9; NETTO, Luísa Cristina Pinto e. Ato de aposentadoria natureza jurídica, registro pelo tribunal de contas e decadência. Revista Brasileira de Direito Público - RBDP, Belo Horizonte, v. 4, n. 13, p. 119-146, abr./jun. 2006. Disponível em: http://bidforum. com.br/bidBiblioteca_periodico_telacheia_pesquisa.aspx?i=36080\&p=6. Acesso em: 26 abr. 2017. p. 22 (Versão digital); BRASIL. Supremo Tribunal Federal. Súmulas vinculantes. Atualizado em $1^{\circ} \mathrm{de}$ dezembro de 2017. Brasília: Supremo Tribunal Federal, 2017. Disponível em: http://www.stf.jus.br/arquivo/cms/jurisprudenciaSumulaVinculante/anexo/Enunciados_Sumula_Vinculante_STF_Completo.pdf. Acesso em: 30 out. 2019. p. 8; BRASIL. Supremo Tribunal Federal. Mandado de segurança n. 25.116 Distrito Federal. Relator: Ministro Ayres Britto. Plenário, Brasília, 8 de setembro de 2010. Diário da Justiça Eletrônico, Brasília, n. 27, 10 fev. 2011. Disponível em: http://redir.stf.jus.br/paginadorpub/paginador.jsp?docTP=AC\&docID=618869. Acesso em: 27 abr. 2017; LEVY, José Luiz. O Supremo Tribunal Federal e o registro das aposentadorias pelo tribunal de contas. Fórum Administrativo - FA, Belo Horizonte, v. 10, n. 115, p. 24-29, set. 2010. Disponível em: http://www.bidforum.com.br/ bid/PDI0006.aspx?.pdiCntd=69250. Acesso em: 26 abr. 2017. p. 1 (Versão digital); MOTTA, Fabrício. $\mathrm{O}$ registro dos atos de aposentadoria pelos Tribunais de Contas. Fórum de Contrataçáo e Gestão Pública - FCGP, Belo Horizonte, a. 12, n. 134, p. 9-19, fev. 2013. Disponível em: http://www.bidforum.com.br/bid/PDI0006.aspx?pdiCntd=86518. Acesso em: 27 abr. 2017; CRUZ, André Gonzalez. A natureza jurídica dos atos concessivos de aposentadoria, reforma e pensão. Revista Brasileira de Direito Público - RBDP, Belo Horizonte, a. 11, n. 43, p. 53-113, out./dez. 2013. Disponível em: http:// www.bidforum.com.br/bid/PDI0006.aspx?pdiCntd=98868. Acesso em: 27 abr. 2017; CRUZ, André Gonzalez. A tipicidade dos efeitos jurídicos dos atos concessivos de aposentadoria, reforma e pensão. Revista Brasileira de Direito Público - RBDP, Belo Horizonte, v. 13, n. 50, p. 165-177, jul./set. 2015; e CRUZ, André Gonzalez. Os atos concessivos de aposentadoria, reforma e pensão, o princípio constitucional da segurança jurídica e a decadência administrativa. Revista Brasileira de Direito Público RBDP, Belo Horizonte, v. 14, n. 54, p. 71-90, jul./set. 2016. 
pertence a unidade administrativa que aplica os recursos públicos, mas em razão da origem dos recursos. Logo, nem sempre é o tribunal de contas do mesmo âmbito federativo da unidade administrativa fiscalizada o competente para fiscalizar a aplicação de determinado recurso por ela aplicado.

Isso ocorre porque, nos termos do artigo 71, inciso VI, da CRFB/1988, é competência do TCU, fiscalizar a aplicação de recursos que tenham sido repassados a estados, a municípios ou ao DF, apesar da existência de cortes de contas subnacionais. Da mesma forma, por paralelismo constitucional e por expressa previsão nas constituições estaduais, são competentes para fiscalizar recursos repassados por estado aos seus municípios os respectivos tribunais de contas estaduais, ainda que existam cortes de controle externo municipais.

Além das fundações, as empresas públicas e as sociedades de economia mista, por força do inciso V do artigo 71 da CRFB/1988, também é competência do TCU "fiscalizar as contas nacionais das empresas supranacionais de cujo capital social a União participe, de forma direta ou indireta, nos termos do tratado constitutivo" 555 . Do mesmo modo, algumas casas legislativas, de entes subnacionais que possuem suas próprias cortes de contas, fizeram constar nas constituiçóes estaduais ou leis orgânicas municipais, conforme o caso, normas que entenderam espelho da apresentada.

Portanto, existindo empresas que estejam na condição descrita, a exemplo de Itaipu Binacional, sua fiscalização deve ser realizada na forma definida no tratado constitutivo. Luciano Brandão Alves de Souza ${ }^{556}$ destacou o acerto da medida, tendo o constituinte colocado sob vigilância parcela relevante de investimentos públicos que anteriormente se encontravam fora do alcance dos órgãos de controle.

Quanto ao seu objeto, a fiscalização stricto sensu a cargo das cortes de controle externo deve estender-se muito além dos atos e contratos administrativos. Desse modo, como ensina Lucas Rocha Furtado, "Ele vai além e compreende o planejamento e a execução dos programas de governo. [...] qualquer programa de governo pode ser objeto de procedimento fiscalizatório [...]" 557 pelos tribunais de contas.

Para cumprir sua atribuição de fiscalização, as cortes de contas do Brasil lançam mão dos chamados instrumentos de fiscalização. Dois deles são previstos no artigo 71, inciso IV, da CRFB/1988, quais sejam, a auditoria e a inspeção. Ademais, as leis orgânicas e os regimentos internos guarnecem as cortes de controle externo de variaçóes desses instrumentos de fiscalização. É o caso, por exemplo, dos levantamentos - ou auditorias de levantamento -, dos acompanhamentos e dos monitoramentos.

555 BRASIL. Constituição (1988). Constituição da República Federativa do Brasil. Disponível em: http:// www.planalto.gov.br/ccivil_03/Constituicao/Constituicao.htm. Acesso em: 2 dez. 2019.

556 SOUZA, Luciano Brandão Alves de. A Constituição de 1988 e o Tribunal de Contas da União. Revista de Informação Legislativa, Brasília, v. 26, n. 102, p. 173-184, abr./jun. 1989. p. 176.

557 FURTADO, Lucas Rocha. Curso de direito administrativo. 5. ed. Belo Horizonte: Fórum, 2016. p. 970. 
De acordo com Luiz Fernando Rodrigues Pinto Junior, a auditoria é o “[...] principal instrumento efetivo de verificação das contas e do gerenciamento do patrimônio público junto à administração pública [...]" ${ }^{558}$. De fato, na medida em que possibilita o exame profundo e verticalizado de diversos aspectos do objeto auditado, a auditoria possui grande potencial de contribuir para um adequado e responsável gerenciamento financeiro e orçamentário da Administração Pública.

Ela é descrita pela INTOSAI, como "[...] um processo sistemático de obter e avaliar objetivamente evidência para determinar se a informação ou as condiçôes reais de um objeto estão de acordo com critérios estabelecidos" ${ }^{59}$. Esse conceito é, em geral, correspondente àqueles apresentados nas normas de auditoria adotadas pelos tribunais de contas brasileiros, como as Normas Brasileiras de Auditoria do Setor Público (NBASP), as Normas de Auditoria Governamental (NAG), as Normas de Auditoria do TCU (NAT) e o Manual de auditoria de conformidade do Tribunal de Contas do Estado do Espírito Santo (TCE-ES) ${ }^{560}$.

Como conceito analítico, ele pode ser desdobrado em oito elementos, a saber, (i) processo sistemático; (ii) processo documentado; (iii) processo independente; (iv) avaliação objetiva; (v) situação ou condição; (vi) critério; (vii) evidências; e (viii) comunicação de resultados, como nas $\mathrm{NAT}^{561}$.

558 PINTO JUNIOR, Luiz Fernando Rodrigues. Fiscalização patrimonial da administração pública. 2013. 303 f. Dissertação (Mestrado em Direito) - Departamento de Direito Econômico, Financeiro e Tributário, Faculdade de Direito, Universidade de São Paulo, São Paulo, 2013. p. 165.

559 INTERNATIONAL ORGANIZATION OF SUPREME AUDIT INSTITUTIONS (INTOSAI). The International Standards of Supreme Audit Institutions (ISSAI). INTOSAI Standards. ISSAI 100: Princípios fundamentais de auditoria do setor público, Beijing, 2013. Traduzida pelo Tribunal de Contas da União. Brasília: Tribunal de Contas da União, 2015. Disponível em: https://portal.tcu.gov.br/ fiscalizacao-e-controle/auditoria/normas-internacionais-das-entidades-fiscalizadores-superiores-issai/. Acesso em: 30 out. 2019. p. 3.

560 INSTITUTO RUI BARBOSA. Normas brasileiras de auditoria do setor público (NBASP): Nível 2. Belo Horizonte: Instituto Rui Barbosa, 2017. Disponível em: https://irbcontas.org.br/wp-content/ uploads/woocommerce_uploads/2019/05/irb-nbasp-nivel2.pdf. Acesso em: 30 out. 2019. p. 5-6; INSTITUTO RUI BARBOSA. Normas de auditoria governamental (NAG): aplicáveis ao controle externo brasileiro. Palmas: Instituto Rui Barbosa, 2011. p. 11; BRASIL. Tribunal de Contas da União. Normas de auditoria do Tribunal de Contas da União: Revisão Junho/2011. Boletim do Tribunal de Contas da União: Especial, Brasília, a. XLIV, n. 12, 5 jul. 2011. Disponível em: https://portal.tcu.gov. $\mathrm{br} /$ controle-externo/normas-e-orientacoes/normas-de-fiscalizacao/nat.htm. Acesso em: 30 out. 2019. p. 13; e ESPÍRITO SANTO. Tribunal de Contas do Estado. Resoluçáo n. 287, de 5 de maio de 2015. Aprova o Manual de auditoria de conformidade do Tribunal de Contas do Estado do Espírito Santo. Vitória: Tribunal de Contas do Estado do Espírito Santo, 2015. Disponível em: https://www.tce.es.gov. br/wp-content/uploads/2017/07/Res287-2015-Aprova-o-Manual-de-Auditoria-de-Conformidade-do-TCEES-Assinado-1.pdf. Acesso em 30 out. 2019. p. 20.

561 BRASIL. Tribunal de Contas da União. Normas de auditoria do Tribunal de Contas da União: Revisão Junho/2011. Boletim do Tribunal de Contas da União: Especial, Brasília, a. XLIV, n. 12, 5 jul. 2011. Disponível em: https://portal.tcu.gov.br/controle-externo/normas-e-orientacoes/normas-de-fiscalizacao/nat.htm. Acesso em: 30 out. 2019. p. 13-14. 
Considerando a doutrina especializada ${ }^{562}$, as Normas Internacionais das Instituições Superiores de Controle (ISSAI) ${ }^{563}$ e outras normas de abrangência nacional ${ }^{564} \mathrm{e}$ local ${ }^{565}$, aplicáveis às auditorias empreendidas pelo controle externo, em geral, elas são classificadas em auditorias de regularidade, abrangendo as financeiras e as de conformidade, e auditorias operacionais - ou de desempenho.

Nesse contexto, de acordo com a INTOSAI, "A auditoria de conformidade é a avaliação independente para determinar se um dado objeto está em conformidade com normas aplicáveis identificadas como critérios" ${ }^{156}$. Portanto, as auditorias de conformidade têm como objetivo verificar o cumprimento das disposiçōes legais e regulamentares aplicáveis às atividades administrativas.

Por sua vez, a auditoria financeira - ou auditoria contábili56 - visa verificar se as demonstrações contábeis e outros relatórios financeiros foram apresentados de forma

${ }^{562}$ Cf. FONTICIELLA, Maria Teresa Ruiz. La auditoría operativa de gestión pública y los organismos de control externo (OCEx). El caso español. INNOVAR, Revista de Ciências Administrativas y Sociales, Bogotá, p. 120-137, ene./jun. 2005. p. 120.

563 Cf. INTERNATIONAL ORGANIZATION OF SUPREME AUDIT INSTITUTIONS (INTOSAI). INTOSAI Principles. INTOSAI Founding Principles. INTOSAI-P 1: The Lima declaration. Lima: INTOSAI, 1977. Disponível em: https://www.issai.org/pronouncements/intosai-p-1-the-lima-declaration/. Acesso em: 17 out. 2019. p. 8; INTERNATIONAL ORGANIZATION OF SUPREME AUDIT INSTITUTIONS (INTOSAI). The International Standards of Supreme Audit Institutions (ISSAI). INTOSAI Standards. ISSAI 100: Fundamental principles of public-sector auditing. Beijing: INTOSAI, 2013. Disponível em: https://www.issai.org/professional-pronouncements/?n=0-1000000000. Acesso em: 30 out. 2019. p. 11-12.

564 Cf. INSTITUTO RUI BARBOSA. Normas brasileiras de auditoria do setor público (NBASP): Nível 1. Belo Horizonte: Instituto Rui Barbosa, 2015. Disponível em: https://irbcontas.org.br/wp-content/uploads/woocommerce_uploads/2019/05/irb-nbasp-nivel1.pdf. Acesso em: 30 out. 2019. p. 2930; INSTITUTO RUI BARBOSA. Normas de auditoria governamental (NAG): aplicáveis ao controle externo brasileiro. Palmas: Instituto Rui Barbosa, 2011. p. 11-12; BRASIL. Tribunal de Contas da União. Normas de auditoria do Tribunal de Contas da União: Revisão Junho/2011. Boletim do Tribunal de Contas da Uniáo: Especial, Brasília, a. XLIV, n. 12, 5 jul. 2011. Disponível em: https://portal. tcu.gov.br/controle-externo/normas-e-orientacoes/normas-de-fiscalizacao/nat.htm. Acesso em: 30 out. 2019. p. 14

565 Cf. ESPÍRITO SANTO. Tribunal de Contas do Estado. Resolução n. 287, de 5 de maio de 2015. Aprova o Manual de auditoria de conformidade do Tribunal de Contas do Estado do Espírito Santo. Vitória: Tribunal de Contas do Estado do Espírito Santo, 2015. Disponível em: https://www.tce.es.gov. br/wp-content/uploads/2017/07/Res287-2015-Aprova-o-Manual-de-Auditoria-de-Conformidade-do-TCEES-Assinado-1.pdf. Acesso em 30 out. 2019. p. 20.

566 INTERNATIONAL ORGANIZATION OF SUPREME AUDIT INSTITUTIONS (INTOSAI). The International Standards of Supreme Audit Institutions (ISSAI). INTOSAI Standards. ISSAI 400: Princípios fundamentais de auditoria de conformidade, Beijing, 2013. Traduzida pelo Tribunal de Contas da União. Brasília: Tribunal de Contas da União, 2015. Disponível em: https://portal.tcu.gov.br/ fiscalizacao-e-controle/auditoria/normas-internacionais-das-entidades-fiscalizadores-superiores-issai/. Acesso em: 30 out. 2019. p. 3.

567 A respeito da melhor denominação para a auditoria financeira, cf. CUNHA, Isaias Lopes da. A auditoria contábil financeira e o julgamento das contas públicas. In: LIMA, Luiz Henrique; OLIVEIRA, Weder de; CAMARGO, João Batista (Coord.). Contas governamentais e responsabilidade fiscal. Belo Horizonte: Fórum, 2017. p. 260. 


\section{-• Contas dos governantes}

adequada à legislação pertinente e se apresentam uma visão fiel e justa do patrimônio. Nesse sentido, segundo a INTOSAI, "A auditoria financeira tem como foco determinar se a informação financeira de uma entidade é apresentada de acordo com o marco regulatório e a estrutura de relatório financeiro aplicável" ${ }^{568}$. Nos tribunais de contas, elas têm aplicação, por exemplo, na apreciação anual dos balanços gerais, no julgamento das contas anuais dos administradores e demais responsáveis por dinheiros, bens e valores públicos e nas auditorias específicas de contas contábeis de alto risco, como registra o Manual de auditoria financeira do TCU ${ }^{569}$.

Por fim, as auditorias operacionais têm o objetivo de avaliar o desempenho de instituições governamentais e programas de governo, especialmente quanto aos aspectos da economicidade, eficiência, eficácia e efetividade. É nesse sentido o conceito adotado pela INTOSAI, apresentado nos seguintes termos:

A auditoria operacional, como realizada pelas EFS [ISC], é o exame independente, objetivo e confiável que analisa se os empreendimentos, sistemas, operaçōes, programas, atividades ou organizações do governo estão funcionando de acordo com os princípios da economicidade, eficiência e efetividade e se há espaço para aperfeiçoamento $0^{570}$.

Nesse ínterim, como referência, para a INTOSAI, economicidade é minimizar os custos dos recursos - "Os recursos usados devem estar disponíveis tempestivamente, em quantidade suficiente, na qualidade apropriada e com o melhor preço" -, eficiência é obter o máximo dos recursos disponíveis - "Diz respeito à relação entre recursos empregados e produtos entregues em termos de quantidade, qualidade e tempestividade" - e efetividade "[...] diz respeito a atingir os objetivos estabelecidos e alcançar os resultados pretendidos" $" 571$.

568 INTERNATIONAL ORGANIZATION OF SUPREME AUDIT INSTITUTIONS (INTOSAI). The International Standards of Supreme Audit Institutions (ISSAI). INTOSAI Standards. ISSAI 200: Princípios fundamentais de auditoria financeira, Beijing, 2013. Traduzida pelo Tribunal de Contas da União. Brasília: Tribunal de Contas da União, 2015. Disponível em: https://portal.tcu.gov.br/fiscalizacao-e-controle/auditoria/normas-internacionais-das-entidades-fiscalizadores-superiores-issai/. Acesso em: 30 out. 2019. p. 1.

569 BRASIL. Tribunal de Contas da União. Manual de auditoria financeira. Brasília: Tribunal de Contas da União, 2016. Disponível em: https://portal.tcu.gov.br/controle-externo/normas-e-orientacoes/normas-de-fiscalizacao/auditoria-financeira.htm. Acesso em: 5 dez. 2019. p. 15.

570 INTERNATIONAL ORGANIZATION OF SUPREME AUDIT INSTITUTIONS (INTOSAI). The International Standards of Supreme Audit Institutions (ISSAI). INTOSAI Standards. ISSAI 300: Princípios fundamentais de auditoria operacional, Beijing, 2013. Traduzida pelo Tribunal de Contas da União. Brasília: Tribunal de Contas da União, 2015. Disponível em: https://portal.tcu.gov.br/fiscalizacao-e-controle/auditoria/normas-internacionais-das-entidades-fiscalizadores-superiores-issai/. Acesso em: 30 out. 2019. p. 2.

571 INTERNATIONAL ORGANIZATION OF SUPREME AUDIT INSTITUTIONS (INTOSAI). The International Standards of Supreme Audit Institutions (ISSAI). INTOSAI Standards. ISSAI 300: Princípios fundamentais de auditoria operacional, Beijing, 2013. Traduzida pelo Tribunal de Contas da União. Brasília: Tribunal de Contas da União, 2015. Disponível em: https://portal.tcu.gov.br/fiscalizacao-e-controle/auditoria/normas-internacionais-das-entidades-fiscalizadores-superiores-issai/. Acesso em: 30 out. 2019. p. 2-3. 
No Brasil, vale dizer, o critério da efetividade - effectiveness, no inglês -, relacionado nas normas internacionais, é usualmente desdobrado nos conceitos da eficácia e da efetividade, propriamente dito. Desse modo, nas NAG, a eficácia "diz respeito ao grau de realização de objetivos e de alcance das metas", e a efetividade "refere-se ao resultado real obtido pelos destinatários das políticas, dos programas e dos projetos públicos. É o impacto proporcionado pela ação governamental" 572 .

Fernando Luiz Abrucio e Maria Rita Loureiro ${ }^{573}$ destacam o papel das auditorias operacionais como instrumento de accountability. Para eles, ao avaliar os governantes eleitos e burocratas de acordo com o cumprimento das metas propostas, as cortes de contas geram informaçôes que melhoram o debate, servem como forma de controle, promovem o aprendizado cívico e contribuem para o exercício, pelos cidadãos, da $a c$ countability vertical.

As auditorias, em geral, desenvolvem-se nas fases de planejamento, execução e relatórios - ou comunicação de resultados. Em cada fase, é possível identificar como a auditoria se desenrola num processo sistemático, planejado e metódico. Nesse sentido, Enrique Quintanar Romero ${ }^{574}$ enxerga a auditoria como uma revisão formal e sistemática, enquanto Omar de Jesús Montilla Galvis e Luis Guillermo Herrera Marchena asseveram que

A auditoria é um processo de investigação sistemática que segue um planejamento e uma abordagem pormenorizada, devendo o planejamento prever todo o conjunto de fases e atividades a serem realizadas, bem como os recursos, tais como pessoal, tempo, ferramentas e espaço físico, entre outros, que serão necessários à sua realização ${ }^{575}$.

Por isso, os manuais e padrões de auditoria elaborados pelos tribunais de con$\operatorname{tas}^{576}$ colocam à disposição dos profissionais de auditoria governamental uma série de ferramentas que lhes permitem realizar a auditoria de forma segura e confiável.

${ }^{572}$ INSTITUTO RUI BARBOSA (IRB). Normas de auditoria governamental (NAG): aplicáveis ao controle externo brasileiro. Palmas: Instituto Rui Barbosa, 2011. p. 13.

573 ABRUCIO, Fernando Luiz; LOUREIRO, Maria Rita. Finanças públicas, democracia e accountability. In: ARVATE, Paulo Roberto; BIDERMAN, Ciro (Org.). Economia do setor público no Brasil. Rio de Janeiro: Elsevier/Campus, 2004. p. 84-85.

574 ROMERO, Enrique Quintanar. La auditoria operacional. Revista Espanola de Financiación y Contabilidad, Madrid, v. IX, n. 31, p. 151-70, ene./abr. 1980. p. 153-154.

575 GALVIS, Omar de Jesús Montilla; MARCHENA, Luis Guillermo Herrera. El deber ser de la auditoría. Estudios Gerenciales, Cali, n. 98, p. 83-110, ene./mar. 2006. p. 96.

576 Cf. BRASIL. Tribunal de Contas da União. Manual de auditoria operacional. 3. ed. Brasília: Tribunal de Contas da União, Secretaria de Fiscalização e Avaliação de Programas de Governo, 2010. Disponível em: https://portal.tcu.gov.br/controle-externo/normas-e-orientacoes/normas-de-fiscalizacao/auditoria-operacional.htm. Acesso em: 30 out. 2019; BRASIL. Tribunal de Contas da União. Padrōes de auditoria de conformidade: Portaria-Segecex n. 26, de 19 de outubro de 2009. Boletim do Tribunal de Contas da Uniáo: Especial, Brasília, a. XLIII, n. 2, 3 fev. 2010. Disponível em: https://portal.tcu.gov. $\mathrm{br} /$ controle-externo/normas-e-orientacoes/normas-de-fiscalizacao/auditoria-de-conformidade.htm. 


\section{-. Contas dos governantes}

Assim, na fase de planejamento de uma auditoria, conhecendo o objeto a ser auditado, o auditor tem a sua disposição o inventário de riscos e controles - ou outra denominação equivalente - como método de direcionar os esforços para questóes críticas. Selecionadas as questôes a analisar, é amplamente difundida a utilização das matrizes de planejamento para: (i) definir as informações que serão necessárias para realizar o trabalho e identificar onde obtê-las; (ii) prever, pormenorizadamente, quais os procedimentos e as tarefas a serem executados, bem como as técnicas de auditoria que deverão ser aplicadas, com vistas a obter as fontes de informação e analisar as informações necessárias a responder as questôes de auditoria; (iii) definir em que objetos cada procedimento de auditoria deve ser aplicado; e (iv) planejar qual integrante da equipe de auditoria será responsável pela execução de cada procedimento, em que momento e em cada objeto.

Tal matriz de planejamento é, obviamente, ferramenta a ser utilizada, também, na fase de execução da auditoria, funcionando como roteiro de execução, verdadeira garantia de que ela será executada metodicamente.

$\mathrm{Na}$ fase de execução, a matriz de achados - entre outros modelos que apoiam a aplicação das técnicas de auditoria - é relevante ferramenta que o profissional de auditoria governamental tem a sua disposição, para sistematizar o processo lógico de identificação de achados e de produção de propostas de encaminhamentos, recomendações e determinações pela equipe. Do mesmo modo, especialmente nas auditorias de regularidade, a matriz de responsabilização auxilia os auditores a evidenciarem a responsabilidade, de forma individualizada, pelas eventuais irregularidades ou ilegalidades verificadas.

$\mathrm{Na}$ fase de comunicação dos resultados, o relatório é elaborado a partir de modelos disponibilizados que são preenchidos com as informaçôes coletadas e registradas nas matrizes de achados e responsabilização.

Desse modo, como demonstrado nesta subseção, a sistematização é inerente aos trabalhos de auditoria governamental. Esse é, aliás, o motivo pelo qual tanto cada corte de contas como os organismos nacionais e internacionais que as congregam se esforçam para emitir normas, manuais e padrôes de auditoria, que regulem cada aspecto dessa atividade.

A inspeção, outro instrumento de fiscalização citado no inciso IV do artigo 71 da CRFB/1988, é utilizada pelos tribunais de contas para apurar fatos específicos, especialmente aqueles narrados em denúncias e representações, quando não há necessidade de efetuar um exame profundo e verticalizado de diversos aspectos do objeto auditado.

Acesso em: 30 out. 2019; DISTRITO FEDERAL (Brasil). Tribunal de Contas. Manual de auditoria: parte geral. 2. ed. Brasília: Tribunal de Contas do Distrito Federal, 2011; MINAS GERAIS. Tribunal de Contas do Estado. Resolução n. 2, de 27 de fevereiro de 2013. Aprova o Manual de Auditoria, institui o Comitê de Auditoria do Tribunal de Contas do Estado de Minas Gerais e dá outras providências. Belo Horizonte: Tribunal de Contas do Estado de Minas Gerais, 2013; e ESPÍRITO SANTO. Tribunal de Contas do Estado. Resolução n. 287, de 5 de maio de 2015. Aprova o Manual de auditoria de conformidade do Tribunal de Contas do Estado do Espírito Santo. Vitória: Tribunal de Contas do Estado do Espírito Santo, 2015. 
Essa especificidade e limitação do objeto da fiscalização é a principal diferença da inspeção em relação à auditoria. Não obstante, observando essa característica, os auditores de controle externo utilizam, tanto quanto possível, as técnicas e os modelos desenvolvidos para as auditorias, bem como observam, no que couber, as normas que lhes são aplicáveis.

Segundo Monique Menezes, o levantamento é o instrumento de fiscalização utilizado pelas cortes de contas "[...] para conhecer a organização e funcionamento dos órgãos da administração pública. Através deste instrumento, o TCU identifica as atividades a serem auditadas" ${ }^{\prime 57}$. É que, na fase de planejamento das auditorias, o conhecimento prévio do objeto a ser auditado - profundo o suficiente para a construção de uma visão geral sobre o objeto -, pelos profissionais de auditoria governamental envolvidos no trabalho, é premissa necessária para a utilização das ferramentas apropriadas à etapa, essenciais no desenrolar das demais fases. Do contrário, as ferramentas arroladas não funcionam.

Aí entram os levantamentos, com a função de conhecer o funcionamento das instituiçōes governamentais, processos, projetos, atividades ou programas de governo, usualmente com a avaliação profunda dos controles internos existentes nas instituições e em seus processos. Foram concebidos para subsidiar o planejamento das futuras fiscalizaçôes dos tribunais de contas, identificando fraquezas e riscos, indicando açôes, fatos ou objetos a serem fiscalizados e, inclusive, avaliando a viabilidade de realização de fiscalizaçōes.

Recentemente, deve-se destacar, esse instrumento tem sido utilizado para realização de grandes diagnósticos pelas cortes de controle externo, inclusive de âmbito nacional, com cooperação e coordenação entre as cortes de diversos entes federativos.

O acompanhamento é utilizado pelas cortes de contas para fiscalização concomitante. Por seu intermédio, como explica Monique Menezes, o tribunal de contas “[...] pode fazer visitas técnicas, participar de eventos promovidos pela instituição, obter informações de publicações oficiais, solicitar documentos, etc." 578 , com o objetivo de examinar, por um período, a legalidade, a legitimidade e a economicidade de determinada instituição pública. É intensamente utilizado na fiscalização da gestão fiscal, abordada na subseção seguinte deste trabalho.

Finalmente, pelo instrumento do monitoramento, as cortes de contas verificam o cumprimento de suas deliberaçôes e os resultados que daí advirem. A partir das determinações e recomendações emitidas pela decisão do tribunal, é utilizado para se verificar tanto o cumprimento das deliberações como os resultados delas advindos.

577 MENEZES, Monique. La expansión del control externo en Brasil: el Tribunal de Cuentas de La Unión. Desacatos, Ciudad de México, n. 49, p. 64-81, 2015. p. 74 (tradução nossa).

578 MENEZES, Monique. La expansión del control externo en Brasil: el Tribunal de Cuentas de La Unión. Desacatos, Ciudad de México, n. 49, p. 64-81, 2015. p. $74-75$ (tradução nossa). 


\section{-• Contas dos governantes}

Lucas Rocha Furtado ${ }^{579}$ acresce à lista apresentada, como instrumentos de fiscalização, a representação e a denúncia. Todavia, elas não são instrumentos de fiscalização, mas insumos para a fiscalização, que os tribunais de contas recebem no exercício de sua função de ouvidoria, tratada na subseção 2.6.2 (p. 132) deste trabalho.

\subsubsection{Fiscalização da gestão fiscal}

A LRF, emitida pelo Congresso Nacional, conforme ensina Fernando Facury Scaff ${ }^{580}$, para veicular normas gerais de direito financeiro, no exercício da competência atribuída pelo artigo 24, inciso I, da CRFB/1988, combinado com seu artigo 163, inciso $\mathrm{V}$, regulamentou o exercício da fiscalização da gestão fiscal pelas cortes de controle externo.

Em seu exercício, expressão da função fiscalizadora, as cortes de contas devem enfatizar, conforme o artigo 59 da LRF, a verificação do cumprimento (i) das metas estabelecidas na LDO; (ii) dos limites e condições para realização de operaçóes de crédito e inscrição em restos a pagar; (iii) das medidas adotadas para o retorno da despesa total com pessoal ao limite; (iv) das providências tomadas para recondução dos montantes das dívidas consolidada e mobiliária aos limites; (v) da destinação de recursos obtidos com a alienação de ativos; e (vi) do limite de gastos totais dos legislativos municipais.

Ao fiscalizarem a gestão fiscal, os tribunais de contas devem "[...] verificar os cálculos dos limites da despesa total com pessoal de cada Poder e órgão [...]"581, conforme estabelecido no $\$ 2^{\circ}$ do artigo 59 da CRFB/1988. Tal atividade não se restringe à conferência dos cálculos apresentados nos demonstrativos e verificação se eles são superiores aos limites estabelecidos. Analisam, também, a conformidade da metodologia empregada pela Administração, na elaboração de seus relatórios e demonstrativos, e examinam o conteúdo contabilizado em cada rubrica, com a verificação de sua adequação à metodologia adotada.

Além disso, de acordo com o artigo 59, $\$ 1^{\circ}$, da CRFB/1988, as cortes de controle externo devem emitir alerta quando constatarem (i) que a realização da receita poderá não comportar o cumprimento das metas de resultado primário ou nominal estabelecidas no Anexo de Metas Fiscais; (ii) que a despesa com pessoal ultrapassou

FURTADO, Lucas Rocha. Curso de direito administrativo. 5. ed. Belo Horizonte: Fórum, 2016. p. 971.

580 SCAFF, Fernando Facury. O que são normas gerais de direito financeiro? In: MARTINS, Ives Gandra da Silva; MENDES, Gilmar Ferreira; NASCIMENTO, Carlos Valder. Tratado de Direito Financeiro. v. 1. São Paulo: Saraiva, 2013. p. 39.

581 BRASIL. Lei Complementar n. 101, de 4 de maio de 2000. Estabelece normas de finanças públicas voltadas para a responsabilidade na gestão fiscal e dá outras providências. Diário Oficial da União, Brasília, a. CXXXVIII, n. 86, Seção 1, p. 1-9, 5 maio 2000. Disponível em: http://www.planalto.gov. br/ccivil_03/leis/LCP/Lcp101.htm. Acesso em: 31 out. 2019. 
90\% do limite; (iii) que as dívidas consolidada e mobiliária, as operações de crédito e a concessão de garantia se encontram acima de $90 \%$ dos limites; ou (iv) que os gastos com inativos e pensionistas ultrapassaram o limite definido em lei.

Como ensina Helio Saul Mileski, a responsabilidade “[...] pela gestão fiscal se fixa na pessoa do dirigente máximo dos Poderes Executivo, Legislativo e Judiciário, do Ministério Público e do Tribunal de Contas, sem admitir delegação de poderes [...]"582. Além desses, após a EC n. 45, de 30 de dezembro de 2004, por força do artigo $134, \$ 2$, da CRFB/1988, que garantiu às defensorias públicas a autonomia financeira, pode-se dizer que o seu dirigente máximo se soma aos indicados por Helio Saul Mileski, como gestor fiscal, sujeito à fiscalização da gestão fiscal efetuada pelos tribunais de contas.

Pelo exposto nesta subseção, verifica-se que a ampla função fiscalizadora das cortes de contas abrange a administração direta e a indireta de todos os poderes e órgãos independentes da Administração Pública. Além disso, pode-se afirmar que ela é multiforme, pois envolve a fiscalização dos atos sujeitos a registro, a fiscalização stricto sensu - com a utilização de auditorias, inspeções, levantamentos, acompanhamentos e monitoramentos - e a fiscalização da gestão fiscal.

\subsubsection{Função judicante}

Antes de discorrer sobre a função judicante dos tribunais de contas, tal como arrolada na classificação adotada de José Mauricio Conti, deve-se relembrar a ressalva registrada na subseção 2.5 .2 (p. 113) deste trabalho, segundo a qual, ao se referir à função judicante das cortes de controle externo, não se está a afirmar que eles detêm função jurisdicional. Como se afirma na subseção indicada, eles julgam administrativamente, como se julga um processo administrativo disciplinar, por exemplo.

Com atenção à ressalva, pode-se afirmar que a função judicante é exercida pelas cortes de contas com alicerce na competência atribuída pelo artigo 71, inciso II, da CRFB/1988. A competência para os tribunais de contas julgarem, prevista no dispositivo, pode ser dividida em ordinária e especial.

Segundo Jorge Ulisses Jacoby Fernandes, a competência de julgamento ordinária dos tribunais de contas “[...] se depreende da expressão julgar as contas dos administradores e demais responsáveis" ${ }^{83}$. Por força do dispositivo, não somente os administradores têm as contas julgadas pelas cortes de contas, mas, também, todos os demais responsáveis por dinheiros, bens e valores públicos da administração direta e indireta.

582 MILESKI, Helio Saul. O ordenador de despesa e a Lei de Responsabilidade Fiscal - conceituação e repercussões jurídicolegais. Interesse Público - IP, São Paulo, v. 4, n. 15, p. 67-82, jul./set. 2002. p. 75-76.

583 FERNANDES, Jorge Ulisses Jacoby. Tomada de contas especial: processo e procedimento na administração pública e nos tribunais de contas. 7. ed. Belo Horizonte: Fórum, 2017. p. 28. 
-. Contas dos governantes

Como destacou Emerson Cesar da Silva Gomes, ao comentar o arquétipo de accountability financeira e orçamentária desenhado pela CRFB/1988,

Optou-se, entre nós, por um modelo que privilegia a verificação regular e periódica das contas públicas, em geral anual, predominantemente sob o aspecto da legalidade e da legitimidade. Os gestores públicos são obrigados a submeter, assim, as prestações de contas para avaliação e julgamento dos Tribunais de Contas. Complementando este processo de julgamento das contas, existem as fiscalizações de natureza esporádica e seletiva, por critérios de amostragem, risco ou materialidade (ou outro critério relevante adotado pelos Tribunais de Contas ou por iniciativa do Parlamento) $)^{584}$.

De acordo com Helio Saul Mileski, embora, pelo hábito administrativo, seja comum sua utilização como sinônimos, a rigor, a expressão "administradores e demais responsáveis”, adotada pelo artigo 71, inciso II, da CRFB/1988, “[...] envolve responsabilidade mais ampla que a ordenação de despesas [...]" ${ }^{585}$. Como adverte, "[...] se poderia dizer que autoridade ou responsável por dinheiros, bens e valores públicos é gênero do qual ordenador de despesa é espécie" ${ }^{586}$.

Nos termos do artigo 80, $\$ 1^{\text {o }}$, do DL n. 200, de 25 de fevereiro de 1967, "Ordenador de despesas é tôda e qualquer autoridade de cujos atos resultarem emissão de empenho, autorização de pagamento, suprimento ou dispêndio de recursos da União ou pela qual esta responda" ${ }^{587}$. Assim, o ordenador de despesas, como ensina Helio Saul Mileski, “[...] é a autoridade administrativa, o responsável-mor, com poderes e competência para determinar ou não a realização da despesa, de cujo ato gerencial surge a obrigação de justificar o bom e o regular uso dos dinheiros públicos" $" 588$.

Logo, sendo administradores de recursos públicos, os ordenadores de despesas submetem-se à prestação e ao julgamento de suas contas perante os tribunais de contas, conforme o artigo 71, inciso II, da CRFB/1988.

Como enumera Helio Saul Mileski, "Ostentam a condição de Ordenadores de Despesa originários os Presidentes dos Poderes Legislativo e Judiciário, os Ministros e

584 GOMES, Emerson Cesar da Silva. Responsabilidade financeira: uma teoria sobre a responsabilidade no âmbito dos tribunais de contas. 2009. 379 f. Dissertação (Mestrado em Direito) - Departamento de Direito Econômico, Financeiro e Tributário, Faculdade de Direito, Universidade de São Paulo, São Paulo, 2009. f. 50-51.

585 MILESKI, Helio Saul. O ordenador de despesa e a Lei de Responsabilidade Fiscal - conceituação e repercussões jurídicolegais. Interesse Público - IP, São Paulo, v. 4, n. 15, p. 67-82, jul./set. 2002. p. 75.

586 MILESKI, Helio Saul. O controle da gestão pública. 3. ed. Belo Horizonte: Fórum, 2018. p. 162.

587 BRASIL. Decreto-Lei n. 200, de 25 de fevereiro de 1967. Dispõe sôbre a organização da Administração Federal, estabelece diretrizes para a Reforma Administrativa e dá outras providências. Diário Oficial da União, Brasília, 27 fev. 1967. Disponível em: http://www.planalto.gov.br/ccivil_03/decreto-lei/ Del0200.htm. Acesso em: 31 out. 2019.

588 MILESKI, Helio Saul. O ordenador de despesa e a Lei de Responsabilidade Fiscal - conceituação e repercussões jurídicolegais. Interesse Público - IP, São Paulo, v. 4, n. 15, p. 67-82, jul./set. 2002. p. 69. 
Secretários de Estado, assim como os dirigentes" ${ }^{589}$ da administração indireta. Segundo ele, os chefes de Poder Executivo não podem ser considerados ordenadores de despesa.

Tal questão é controversa e, como envolve a competência para a emissão de parecer prévio, objeto específico deste trabalho, é analisada adiante, na subseção 3.3.1 (p. 223). Do mesmo modo, a controvérsia a respeito da instituição competente, em cada esfera, para o julgamento das contas dos dirigentes das casas legislativas, do Poder Judiciário, dos ministérios públicos, das defensorias públicas e das cortes de contas, acirrada em razão do que previram o artigo 56 da LRF e algumas emendas a constituições estaduais, como envolve a competência para a emissão de parecer, é analisada adiante, na subseção 3.3 .3 (p. 281).

Além dos ordenadores de despesa, a expressão "administradores e demais responsáveis", que dá contornos à competência prevista no inciso II do artigo 71 da CRFB/1988, abrange todos os que exercem “[...] atividades de arrecadação da receita, realização da despesa ou administração de dinheiros, bens e valores públicos [...]" ${ }^{\prime 290}$, sujeitando-os à prestação periódica de contas perante as cortes de controle externo, que são competentes para o seu julgamento. Por conseguinte, a extensão subjetiva da função judicante das cortes de contas vai além dos ordenadores de despesa.

A apreciação das contas ordinárias anuais, como ensina Odete Medauar, é realizada "[...] com base em levantamentos contábeis, certificados de auditoria, pronunciamentos das autoridades administrativas e inspeçóes" ${ }^{591}$. Observa-se, portanto, que as informações geradas no exercício da função fiscalizadora dos tribunais de contas, abordada na subseção 2.6.7 (p. 146) deste trabalho, constituem insumo para as atividades envolvidas na sua função judicante. Por isso, Isaias Lopes da Cunha destaca que "[...] as competências de fiscalizar e julgar [...] são fundamentais e indispensáveis para eficácia do controle externo. Uma não se sobrepõe a outra, pelo contrário, a primeira, na maioria das vezes, instrui e subsidia a segunda"592.

De acordo com Jorge Ulisses Jacoby Fernandes, enquanto as contas ordinárias "[...] dão um apanhado da aplicação e movimentação de todos os bens e recursos públicos geridos pelo órgão", a competência de julgamento dita especial "[...] se depreende da expressão julgar as contas daqueles que deram causa a perda, extravio ou outra ir-

589 MILESKI, Helio Saul. O ordenador de despesa e a Lei de Responsabilidade Fiscal - conceituação e repercussōes jurídicolegais. Interesse Público - IP, São Paulo, v. 4, n. 15, p. 67-82, jul./set. 2002. p. 70.

590 MILESKI, Helio Saul. O ordenador de despesa e a Lei de Responsabilidade Fiscal - conceituação e repercussões jurídicolegais. Interesse Público - IP, São Paulo, v. 4, n. 15, p. 67-82, jul./set. 2002. p. 72.

591 MEDAUAR, Odete. Controle da administração pública pelo tribunal de contas. Revista de Informação Legislativa, Brasília, v. 27, n. 108, p. 101-126, out./dez. 1990. p. 120-121.

${ }^{592}$ CUNHA, Isaias Lopes da. A auditoria contábil financeira e o julgamento das contas públicas. In: LIMA, Luiz Henrique; OLIVEIRA, Weder de; CAMARGO, João Batista (Coord.). Contas governamentais e responsabilidade fiscal. Belo Horizonte: Fórum, 2017. p. 263. 


\section{-• Contas dos governantes}

regularidade de que resulte prejuízo ao erário" ${ }^{593}$. Assim, ainda que não sejam administradores ou responsáveis por dinheiros, bens e valores públicos, devem ter suas contas tomadas e julgadas de forma especial, pelas cortes de contas, os que tenham dado causa a perda, extravio ou outra irregularidade de que resulte prejuízo ao erário.

Vale destacar que aqueles que se encontrarem nessa situação devem ter as contas julgadas ainda que não façam parte da Administração Pública. Dessa maneira, até agentes privados podem ter suas contas julgadas pelas cortes de controle externo, desde que, como ensina Jorge Ulisses Jacoby Fernandes ${ }^{594}$, haja conluio com agente público.

Por outro lado, é controversa a competência para o julgamento das contas dos chefes de Poder Executivo que, eventualmente, deem causa a perda, extravio ou outra irregularidade de que resulte prejuízo ao erário. Essa celeuma, como também envolve a competência para a emissão de parecer prévio, objeto específico deste trabalho, é analisada adiante, na subseção 3.3.1 (p. 223).

Tanto no caso das prestações ou tomadas de contas anuais, ordinárias, como no caso das tomadas de contas especiais, considerando a redação do inciso II do artigo 71 da CRFB/1988, pode-se dizer que os tribunais de contas julgam - não no sentido jurisdicional, como já destacado - as contas, não os responsáveis pela sua apresentação.

Nesse sentido, Alfredo Buzaid afirmava que "O Tribunal de Contas julga as contas, não os responsáveis, que ficam sujeitos à jurisdição criminal”595 e José Cretella Júnior ensina que “[...] o Tribunal de Contas 'aprecia', 'fiscaliza' ou 'julga' contas, ao passo que o Poder Judiciário julga pessoas" ${ }^{596}$. Ao concordar com os autores referidos, Jorge Ulisses Jacoby Fernandes destaca que "[...] não há como dizer que uma conta é irregular sem identificar a causa da irregularidade e o agente responsável. Sem esses elementos, não há como garantir a ampla defesa e o contraditório" ${ }^{597}$.

Deve-se ter em mente que o julgamento pela irregularidade, rejeição ou reprovação das contas, como demonstra a subseção 2.6 .5 (p. 140), não é sanção jurídica. Contudo, conforme ali se explica, por força do artigo 71, inciso VIII, da CRFB/1988, pode ensejar a aplicação de sanções, aos responsáveis pelas contas, pelas cortes de controle externo.

Independentemente das sanções que possam o acompanhar, o juízo negativo sobre as contas produz efeitos sobre accountability financeira e orçamentária da Admi-

593 FERNANDES, Jorge Ulisses Jacoby. Tomada de contas especial: processo e procedimento na administração pública e nos tribunais de contas. 7. ed. Belo Horizonte: Fórum, 2017. p. 28-29.

594 FERNANDES, Jorge Ulisses Jacoby. Tomada de contas especial: processo e procedimento na administração pública e nos tribunais de contas. 7. ed. Belo Horizonte: Fórum, 2017. p. 117.

595 BUZAID, Alfredo. O tribunal de contas no Brasil. Revista da Faculdade de Direito da Universidade de São Paulo, São Paulo, v. 62, n. 2, p. 37-62, 1967. p. 53.

596 CRETELLA JÚNIOR, José. Natureza das decisões do tribunal de contas. Revista de Direito Administrativo, Rio de Janeiro, v. 166, p. 1-16, out./dez. 1986. p. 12-13.

597 FERNANDES, Jorge Ulisses Jacoby. Tribunais de contas do Brasil: jurisdição e competência. 4. ed. Belo Horizonte: Fórum, 2016. p. 341. 
nistração, na medida em que comunica claramente a outros agentes de accountability, a existência de problemas na gestão financeira e orçamentária a cargo de seu responsável. Assim, no âmbito da accountability vertical, os resultados de julgamentos de contas podem influenciar as decisões dos eleitores, nas próximas eleiçôes, sobre em quem depositar o seu voto.

No âmbito da accountability horizontal, por sua vez, o julgamento pela irregularidade das contas de determinado agente público, a depender da situação que a ocasionou, pode resultar, por exemplo: na instituição de comissão parlamentar de inquérito, pela casa legislativa respectiva; na propositura de ação de improbidade administrativa, pelo ministério público competente; ou na ação de impugnação de registro de candidatura, por candidato, partido político, coligação ou pelo ministério público eleitoral competente.

Quanto ao último exemplo, vale destacar que, em razão do artigo $1^{\circ}$, inciso $\mathrm{I}$, alínea "g", da LC n. 64, de 18 de maio de 1990, com redação dada pela LC n. 135, de 4 de junho de 2010, conhecida como Lei da Ficha Limpa, os que tiverem suas contas rejeitadas pelos tribunais de contas, em razão de irregularidade insanável que configure ato doloso de improbidade administrativa, são inelegíveis por oito anos para qualquer cargo público.

Dessa forma, a função judicante adquiriu especial relevo à medida que pode refletir na elegibilidade daqueles que vêm suas contas julgadas, embora, como observa Emerson Cesar da Silva Gomes ${ }^{598}$, dependa a consequente declaração da inelegibilidade, sempre, de decisão da justiça eleitoral. De todo o modo, como assevera Jorge Ulisses Jacoby Fernandes “[...] a elaboração da lista dos agentes que tiveram suas contas rejeitadas em processo de restriçãao das inscrições para cargo eletivo" ${ }^{\prime 299}$ tem fundamental importância para o aperfeiçoamento do regime democrático. Assim, constitui atribuição que não pode ser descuidada pelas cortes de contas.

Desse modo, conforme apresenta esta subseção, os tribunais de contas, no exercício da função judicante, têm competência para julgar as contas não somente dos ordenadores de despesa, mas - com exceção dos presidentes da República, governadores de estado e do DF e prefeitos municipais - de todos administradores e demais responsáveis por dinheiros, bens e valores públicos, tanto no âmbito da administração direta como da indireta. O juízo negativo sobre as contas, além de repercussóes diversas nas dimensões horizontal e vertical da accountability, pode ser acompanhado de sanções, na forma apresentada na subseção 2.6.5 (p. 140) deste trabalho.

598 GOMES, Emerson Cesar da Silva. Responsabilidade financeira: uma teoria sobre a responsabilidade no âmbito dos tribunais de contas. 2009. 379 f. Dissertação (Mestrado em Direito) - Departamento de Direito Econômico, Financeiro e Tributário, Faculdade de Direito, Universidade de São Paulo, São Paulo, 2009. f. 33-34.

599 FERNANDES, Jorge Ulisses Jacoby. Tribunais de contas do Brasil: jurisdição e competência. 4. ed. Belo Horizonte: Fórum, 2016. p. 412. 


\section{-. Contas dos governantes}

\subsubsection{Função consultiva}

Entre as funções dos tribunais de contas, este trabalho, propositalmente, deixa por último a análise da função consultiva. Ela engloba o exame das consultas formalmente formuladas pelas autoridades administrativas legitimadas, a respeito de dúvidas na aplicação de dispositivos legais e regulamentares relativas às áreas de atuação das cortes de controle externo, e a competência prevista no inciso I do artigo 71 da CRFB/1988.

A competência para o exame de consultas, pelas cortes de contas, não é prevista na CRFB/1988, motivo pelo qual não é objeto de maiores considerações neste traba1 ho ${ }^{600}$. Convém dizer, porém, que sua origem é legal, sendo comumente prevista nas leis orgânicas dos tribunais de contas - a exemplo do artigo $1^{\circ}$, inciso XVII, da Lei Orgânica do TCU -, e que são utilizadas, pelas cortes de controle externo, para orientar as unidades administrativas sujeitas à sua competência, a respeito de como elas interpretam determinadas normas, e, com isso, diminuir a incerteza e a insegurança jurídica sobre o modo como as aplicarão na análise dos casos concretos que, eventualmente, lhes sejam submetidos.

Além da resposta às consultas, a função consultiva abrange a competência prevista no inciso I do artigo 71 da CRFB/1988. Assim, é no exercício dessa função que as cortes de contas apreciam as contas prestadas anualmente por presidentes da República, governadores de estado e do DF e prefeitos municipais, e emitem parecer prévio a seu respeito. Como o objeto da pesquisa sobre a qual se disserta neste trabalho é, justamente, a apreciação, pelos tribunais de contas do Brasil, no exercício da função consultiva, das contas anualmente prestadas por chefes de Poder Executivo, ao invés de examinar tal função nesta subseção, todo o próximo capítulo é dedicado a ela.

Ante todo o exposto neste capítulo, percebe-se que, enquanto o primeiro capítulo (p. 39) deste trabalho demonstra que os governantes devem se sujeitar à accountability em todos os ramos em que atuem, inclusive em relação à gestão financeira e orçamentária da Administração Pública, neste traçam-se as linhas gerais do sistema constitucional de accountability financeira e orçamentária.

Tendo em conta suas seções 2.1 (p. 77) e 2.2 (p. 82), conclui-se que os tipos de fiscalização - contábil, financeira, orçamentária, operacional e patrimonial - constituem um leque de opções à disposição das agências de accountability financeira e orçamentária da Administração Pública, que, no exercício do controle, devem ter em

600 A respeito das consultas dirigidas aos tribunais de contas, cf. FERNANDES, Jorge Ulisses Jacoby. Tribunais de contas do Brasil: jurisdição e competência. 4. ed. Belo Horizonte: Fórum, 2016. p. 324-328. Para uma visão diferente, da consulta como expressão da função normativa das cortes de contas, cf. ROSILHO, André Janjácomo. Controle da administração pública pelo Tribunal de Contas da União. 2016. 358 f. Tese (Doutorado em Direito) - Departamento de Direito do Estado, Faculdade de Direito, Universidade de São Paulo, São Paulo, 2016. f. 129-136. 
conta os aspectos da legalidade, da legitimidade e da economicidade. Posicionam-se os agentes de accountability financeira e orçamentária entre controle interno e externo Poder Legislativo e cortes de contas -, conforme estejam localizados, respectivamente, dentro ou fora da estrutura do agente controlado, conforme seçôes 2.3 (p. 89) e 2.4 (p. 97) deste trabalho.

A atuação dos trinta e três tribunais de contas brasileiros - órgãos independentes que auxiliam os parlamentos no exercício do controle externo, mas a eles não se subordinam - sujeita-se às normas de direito financeiro e se desenvolve administrativamente, em sede de processo administrativo de controle externo, como apresentam a seção 2.5 (p. 104) e suas subseções. Não obstante tal atuação esteja sujeita à influência de diversas normas, oriundas de fontes normativas diversas, em todas as esferas da federação, é a própria CRFB/1988 que lhes atribui uma série de competências, organizadas em torno das funções administrativa, de ouvidoria, normativa, corretiva, sancionadora, reintegradora, informativa, fiscalizadora, judicante e consultiva, como se expõe na seção 2.6 (p. 128) deste trabalho, e em suas subseções.

Observa-se, portanto, que este segundo capítulo faz a ligação entre os capítulos 1 (p. 39) e 3 (p. 165) deste trabalho. Permite a conexão da obrigação geral de sujeição dos governantes à accountability com o exame minucioso da prestação e apreciação, pelas cortes de controle externo, das contas prestadas por presidentes, governadores e prefeitos.

A partir dele, verifica-se, no próximo capítulo deste trabalho, como deve ser realizada a apreciação, pelos tribunais de contas do Brasil, das contas prestadas por chefes de Poder Executivo e se a legislação infraconstitucional, relacionada à apreciação dessas contas, atende normativamente ao exigido pelo sistema constitucional de accountability financeira e orçamentária. 